San Jose State University

SJSU ScholarWorks

Master's Theses

Master's Theses and Graduate Research

1993

\title{
The role of radar in the Pacific Theater during World War II : deployment, acceptance and effect
}

Paul Van Cozens

San Jose State University

Follow this and additional works at: https://scholarworks.sjsu.edu/etd_theses

\section{Recommended Citation}

Cozens, Paul Van, "The role of radar in the Pacific Theater during World War II : deployment, acceptance and effect" (1993). Master's Theses. 529.

DOI: https://doi.org/10.31979/etd.5vyd-2vas

https://scholarworks.sjsu.edu/etd_theses/529

This Thesis is brought to you for free and open access by the Master's Theses and Graduate Research at SJSU ScholarWorks. It has been accepted for inclusion in Master's Theses by an authorized administrator of SJSU ScholarWorks. For more information, please contact scholarworks@sjsu.edu. 


\section{INFORMATION TO USERS}

This manuscript has been reproduced from the microfilm master. UMI films the text directly from the original or copy submitted. Thus, some thesis and dissertation copies are in typewriter face, while others may be from any type of computer printer.

The quality of this reproduction is dependent upon the quality of the copy submitted. Broken or indistinct print, colored or poor quality illustrations and photographs, print bleedthrough, substandard margins, and improper alignment can adversely affect reproduction.

In the unlikely event that the author did not send UMI a complete manuscript and there are missing pages, these will be noted. Also, if unauthorized copyright material had to be removed, a note will indicate the deletion.

Oversize materials (e.g., maps, drawings, charts) are reproduced by sectioning the original, beginning at the upper left-hand corner and continuing from left to right in equal sections with small overlaps. Each original is also photographed in one exposure and is included in reduced form at the back of the book.

Photographs included in the original manuscript have been reproduced xerographically in this copy. Higher quality $6 "$ x 9 " black and white photographic prints are available for any photographs or illustrations appearing in this copy for an additional charge. Contact UMI directly to order.

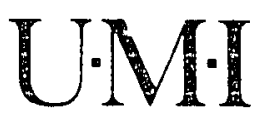

University Microfilms Internatıonal

A Bell \& Howell Information Company 300 North Zeeb Road. Ann Arbor. MI 48106-1346 USA $313: 761-4700 \quad 800: 521.0600$ 

Order Number 1353006

The role of radar in the Pacific theater during World War II: Deployment, acceptance and effect

\author{
Cozens, Paul Van, M.S.
}

San Jose State University, 1993

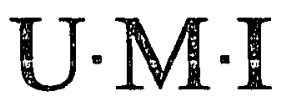

300 N. Zeeb Rd.

Ann Arbor, MI 48106 

The Role of Radar in the Pacific Theater

During World War II: Deployment, Acceptance and Effect

\author{
A Thesis \\ Presented to \\ The Faculty of the Department of History \\ San Jose State University
}

In Partial Fulfillment

of the Requirements for the Degree

Master of Science

by

Paul Van Cozens

May, 1993 


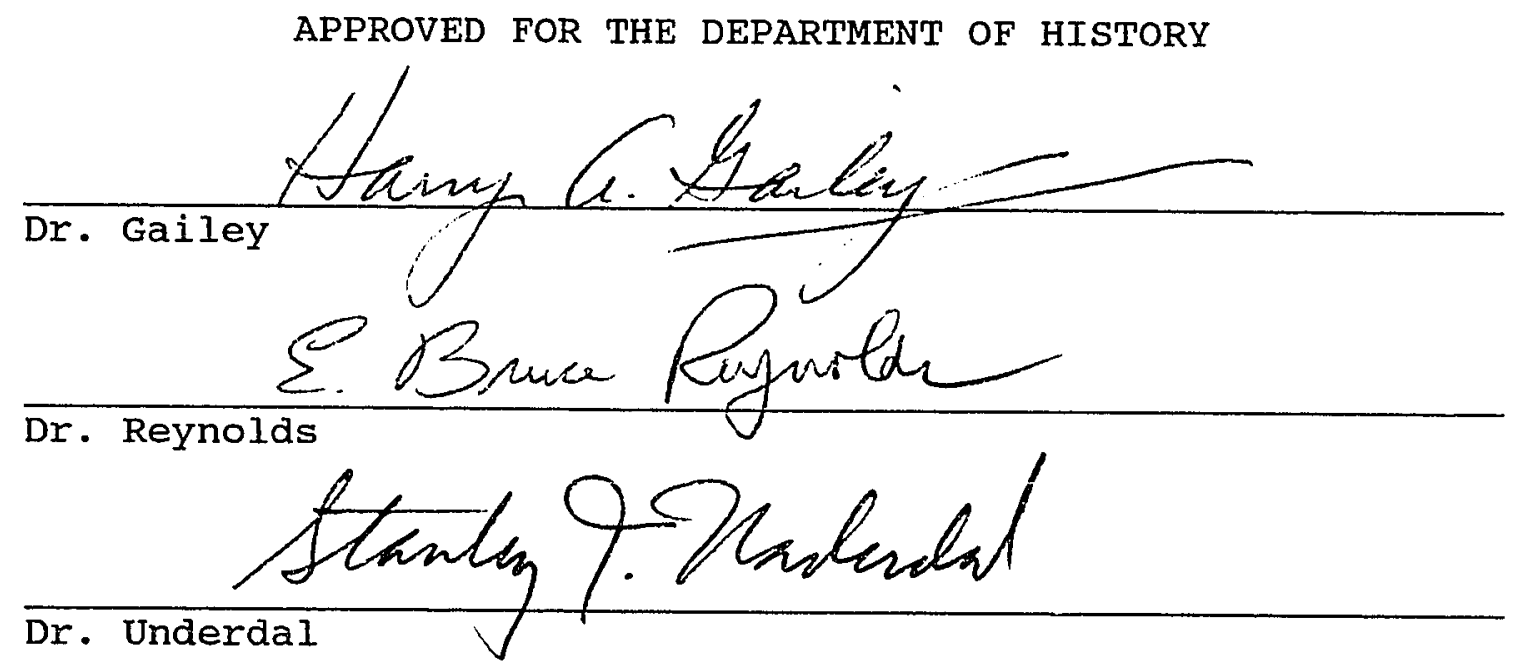

APPROVED FOR THE UNIVERSITY

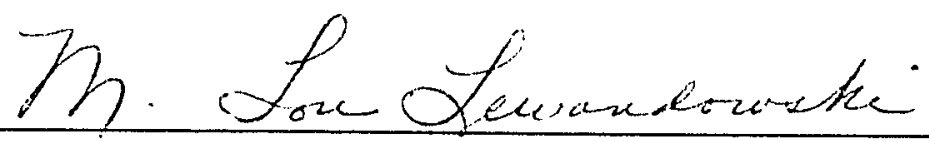




\section{ABSTRACT}

The Role of Radar in the Pacific Theater

During World War II: Deployment, Acceptance and Effect

by Paul V. Cozens

This thesis addresses the problems of radar's deployment, acceptance, and its effect on the outcome of combat in the Pacific theater during World War II. It examines the development of the electronic phenomenon from a physics laboratory experiment into a powerful weapon of war during a time of crisis.

The development of the electronics was accelerated by combat expediency, but acceptance of the electronic technology was often slow, because of a resistance to change from what is known to what is unkrown. Once the commanders in the field of battle learned to trust the electronics, the advantage in battle provided the Allies with the edge needed to win. 


\section{ACKNOWLEDGEMENTS}

A special thanks to the faculty of the San Jose state University History Department, specifically, Professor Harry A. Gailey, Jr., Professor E. Bruce Reynolds, Professor Stanley J. Underdal, Professor Joseph A. Boudreau and Clerical Assistant, Guy Wilson. 
Table of contents

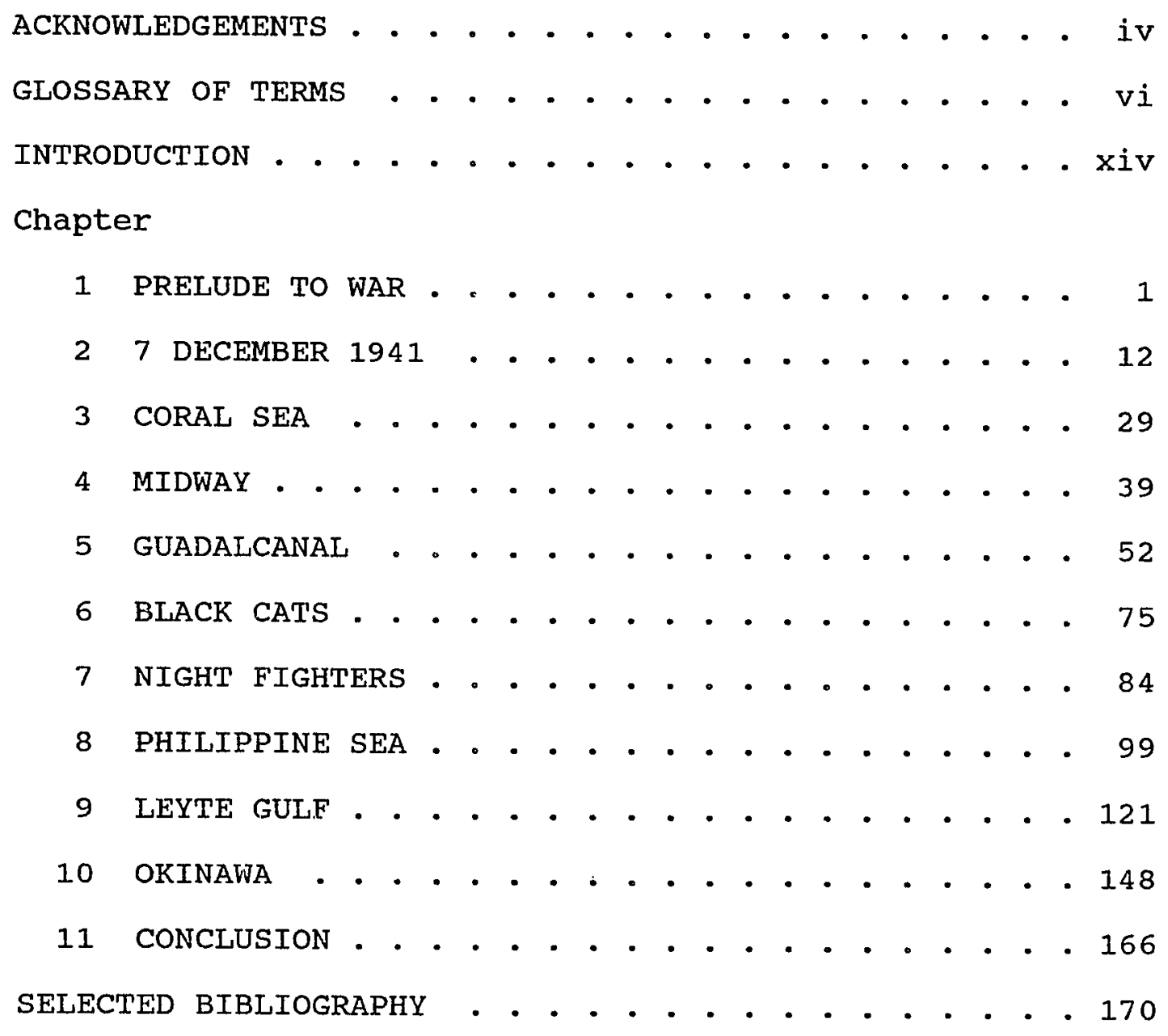


GLOSSARY of TERMS

Aircraft: Code Name

\section{Designation Manufacturer Descriptive Detail}

AIRCOBRA

P-39A Bell

USAAF, land-based, single-engined, fighter

\begin{tabular}{|c|c|c|c|}
\hline & $P-400$ & Bell & Export version \\
\hline AVENGER & $\mathrm{TBF}-1$ & Grumman & $\begin{array}{l}\text { USN, carrier- } \\
\text { based, single- } \\
\text { engined, torpedo } \\
\text { bomber }\end{array}$ \\
\hline & TBM-1 & General Motors & $\begin{array}{l}\text { Under license from } \\
\text { Grumman }\end{array}$ \\
\hline BEAUFIGHTER & $M K-I F$ & Bristol & $\begin{array}{l}\text { RAF, land-based, } \\
\text { twin-engined, } \\
\text { radar-equipped, } \\
\text { night fighter }\end{array}$ \\
\hline BETTY & G4M1 & Mitsubishi & $\begin{array}{l}\text { IJN, land-based, } \\
\text { twin-engined, } \\
\text { torpedo bomber }\end{array}$ \\
\hline BLACK WIDOW & $P-61 B$ & Northrup & $\begin{array}{l}\text { USAAF, land-based, } \\
\text { twin-engined, } \\
\text { radar-equipped, } \\
\text { night fighter }\end{array}$ \\
\hline BOSTON & $\mathrm{p}-70$ & Douglas & $\begin{array}{l}\text { USAAF, land-based, } \\
\text { twin-engined, } \\
\text { radar-equipped, } \\
\text { night fighter }\end{array}$ \\
\hline BUFFALO & $F 2 A-1$ & Brewster & $\begin{array}{l}\text { USN, carrier-based, } \\
\text { single-engined, } \\
\text { fighter }\end{array}$ \\
\hline
\end{tabular}

vi 


\begin{tabular}{|c|c|c|c|}
\hline CATALINA & PBY & Consolidated & $\begin{array}{l}\text { USN, (amphibious) } \\
\text { twin-engined, } \\
\text { patrol-flying boat- } \\
\text { bomber }\end{array}$ \\
\hline CLAUDE & A $5 \mathrm{M} 4$ & Mitsubishi & $\begin{array}{l}\text { IJN, carrier-based, } \\
\text { single-engined, } \\
\text { fighter, with fixed } \\
\text { landing gear and an } \\
\text { open cockpit }\end{array}$ \\
\hline \multirow[t]{2}{*}{ CORSAIR } & $F 4 U-1$ & Chance-Vought & $\begin{array}{l}\text { USN, carrier-based, } \\
\text { single-engined, } \\
\text { fighter }\end{array}$ \\
\hline & $\mathrm{F} 4 \mathrm{U}-1(\mathrm{~N})$ & & $\begin{array}{l}\text { USN, carrier-based, } \\
\text { radar-equipped, } \\
\text { night fighter }\end{array}$ \\
\hline CONDOR & Fw200c & Focke wulf & $\begin{array}{l}\text { GER, land-based, } \\
\text { four-engined, patrol } \\
\text { bomber }\end{array}$ \\
\hline \multirow[t]{2}{*}{ DAKOTA } & $c-47$ & Douglas & $\begin{array}{l}\text { USAAF, land-based, } \\
\text { twin-engined, cargo }\end{array}$ \\
\hline & $R-4 D$ & & $\begin{array}{l}\text { USN, land-based, } \\
\text { twin-engined, } \\
\text { version of the } c-47\end{array}$ \\
\hline DAUNTLESS & SBD -3 & Douglas & $\begin{array}{l}\text { USN, carrier-based, } \\
\text { single-engined, dive } \\
\text { bomber }\end{array}$ \\
\hline DEFIANT & $M K-I$ & Boulton-Paul & $\begin{array}{l}\text { RAF, land-based, } \\
\text { single-engined, } \\
\text { fighter }\end{array}$ \\
\hline DEVASTATOR & TBD-1 & Douglas & $\begin{array}{l}\text { USN, carrier-based, } \\
\text { single-engined, } \\
\text { torpedo bomber }\end{array}$ \\
\hline EMILY & H8K2 & Kawanishi & $\begin{array}{l}\text { IJN, four-engined, } \\
\text { patrol-flying boat- } \\
\text { bomber }\end{array}$ \\
\hline FLYING FORTRESS & $B-17 E$ & Boeing & $\begin{array}{l}\text { USAAF, land-based, } \\
\text { four-engined, heavy } \\
\text { bomber }\end{array}$ \\
\hline
\end{tabular}

vii 


\begin{tabular}{|c|c|c|c|}
\hline FRANCIS & P1YI & Yokosuka & $\begin{array}{l}\text { IJN, land-based, } \\
\text { twin-engined, } \\
\text { medium bomber }\end{array}$ \\
\hline GEORGE & N1K2 & Kawanishi & $\begin{array}{l}\text { IJN, carrier-based, } \\
\text { single-engined, } \\
\text { fighter }\end{array}$ \\
\hline HAVOC & MK-II & Douglas & $\begin{array}{l}\text { RAF, land-based, } \\
\text { twin-engined, } \\
\text { lend-lease attack } \\
\text { bomber }\end{array}$ \\
\hline \multirow[t]{2}{*}{ HELLCAT } & $F 6 F-4$ & Grumman & $\begin{array}{l}\text { USH, carrier- } \\
\text { based, single- } \\
\text { engined, fighter }\end{array}$ \\
\hline & F6F-4( & & $\begin{array}{l}\text { USN, carrier- } \\
\text { based, single- } \\
\text { engined, radar- } \\
\text { equipped, night } \\
\text { fighter }\end{array}$ \\
\hline HELLDIVER & SB2C & Curtiss & $\begin{array}{l}\text { USN, carrier-based, } \\
\text { single-engined, dive } \\
\text { bomber }\end{array}$ \\
\hline HURRICANE & $M K-I$ & Hawker & $\begin{array}{l}\text { RAF, land-based, } \\
\text { single-engined, } \\
\text { fighter }\end{array}$ \\
\hline JILL & $\mathrm{B} 6 \mathrm{~N} 2$ & Nakajima & $\begin{array}{l}\text { IJN, carrier-based, } \\
\text { twin-engined, } \\
\text { torpedo bomber }\end{array}$ \\
\hline JUDY & D4Y 1 & Yokosuka & $\begin{array}{l}\text { IJN, carrier-based, } \\
\text { single-engined, dive } \\
\text { bomber }\end{array}$ \\
\hline KATE & B5N2 & Nakajima & $\begin{array}{l}\text { IJN, carrier-based, } \\
\text { single-engined, } \\
\text { torpedo bomber }\end{array}$ \\
\hline LIGHTNING & $P-38$ & Lockheed & $\begin{array}{l}\text { USAAF, Iand-based, } \\
\text { twin-engined, } \\
\text { fighter with a twin- } \\
\text { boom tail }\end{array}$ \\
\hline
\end{tabular}




\begin{tabular}{|c|c|c|c|}
\hline LIBERATOR & $B-24$ & Consolidated & $\begin{array}{l}\text { USAAF, land-based, } \\
\text { four-engined, heavy } \\
\text { bomber }\end{array}$ \\
\hline MARINER & PBM & Martin & $\begin{array}{l}\text { USN, (amphibious) } \\
\text { twin-engined, } \\
\text { patrol-flying boat } \\
\text { bomber }\end{array}$ \\
\hline MAVIS & H6K5 & Kawanishi & $\begin{array}{l}\text { IJN, four-engined, } \\
\text { patrol-flying boat } \\
\text { bomber }\end{array}$ \\
\hline MITCHELL & $B-25$ & North American & $\begin{array}{l}\text { USAAF, land-based, } \\
\text { twin-engined, medium } \\
\text { bomber }\end{array}$ \\
\hline MARAUDER & $B-26$ & Martin & $\begin{array}{l}\text { USAAF, land-based, } \\
\text { twin-engined, medium } \\
\text { bomber }\end{array}$ \\
\hline MUSTANG & $P-51 D$ & North American & $\begin{array}{l}\text { USAAF, land-based, } \\
\text { single-engined, } \\
\text { fighter }\end{array}$ \\
\hline NELL & G3M2 & Mitsubishi & $\begin{array}{l}\text { IJN, land-based, } \\
\text { twin-engined, } \\
\text { medium bomber, } \\
\text { torpedo }\end{array}$ \\
\hline OKA & MXY7 & Yokosuka & $\begin{array}{l}\text { IJN, rocket powered } \\
\text { glide bomb, suicide } \\
\text { pilot controlled }\end{array}$ \\
\hline PETE & F2M1 & Mitsubishi & $\begin{array}{l}\text { IJN, single-engined, } \\
\text { float-observation } \\
\text { biplane fighter }\end{array}$ \\
\hline RUFE & $\mathrm{A} 6 \mathrm{M} 2-\mathrm{N}$ & Nakajima & $\begin{array}{l}\text { IJN, single-engined } \\
\text { float fighter (float } \\
\text { equipped Zero) }\end{array}$ \\
\hline SEAGULL & SOC-1 & Curtiss & $\begin{array}{l}\text { USN, single-engined, } \\
\text { float-observation } \\
\text { catapult biplane }\end{array}$ \\
\hline SUNDERLAND & $\mathrm{MK}-\mathrm{V}$ & Short & $\begin{array}{l}\text { RNAF, four-engined, } \\
\text { patrol-flying boat } \\
\text { bomber }\end{array}$ \\
\hline
\end{tabular}




\begin{tabular}{|c|c|c|c|}
\hline SUPER FORTRESS & $B-29$ & Boeing & $\begin{array}{l}\text { USAAF, land-based, } \\
\text { four-engined, heavy } \\
\text { bomber }\end{array}$ \\
\hline TABBY & L2D2 & Showa/Nakajima & $\begin{array}{l}\text { IJA, land-based, } \\
\text { twin-engined, } \\
\text { utility-cargo plane }\end{array}$ \\
\hline TIGERCAT & $F 7 F-2 N$ & Grumman & $\begin{array}{l}\text { USN, carrier-based, } \\
\text { twin-engined, radar } \\
\text { equipped night } \\
\text { fighter }\end{array}$ \\
\hline VAL & D3AI & Aichi & $\begin{array}{l}\text { IJN, carrier-based, } \\
\text { single-engined, dive } \\
\text { bomber with fixed } \\
\text { (spatted) landing } \\
\text { gear }\end{array}$ \\
\hline VINDICATOR & SB2U & Chance-Vought & $\begin{array}{l}\text { USN, carrier-based, } \\
\text { single-engined, dive } \\
\text { bomber }\end{array}$ \\
\hline \multirow[t]{2}{*}{ WILDCAT } & $\mathrm{F} 4 \mathrm{~F}-3$ & Grumman & $\begin{array}{l}\text { USN, carrier-based, } \\
\text { single-engined, } \\
\text { fighter with non- } \\
\text { folding wings }\end{array}$ \\
\hline & $\mathrm{F} 4 \mathrm{~F}-4$ & & $\begin{array}{l}\text { USN, carrier-based, } \\
\text { single-engined, } \\
\text { fighter with folding } \\
\text { wings }\end{array}$ \\
\hline ZEKE & $A 6 M-3$ & Mitsubishi & $\begin{array}{l}\text { IJN, carrier-based, } \\
\text { single-engined, } \\
\text { fighter (Official } \\
\text { Code Name for Zero) }\end{array}$ \\
\hline ZERO & $\mathrm{A} 6 \mathrm{M}-3$ & Mitsubishi & $\begin{array}{l}\text { IJN, carrier-based, } \\
\text { single-engined, } \\
\text { fighter }\end{array}$ \\
\hline
\end{tabular}


Key to United States Navy Aircraft Designations:

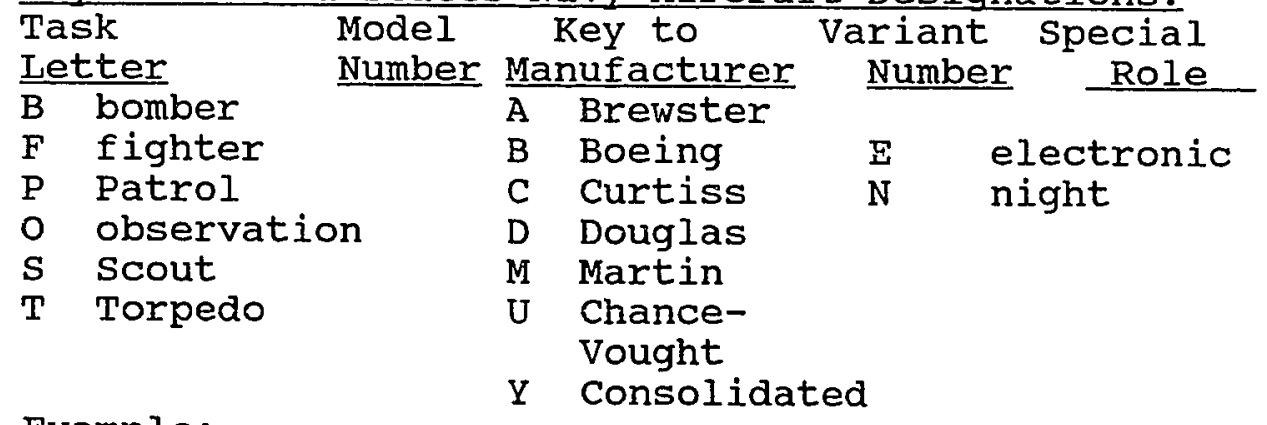

Example:

F4F3 (Fighter, 3rd model, Grumman, 3rd variant)

PBY-5 (Patrol Bomber, 1st model, Consolidated, 5th variant)

Note: (Model numbers indicated a specific design while the variant number indicated a significant change to the basic design but not significant enough to require a new model number)

(The F4F-3 was the fourth fighter model produced by Grumman. The -3 was the $3 \mathrm{rd}$ modification to the basic aircraft design. The F4F-3 had wings that did not fold. The next variant, the $\mathrm{F} 4 \mathrm{~F}-4$ had folding wings, a significant change, but the overall design was not affected)

Naval Squadron Designations

$\begin{array}{llll}\text { VB } & \text { Bomber squadron } & \text { VSB } & \text { Scout Bomber squadron } \\ \text { VF } & \text { Fighter squadron } & \text { VMF } & \text { Marine Fighter squadron } \\ \text { VP } & \text { Patrol squadron } & \text { VMSB } & \text { Marine Scout Bomber squadron } \\ \text { VT Torpedo squadron } & & \end{array}$

United States Army Air Force Designations:

$\begin{array}{lll}\text { A } & \text { Attack } & \text { usually twin-engined light bombers } \\ \text { C } & \text { Cargo } & \text { Utility } \\ \text { P } & \text { Pursuit } & \text { fighter } \\ \text { B } & \text { Bomber } & \text { applied to medium and heavy bombers }\end{array}$

Note: (USAAF aircraft were assigned a numberdesignator in series, i.e., $\mathrm{P}-39, \mathrm{P}-38, \mathrm{P} 40$, bombers were also numbered in the same manner, B-17, B-25, B-26, B-29. Modification variants used alphabetical designations, i.e., A, $B, C$. Therefore, the $\mathrm{P}-51 \mathrm{~A}$ was a pursuit fighter with a razorback design and a cockpit greenhouse. The $\mathrm{D}$ version had the razorback spine removed and a bubble canopy to cover the cockpit. 


\begin{tabular}{|c|c|}
\hline & \\
\hline $\mathrm{ACE}$ & Pilot with five or more kills \\
\hline AI & Airborne Intercept radar \\
\hline AN & Army-Navy \\
\hline Anti-Aircraft & Gun used in the defense against aircraft \\
\hline APS & Airborne Pulse Search \\
\hline BB & Battleship (14-18inch naval guns) \\
\hline Blip & Radar return, same as contact \\
\hline Bogey & Radar return of unidentified contact \\
\hline Bubble & $\begin{array}{l}\text { Aircraft canopy, like a bubble, giving the } \\
\text { pilot a clear, all-round view }\end{array}$ \\
\hline CA & Cruiser-heavy ( 8 inch naval guns) \\
\hline CAP & Combat Air Patrol-a defensive fighter screen \\
\hline Catapult & $\begin{array}{l}\text { Device used to launch float equipped aircraft } \\
\text { from a ship, i.e., Battleships, Cruisers }\end{array}$ \\
\hline Chaff & $\begin{array}{l}\text { Strips of aluminum foil designed to confuse } \\
\text { i.e. chause clutter, an enemy radar set. } \\
\text { see Window }\end{array}$ \\
\hline CINCLANT & Commander in Chief Atlantic \\
\hline CINCPAC & Commander in Chief Pacific \\
\hline CL & Cruiser-light (6inch naval guns) \\
\hline Coastwatcher & $\begin{array}{l}\text { Australian planter left on isiand to observe } \\
\text { \& report }\end{array}$ \\
\hline Combat Radius & $\begin{array}{l}\text { Distance an aircraft can fly, carry out } \\
\text { mission and return to base }\end{array}$ \\
\hline Contact & Radar return, usually identified, see Bogey \\
\hline CVA & Carrier-attack class \\
\hline CVI & Carrier-light \\
\hline CVE & Carrier-escort: \\
\hline Daihatsu & Japanese, motorized, barge \\
\hline $\mathrm{DD}$ & Destroyer \\
\hline $\mathrm{DE}$ & Destroyer-escort \\
\hline False Return & $\begin{array}{l}\text { Erroneous radar return showing something } \\
\text { which isn't there }\end{array}$ \\
\hline Flamed & $\begin{array}{l}\text { Japanese aircraft had a tendency to explode } \\
\text { into flame when hit by } .50 \text { caliber machine } \\
\text { gun fire }\end{array}$ \\
\hline GCI & Ground controlled Intercept, radar \\
\hline GER & Germany \\
\hline Ghost & False radar return \\
\hline Glitches & Electronic problems in radar gear \\
\hline Greenhouse & Aircraft cockpit with multiple panels \\
\hline Ground clutter & $\begin{array}{l}\text { Interference with radar return causing too } \\
\text { much paint }\end{array}$ \\
\hline HVAR & High Velocity Aerial Rocket \\
\hline Hybria & $\begin{array}{l}\text { Japanese battleship with partial flight } \\
\text { deck }\end{array}$ \\
\hline IFF & Identification, Friend or Foe, see \\
\hline
\end{tabular}


IJN

Interceptor

Luftwaffe

Nulis

Paint

Plot

PPI

PT

Pursuit

RAF

Razorback

Scope
Scramble
SeaBee
Shore Battery
Sighting
Snooper

TF

Transponder

USAAF

USMC

USN

Vector

watch

window
Imperial Japanese Navy

Fighter plane, early usage. See Pursuit German Air Force

Blank areas in radar return caused by glitches

Radar scope imagery, i.e., returns

Marking a bogey or contact position on a chart

Planned Position Indicator, radar scope

Patrol Torpedo

Fighter plane, early usage. See Interceptor

Royal Air Force

Aircraft design with the fuselage running from the cockpit canopy to the tail, i.e., a dorsal spine

Radar display, cathode ray tube

Rapid take-off or launch of aircraft

Naval construction worker

Naval gun established on land for defense

Radar detection of a bogey

Shadowing aircraft, observing and reporting movement of surface units

Task Force, generally included one or more carriers

Radar set enhancement capable of being interrogated by radar pulse. See IFF

United States Army Air Force

United States Marine Corps

United States Navy

A direction to a bogey

on duty, watching for an enemy ship or plane Strips of aluminum foil cut to the precise wave length of an enemy radar to cause clutter on the radar scope. See Chaff 


\title{
Introduction
}

\begin{abstract}
Wars, throughout history, have often resulted in the modification of the existing military technology or the introduction of a radically new military technology. In World War I several new technologies--the armored tank, the airplane and chemical gas warfare-were introduced but never exploited to the point where any of them actually influenced the outcome of the war. During the interim period between World War I and the outbreak of World War II gas warfare was outlawed while armored tank technology was improved as was tactical doctrine for its use as a weapon of war by the Germans. In the navies of Japan, Britain and America, the airplane was linked to the aircraft carrier, another innovative concept which originated during World War I. To the battleship admirals of these navies, the airplane was only an extension of the existing, big gun, naval philosophy.

When World War II erupted in 1939 radar was an entirely new concept in military technology. Because it could not be seen with the naked eye, or felt or heard, it required a forward-thinking commander to recognize its potential. Only a handful of military officers visualized
\end{abstract}


the tactical use of radar in combat. When the United States of America was abruptly drawn into World War II on 7 December 1941 the men who were already developing the new technology of the airplane would embrace the military potential of radar.

When enemy forces are engaged in combat, it is not always the strongest force which wins the battle. Various factors may provide the weaker side with an advantage over the stronger. For example, weather can aid and/or hamper both combatants. Knowing what your enemy is planing can be a decisive advantage in combat, if the element of surprise can be employed. A new weapon, superior to any possessed by the enemy is always advantageous, but only if the side which wields such a weapon is proficient in its use. If the holder of a superior weapon does not properly employ it, then the advantage is lost. In the early months of the Pacific war both the Japanese and the American navies possessed aircraft carriers and their complements of combat aircraft, but neither the Japanese or the Americans realized the full potential of the aircraft carrier because strategic and tactical planners on both sides were advocates of the big-gun battleship for surface combat.

The Japanese Navy was recognized by all of the major navies as the undisputed master in nocturnal, surface, warfare. This ability to engage in night, surface combat 
gave the Japanese an advantage over their opponents. The American Navy had been provided with new radar technology which could neutralize the Japanese advantage, for it allowed the user to see electronically at night. Unfortunately, the men who were given the responsibility to implement this weapon had not learned how to use it before being thrust into the crucible of combat. It would take the United states Navy, two long, bloody years to learn how to use radar properly. The required lessons in the use of radar would be taught through the expediency of "on-the-job" live combat training before the new technology could contribute effectively to the war effort. 
Chapter 1

Prelude to War

The new, electronic phenomenon of radio ranging and detection was developed in the physics laboratories of the Naval Research Laboratory which had been set up in 1923 to develop and experiment with new forms of technology. The technology was passive in nature, in that, it did not overtly destroy or kill. What the technology offered was a means of electronically sensing objects, over great distances, during the day, night and in some inclement weather conditions. The military reduced the descriptive terminology for the electronic phenomena of radio detection and ranging to a simple acronym "RADAR."

In non-technical terms, radar transmits a burst or pulse of electronic energy within the VHF (Very High Frequency) radio spectrum. The pulse is emitted outward in a specific direction at the speed of light. When the electronic pulse strikes an object, called a bogey or contact, a portion of the energy which is not absorbed by the bogey is reflected back to the source where it is detected by the antenna of the radar set. The electronics within the radar set converts this reflected energy into a 
visible anomaly, called a blip, which is displayed on a cathode-ray-tube screen.

America was not the only country experimenting with radar. In the 1930's, experiments were conducted by physicists in England, Germany, France and Japan. During the early thirties the British developed a rudimentary form of radar which was capable of being carried aloft by an airplane. ${ }^{1}$ By 1934 the British had refined their radar to where a bearing, the direction to the contact, and a range, the distance to the contact, could be determined. The following year, the French government placed a radar receiver aboard the passenger liner Normandie to detect icebergs. ${ }^{2}$ The development of radar accelerated rapidly, and by 1936 British radar could detect an airplane at a distance of seventeen miles.

The American Navy placed an experimental radar set aboard the destroyer Leary in April 1937, and the performance of the test was so successful that the Navy decided to install a prototype radar aboard a vessel in the Caribbean fleet exercises scheduled for January, February and March of 1939. During the fleet exercises, a prototype

${ }^{1}$ Richard C. Knott, Capt., USN., Black Cat Raiders of WW II (Annapolis: The Nautical \& Aviation Publishing Company of America, 1981), 61.

${ }^{2}$ David K. Allison, New Eye for the Navy: The origin of Radar at the Naval Research Laboratory, (Washington D.C.: Naval Research Laboratory, 1981), 93. 
radar, designated XAF, which had been developed by the Naval Research Laboratory was installed aboard the battleship New York. At the same time a civilian firm, the Radio Corporation of America, was allowed to install its privately developed radar, designated as the CXZ prototype, aboard the battleship Texas. ${ }^{3}$ Although these radars were quite rudimentary, they were able to detect ships at ten miles and aircraft at forty-eight miles. The cxz radar model performed unsatisfactorily during the test, but XAF radar developed by the Naval Research Laboratory electrified the Navy by detecting approaching destroyers during the night while they were still beyond torpedo range! 4 Admiral A.W. Johnson, Commander of the Atlantic Squadron, was so impressed that he recommended the Naval Research Laboratory radar be installed aboard all aircraft carriers as soon as possible. In his report to the Bureau of Engineering he expressed the following opinion:

Commander, Atlantic Squadron, considers that the equipment [XAF Radar] is one of the most important military developments since the advent of the radio itself. 5

Four heavy cruisers, Chicago, Chester, Pensacola, Northampton, the aircraft carrier Yorktown and the

\footnotetext{
3. Ibid., 105.

4Ibid., 109.

${ }^{5}$ Ibid., 110.
} 
battleship California had been fitted with civilian manufactured radar sets, designated CXAM, by May 1940. Following the initial CXAM installations, the battleships Texas, Pennsylvania, West Virginia, North Carolina and Washington received improved versions, CXAM-1 radars, as did the heavy cruiser Augusta, the light cruiser Cincinnati and the carriers, Lexington, Saratoga, Ranger and Enterprise. Two additional CXAM-1 sets were installed aboard the larger seaplane tenders, Curtiss and Albermarle. ${ }^{6}$

In Japan, the phenomenon of radar was being studied in the physics laboratory, but the militarist leadership of the island nation saw the electronic technology as being "unworthy of the Japanese fighting spirit," and funding for the development of radar was severely restricted. ${ }^{7}$ This bushido mind-set of the Japanese military leaders was reinforced by their easy victories in the china Incident and it effectively blinded them to the potentials of radar.

The British, actively developing their own version, initially established an early warning radar to track aircraft as early as 1937. However, the problem with radar, for both the British and the Americans, was size. The initial radar sets took up a prodigious amount of space,

\footnotetext{
6Ibid., 111.

7 Knott, Black Cat Raiders, 61.
} 
requiring a room measuring twenty by thirty feet just to house the electronic gear which often weighed up to ten tons. Antennas also posed a problem in that they, too, were bulky and added to the overall weight of the system. It was no wonder that the initial installations were aboard the largest ships of the navy. ${ }^{8}$ The British managed a major breakthrough in 1937 when they developed a light-weight radar set which was capable of being carried aloft by an airplane. The new air-to-surface radars were installed aboard the British Short Sunderland flying boats by 1940 to enhance the effectiveness of their long range patrols over the Atlantic convoy routes as they searched for German surface raiders and the infamous U-boats that were devastating the supply convoys. ${ }^{9}$ The secret to the British breakthrough in radar technology was the development of a "multicavity magnetron" which boosted the radar signals to higher, more effective levels without having to increase the power output or size of the radar set. 10

When America unofficially entered the war against Germany by overtly escorting the Britisin and Canadian convoys with warships of the United States Navy, the British

\footnotetext{
8 Allison, New Eye for the Navy, 146.

$9^{9}$ Knott, Black Cat Raiders, 61.

${ }^{10}$ Allison, New Eye for the Navy, 148.
} 
responded by lending enough air-to-surface radar sets to equip an American patrol squadron, VP-55, flying the PBM Mariner flying boat out of newly acquired Icelandic bases. 11 Soon, America and Britain were freely exchanging their radar technology. The British contribution to the electronic technological exchange was the multicavity magnetron, which allowed smaller radar units to be developed for installation aboard the destroyers and smaller vessels in the American fleet.

Germany had not lagged far behind the British in developing airborne radar. The long range Focke wulf Fw200c, Condor, was equipped with the a German version of air-to-surface radar. These large, land-based patrol bombers sortied from their bases in occupied Norway to search out the convoys enroute to the Russian port of Murmansk. The primary mission of the Condor was as an aerial snooper to find and maintain contact with an Allied convoy until one or more German U-boat Wolf Packs could be brought into the kill zone. The system was far more effective than having the condor make a solo torpedo or bombing attack against armed cargo vessels which could mount

\footnotetext{
${ }^{11}$ Richard c. Knott, Capt., USN., The American Flying Boat: An 11lustrated History (Annapolis: Naval 'Institute Press, 1979), 146.
} 
a formidable defense against aerial attack. ${ }^{12}$

Radar, when initially deployed to the United states Navy in late 1941, took up what naval commanders saw as excessive space. Also, the early radar sets were prone to electronic malfunctions, ghosts, nulls and false echo returns. 13 The radars which were installed aboard larger vessels, carriers and battleships, could detect aircraft flying at ten thousand feet out to an distance of approximately 130 statute miles. However, the radars installed aboard the destroyers had a limited angle at which they could scan above the horizon; therefore, their radar effectiveness was restricted in detecting aircraft to a range of approximately thirty-five miles. Battleships could be detected at eleven miles and destroyers at three miles. ${ }^{14}$ When the new radar technology was tested under live, combat conditions, the results did not meet the expectations of the commanders of the ships involved. Subsequently, these naval commanders reverted to the tried and proven methods of traditional surface combat for which they had been trained.

\footnotetext{
12John Hamilton, et al., eds., War at Sea, 1939-1945 (New York: Blandford Press, 1986), 41.

${ }^{13}$ Chuck Hansen, USS San Francisco (CA-38): A Technical History (Missoula, MT: Privately Printed, 1978), 50.

${ }^{14}$ Ibid., 50.
} 
The Japanese involvement in World War II was the direct result of their dream to establish a "Greater East Asia coprosperity Sphere" in the Pacific. Although the Japanese preferred to establish their Asian empire through peaceful negotiations, they recognized that America would be one of the principal obstacles that could prevent the dream from becoming a reality. The Japanese realized that if a war were to be fought with America, it would be the primary responsibility of the Imperial Japanese Navy to neutralize the American Pacific Fleet based at Pearl Harbor, Hawaii. The plan to deal with the American Pacific Fleet by a preemptive aerial strike upon Pearl Harbor at 0800 hours, 8 December 1941, Tokyo time, had been formulated as early as 22 October 1941.15 Air units of the Japanese Navy were already training for the attack, secretly practicing on mock targets with aerial torpedoes modified to run in the shallow waters of Pearl Harbor.

The actual decision to go to war with America was made during the Liaison Conference of 5 November 1941, when Admiral Osami Nagano, the Japanese Naval Chief of Staff, was asked to present a comparison of the naval strengths of Japan and America to the policy conference members and to

\footnotetext{
${ }^{15}$ Matome Ugaki, Fading Victory: The Diary of Admiral Matome Ugaki 1941-1945, edited by Donald M. Goldstein, Katherine v. Dillon, trans. Matsataka Chihaya (Pittsburgh: University of Pittsburgh Press, 1991), 9.
} 
give his opinion on the outcome of a war with the United States. Admiral Nagano, although opposed to a war with America, stated:

on the surface the Americans hold an advantage of 10 to 7.5. However, $40 \%$ of the American fleet is in the Atlantic which gives the Japanese an almost equal parity in the Pacific. ${ }^{16}$

Nagano knew that Japanese warships were considerably faster and carried more guns than warships of the American Navy. Two battleships, Yamato and Musashi, had been constructed in total secrecy, each mounting eighteen-inch naval guns to make them the most powerful battleships in the world. Nagano was confident that America would not have sufficient strength, especially if the United States Pacific Fleet were neutralized, to win a decisive victory in the Pacific. ${ }^{17}$ The Japanese admiral discounted radar as a potential advantage for the Americans.

Prior to Pearl Harbor, American code breakers had cracked the Japanese "Purple" diplomatic code. When Baron Hiroshi Oshima, the Japanese ambassador to Nazi Germany, began to send voluminous dispatches over the international telephone cable, the American code breakers became privy to the Japanese obsession to establish a "Greater East Asia Co-

${ }^{16}$ Nobutake Ike, ed., Japan's Decision for War: Records of the 1941 Policy Conferences (Stanford: Stanford University Press, 1967), 233.

${ }^{17}$ Ibid. , 233. 
prosperity Sphere" and Japan's strategic plans to go to war with America. ${ }^{18}$ The diplomatic intercepts were code named "Magic" by the American code breakers, but Magic intercepts did not provide the tactical details of the Japanese naval strategy, the precise point of the attack, the time and the order of battle. This information was communicated through Japanese naval codes, and although the American code breakers were desperately attempting to crack these codes, according to official accounts, they were less than fully successful.

An arrogant and prejudicial mind-set on the part of various American leaders, both political and military, with regard to the Japanese as a potential enemy, undermined America's preparedness. On the eve of war, 6 December 1941, Senator Owen Brewster (R-Maine) stated in a speech to the Welfare Club at the Naval Air Station in San Juan, Puerto Rico: "the United States Navy can defeat the Japanese Navy at any place and at any time."19 Japan could bluster and threaten, but the tiny island nation would never have the audacity to attack the United states of America! This irrational attitude on the part of many members in Congress

\footnotetext{
${ }^{18}$ Ronald Lewin, The American Magic: Codes, Ciphers and the Defeat of Japan (New York: Penguin Books, 1983), 233.

${ }^{19}$ Gordon W. Prange, Donald M. Goldstein and Katherine V. Dillon, December 7, 1941: The Day the Japanese Attacked Pear 1 Harbor (New York:
} 
and numerous military commanders created a trickle down attitude which reached the lowest levels of the United states defensive structure. The defensive measures taken against the Japanese threat at Pearl Harbor were halfhearted alerts and the concentration of aircraft onto the center of the airfields to protect against the hypothetical threat of sabotage. Meanwhile, the Pacific battleships were placed in two rows around Ford Island while the destroyers were nested beside their tenders, as were the submarines and other vessels. This orderly arrangement of America's naval strength at Pearl Harbor, with the fore-knowledge that the Japanese had formulated aggressive plans for conquest in the Pacific, would provide fuel for a controversy that still rages. Was the American fleet deliberately allowed to be attacked as a means of bringing America into the war with Germany? 


\section{Chapter 2 \\ 7 December 1941}

On the morning of 7 December 1941, the only naval ships in Pearl Harbor which were equipped with radar were the battleships Pennsylvania, California and West Virginia along with the sea-plane tender curtiss. The radar of these ships could not be operated within the harbor because the surrounding mountains caused ground clutter, making the sets totally ineffective. Since it was a sunday morning, the military establishment was still operating in an off-hours, weekend mode and they were totally unprepared for what was about to happen.

Early warning radar had just been installed on four mountain peaks--Kaaawa, Kawailoa, Koko Head and opana-on the Hawaiian Island of Oahu. As a back up, a fifth set was placed at Fort Shafter where the radar plot center was also located. 20 These early warning radar sets were operated by enlisted technicians attempting to hone their newly learned skills. At the same time, inexperienced officers were placed in charge of the radar plot center at Fort

$$
{ }^{20} \text { Ibid. . } 94
$$


Shafter, and only a few procedures had been actually worked out for scrambling interceptor fighters to investigate any unidentified bogey.

At 0651, Koko Head radar reported four contacts south of Oahu. However, the enlisted operators were not able to ascertain if the bogeys were friend or foe because the IFF (identification, friend or foe transponder) had not been invented. It was simply assumed that the only aircraft which would be anywhere within the vicinity of oahu would be the Navy's PBY Catalina flying boats operating from the naval air stations at Kaneohe and Ford Island. With hindsight, it is now suspected that these bogeys were four Mavis flying boats, operating from a Japanese submarine acting as a seaplane tender located near French Frigate Shoals in the Central Pacific. ${ }^{21}$ The Japanese snoopers were probably withdrawing after an investigation of the disposition of ships in Pearl Harbor prior to the actual attack.

At 0652 , Kawailoa reported four sightings, this time north of Oahu. Again, the radar plot officer at Fort Shafter, who had also detected the bogeys on his back-up radar, declared them as friendly.

Kaaawa radar reported five bogeys, also north of Oahu, ${ }^{21}$ Ibid. , 81 . 
at 0654 hours. Again, these sightings were dismissed as being friendly, using the original assumption that they were Catalinas on their routine morning patrols.

Opana radar, which had been scheduled to shut down at 0700 hours, was left running because the inexperienced operators were told that the truck scheduled to take them off the mountain would be delayed. Therefore, the young operators decided to gain additional experience by working the electronics until the truck arrived. The radar procedures in effect at the time required that any contact of a bogey be relayed by telephone to the Fort shafter radar plot officer. The officer on duty would decide if interceptors should be scrambled to make an investigative intercept.

At 0700 , opana radar reported a very large blip on their screen. At Fort shafter, the officer standing the radar plot watch was a fighter pilot who did not understand the radar procedures in use. He assumed that one of two factors existed: Either the rookie operators at opana had a malfunctioning set or the large blip represented a formation of American B-17E Flying Fortress bombers which was scheduled to arrive between 0730 and 0745 hours that morning. It is also quite probable that the inexperienced radar plot officer did not want to endure the embarrassment of having to explain why he scrambled a couple of 
interceptors to investigate what might have turned out to be a flock of birds, especially on sunday morning. Therefore, the radar plot officer took it upon himself to make a command decision. No fighters would be scrambled! 22 Opana radar continued to track the bogeys until it was shut down when the chow truck arrived at 0739 hours to transport the radar operators off the mountain.

Approaching Oahu at 0700 hours on Sunday morning, 7 December 1942 were 216 Japanese naval strike planes flying from six Japanese attack carriers. The strike group of the first attack wave contained 131 Val dive bombers, forty Kate torpedo bombers and forty-five zero fighters. At 0753 hours, the first wave of the infamous Japanese attack on Pearl Harbor commenced without any defensive fighters to oppose them. Within minutes, the battleships Arizona, oklahoma, Nevada, California and West Virginia were sunk. Utah, an old battleship which served as a target ship was also sunk because the Japanese had mistaken her for an aircraft carrier. The battleship Pennsylvania, which was in drydock at the time, was severely damaged as were numerous other vessels. The second wave struck at 0900 hours with a total of 186 aircraft; seventy-eight val dive bombers, fifty-four Kate torpedo bombers armed with bombs and fifty-

$$
{ }^{22} \text { Ibid., } 94 .
$$


four zero fighters. These aircraft concentrated on the airbases and other military installations in and around Pearl Harbor. A few American fighters had managed to become airborne, but when the last Japanese attacker had departed, the tally was eighteen ships sunk and/or damaged, 165 aircraft destroyed, 2,403 people killed and 1,178 wounded. The Japanese lost twenty-nine aircraft and five midget submarines. 23 Radar, which might have changed the course of history, did not fail because of equipment malfunctions. It failed because the men charged with the operation of the electronics were inept due to their inexperience with radar and an arrogant attitude that the Japanese would never dare to attack Pearl Harbor.

When Vice Admiral Chuichi Nagumo, the commander responsible for carrying out the raid, learned there were no American carriers in the harbor, he canceled a third air strike. Where were the American carriers? Enterprise was returning from delivering a dozen $\mathrm{F} 4 \mathrm{~F}-3$ wildcat fighters to VMF-211, the Marine fighter squadron based on Wake Island. Enterprise, with its escort of heavy cruisers and destroyers, was only 130 miles from oahu. ${ }^{24}$ Although it

\footnotetext{
${ }^{23}$ Stan Cohen, East Wind Rain: A Pictorial History of the Pearl Harbor Attack (Missoula, MT: Pictorial Histories Publishing Company,

${ }^{24} \mathrm{John}$ B. Lundstrom, The First Team: Pacific Naval Air Combat from Pearl to Midway (Annapolis: Naval Institute Press, 1984), 17-26.
} 
was entirely possible that the Enterprise could have picked up the Japanese aircraft on its radar as they returned to their carriers, there is no evidence that it did. Lexington was just reaching its launch point to fly off a dozen, SB2U Vindicator dive bombers to augment VMSB-231, the Marine dive bombing squadron on Midway Island, when it received word of the Japanese attack on Pearl Harbor. The launch was canceled and Lexington returned to Pearl the following day. ${ }^{25}$ Saratoga, the third American carrier in the Pacific, was enroute to San Diego, California from Bremerton, Washington. Saratoga was scheduled to pick up a complement of naval F2A-1 Buffalo fighters along with other carrier aircraft scheduled for delivery to the fighter and bomber pool at Pearl. Yorktown and Hornet were both on loan to CINCLANT, the Atlantic Command, where they operated out of Norfolk, Virginia. ${ }^{26}$ Yorktown would be quickly rushed to the Pacific, followed by Hornet, via the Panama Canal. The aircraft carriers would introduce radar to combat in the Pacific.

The Japanese launched their offensive against the Philippines on 8 December 1941, Manila time, which was the same day as the attack upon Pearl Harbor. The attack opened

\footnotetext{
${ }^{25}$ Ibid., 26-32.

${ }^{26}$ Ibid. , 32-37.
} 
with an air raid conducted by land-based Nell bombers of the Japanese Navy. These bombers had flown from their bases on Formosa to strike military installations in and around Manila. However, the principal target of the attack was Clark Air Force base where, as at Pearl, the aircraft had been concentrated on the center of the airfield as a precaution against sabotage. The military command in the Philippines had received word that Pearl Harbor had been attacked several hours earlier, and the Japanese had bombed installations on Luzon during the morning. Yet, in spite of the irrefutable evidence that the Japanese would attack in force, complacency by the military commanders resulted in their doing nothing to augment the meager defensive measures then in effect. 27 Even if early warning radar had been available, it is probable that the inexperienced operators and radar plot officers would have been as inept as those at Pearl. Therefore, when the attack commenced, no American fighters were aloft to intercept the incoming Japanese bombers; in one bold stroke, the Japanese effectively neutralized the aerial defenses of the Philippines by destroying seventeen out of thirty-five B-17E bombers, and

\footnotetext{
27 Tameichi Hara, Capt., IJN, Japanese Destroyer Captain: Pear1 Harbor, Guadalcanal, Midway-the Great Naval Battles of the Pacific as Seen Through Japanese Eyes, with the collaboration of Fred Saito and Roger Pineau (New York: Ballantine Books, 1961), 56.
} 
forty out of ninety-three P-40A warhawk fighters. ${ }^{28}$

Two days later, on 10 December 1941, off the Kuantan Peninsula, the pride of the British fleet, the battleship Prince of Wales, and her consort, the battlecruiser Repulse, were enroute to interdict the Japanese landings on the eastern coast of the Malayan Peninsula when they were discovered by a Mavis flying boat. The British ships, which comprised Force Z, were shadowed by the snooper patrol bomber while it radioed periodic position reports to its base in Indo-china. Although the Prince of Wales and Repulse were equipped with radar, it was of no consequence, for the two warships were beyond the range of friendly fighters which were based at singapore. The British commander of Force $\mathrm{z}$, Rear Admiral Thomas Phillips, had sailed with the arrogant attitude that his two battleships could deal with anything the Japanese could throw against him, and he was confident that his anti-aircraft defenses were more than adequate to protect the two warships from any air attack. 29 The Japanese commander of the 22 nd Air Flotilla, Rear Admiral Sadachi Matsunaga, ordered a squadron of Bettys, the newest medium attack bomber, to destroy the two warships with bombs and torpedoes. Radar is a passive

\footnotetext{
${ }^{28}$ Ibid. , 56.

${ }^{29}$ Richard Hough, The Longest Battle: The War at Sea 1934-45 (New York: William Morrow and Company, Inc., 1986), 147.
} 
weapon. It can provide a warning of an impending attack, but it can take no overt action to thwart it. Without air cover to protect them, the British warships were totally vulnerable to the Japanese air attack. Within minutes, both vessels were sunk.

In the early stages of the war, 1941 to 1943, radar was a primitive technology. Early radar sets used the "A" scope, which did not provide a visual, situational display as do the planned position indicator (PPI) scopes of today. The early radars simply presented the radar operator with a tiny blip to indicate a contact. The range and bearing to a contact was provided by the set, but the number of elements involved could only be determined by an educated "guesstimate" based upon the size of the blip on the scope. Altitude for a contact was also established by the process of educated "guesstimation" while the speed and course of a bogey could only be obtained after plotting a number of sightings for the same contact onto a 360-degree polar chart and computing the velocity by using a time-distance mathematical formula. A line drawn through the multiple plot points caused by the same contact would also reveal the course of the bogey. Nulls, ghosts and inherent quirks within the electronics made matters more difficult. 30

\footnotetext{
${ }^{30}$ Lundstrom, First Team, 110-112.
} 
The problem of recognizing a friendly contact from a hostile contact was a major difficulty for the radar plot officers. If no friendly aircraft were in the air, an incoming bogey could be assumed to be hostile. If a combat air patrol (CAP) was in the air and the position and altitude of the CAP were known, then an approaching bogey could again be assumed to be hostile. However, if there were numerous aircraft in the air which were both friendly and hostile and engaged in various combat roles, the radar plot and fighter director officers aboard the ships could be easily overwhelmed. The development of the IFF transponder radio which could be interrogated by a radar signal to determine if the contact were friend or foe, was being developed in the laboratories, but during the first few months of the Pacific War the sets were unavailable for combat use.

The importance of the IFF transponder was demonstrated during the Marshall Islands raid of 1 February 1942. A decision was made to "tweak" the nose of the Japanese Navy by striking at the Japanese mandated islands, the Marshalls and Gilberts, in the Central Pacific. The carrier Yorktown sailed with Task Force seventeen (TF-17), while Enterprise sailed with Task Force eight $(T F-8)$. The plan was to allow the carriers to make simultaneous raids upon the islands of Jaliut, Makin, Mili, Roi and Wotje while the task force 
cruisers conducted bombardment exercises against shore installations. The raids would become a dress rehearsal for pilots and fighter director officers aboard the carriers. Procedures for controlling the fighters had not been established and these procedures would have to be developed through a process of trial and error under combat conditions. One of the problems which would plague the fighter director officers was that each squadron, based aboard their respective carriers, used a different radio frequency and none of the aircraft carried an IFF transponder. 31 Maintaining a running fix on each of the radar plots became a nightmare for the carrier fighter director officers, especially when the cruisers began to send up their soc-1 seagull, float observation biplanes as spotters for directing naval gunfire onto the shore installation targets. Aboard each of the carriers the fighter director officers could only guess at which of the multiple contacts registering on the cluttered radar screen were friend or foe.

The Marshall Island raids were carried out with the finesse of a high school drama club's opening night. Attacking aircraft missed their cues and circled over the Japanese airfields until the Japanese were alerted to their

\footnotetext{
${ }^{31}$ Ibid. , 80-101.
} 
presence. The attacks were then made in uncoordinated, haphazard runs on the airfields while the Japanese scrambled their nimble little open cockpit claude fighters with fixed landing gear in an attempt to shoot the Americans down. The 1 February raid was a total military fiasco resulting in little damage to the enemy. But as a dress rehearsal to reveal the problems of radar-controlled combat the raid was a major success.

Prior to the installation of radar, a carrier would establish a combat air patrol of four to six fighters to circle over the task force during daylight hours in order to detect and intercept any aircraft that approached the ships. Approaching aircraft had to be spotted visually. A good pilot with sharp eyesight might pick up an aircraft at thirty miles in clear weather. With cloud cover it could be a very difficult task. To make a positive identification, a section of two, sometimes four, aircraft would be dispatched from the CAP to fly towards the approaching contact until a positive identification could be made. If the contact was identified as hostile, the investigative section would initiate an attack while transmitting a radio warning to the carrier. However, four to six fighters were not enough to engage a squadron of enemy bombers effectively, especially if they were accompanied by a fighter escort. Once the carrier had received a warning, it had to turn into the wind 
to launch its fighters. Fighters were flown off the carrier's deck one at a time, a procedure which could cost valuable time, and time was the critical factor. If the approaching enemy could penetrate the aerial defensive screen, the task force would be at risk to a concentrated aerial attack.

With the installation of the CXAM-1 radar aboard the carriers of the American fleet, the task force was able to detect approaching aircraft at distances beyond the range of even the most visually adept pilots. The problem of identification remained, but radar allowed the fighter director officer to provide fighters sent to investigate a bogey with a direction to fly, augmented by corrections as the distance, altitude and position of the approaching contact became refined.

The most significant contribution by radar during the early months of the war was its ability to provide the carrier with the necessary cushion of time, allowing it to launch enough fighters to engage the enemy in a running duel as it approached the task force. The role of the fighter director officer was critical. He made the decision to vector the CAP by section or as a group for intercepting any unidentified aerial contact. His decision could win or lose the battle!

The importance of radar and the fighter director 
officers' role in combat became clear on 20 February 1942 when TF-11, with Lexington, ventured into Japanesecontrolled waters off Bougainville. Vice Admiral Wilson Brown, in command of the American task force, had intended to mount a carrier air strike upon the Japanese harbor at Rabaul, New Britain Island, but the American task force was discovered by a Mavis flying boat while still 450 miles from the intended target. Lexington's fighter director officer, Lieutenant Frank F.G. "Red" Gill, picked up the enemy snooper and vectored a section of his CAP to investigate. Unfortunately, the large Japanese flying boat was able to radio a contact report to its base at Rabaul before it was shot down. 32 When the Japanese received the report of an American carrier operating off Bougainville, a strike force of eighteen Betty bombers was dispatched to destroy the impudent Yankees. The Japanese bombers were required to fly without fighter escort because the reported carrier was beyond the distance the zero fighters could fly, engage in combat and safely return. The Japanese Navy had yet to encounter any serious opposition from the American Navy, and the Japanese had developed a disdain for their enemy which made them confident that a fighter escort would not be required.

\footnotetext{
${ }^{32}$ Ibid. , 115.
} 
Radar aboard the Lexington picked up the enemy bombers seventy-five miles from the task force at an estimated altitude of 11,500 feet. "Red" Gill, as the fighter director officer, vectored his entire CAP of six wildcat fighters to intercept while the Lexington turned into the wind to launch additional fighters. The CAP made the intercept twenty-six miles from the task force. As the enemy bombers approached the task force, additional fighters from Lexington relieved the CAP fighters which had exhausted their ammunition and fuel. In the running battle all of the Betty bombers were shot down, the last bomber being "flamed" just as it reached the periphery of the task force. Not only had the importance of the fighter director officer been realized, but for the first time radar had proven its worth in a carrier battle. ${ }^{33}$ If radar had not been available to provide the Americans with the time needed to launch the additional fighters, the battle might have resulted in the destruction of the Lexington.

At this time the Dutch East Indies were in a near state of collapse. The Japanese schedule of conquest was rapidly accelerating, and the American Navy appeared to be an impotent adversary, unable to staunch the tide of Japanese aggression. America needed to do something, anything, to

\footnotetext{
${ }^{33}$ Ibid., 130.
} 
make the Japanese realize that the United States Navy was not defeated. A plan was conceived to attack the Japanese homeland using the B-25 Mitchell medium bomber of the United States Army Air Force flying from an aircraft carrier. TF16, with Enterprise, would provide aircover while the carrier Hornet, which had secretly slipped into the Pacific, would carry the Army bombers. Hornet proceeded to San Francisco where sixteen of the Mitchells were loaded from the wharf at the Alameda Naval Air Station onto the carrier's flight deck. 34 The "Army" carrier then sailed to rendezvous with Enterprise in mid-ocean. While 650 miles from Tokyo, the principal target city, the radar installed aboard the heavy cruiser Northampton picked up a large Japanese fishing trawler which was also acting as a early warning picket. The sighting was flashed throughout the task force, and the picket was sunk by gunfire from the Northampton, but not before the trawler had managed to send a contact report to Tokyo.

The speed of the American carriers was a known factor. The number of aircraft carried by American carriers was also known, and the Japanese knew that American carrier strike planes only had an effective combat radius of approximately 190 miles. Therefore, the Japanese military leaders assumed

\footnotetext{
${ }^{34}$ Ibid. , 181.
} 
there would be plenty of time, at least six hours, to prepare a defense to deal with a carrier-based air strike. ${ }^{35}$ The Imperial Japanese Navy was alerted to begin preparations to engage the impudent Yankees in a "classic" surface battle.

Japan did not have early warning radar. Therefore, when the sixteen Mitchells, led by Colonel Jimmy Doolittle, suddenly dropped their bombs upon the helpless civilian populace of Tokyo on 18 April 1942, there were no fighters in the air to oppose them. Japan's military leaders were shocked. They could not believe the Americans actually had been able to attack the Japanese Home Islands! Granted, the attack accomplished little in the way of military damage, but two priorities were immediately obvious. Because the Japanese couldn't believe the bombers had come from a carrier, it was recognized that Japan needed to establish a presence in the Aleutian Islands in order to prevent any more raids by land based-bombers, and (2) the United states Pacific Fleet had to be dealt with. The solution to both problems resulted in the formulation of a grandiose plan to lure the American Navy into a trap. Midway Island would be the bait. ${ }^{36}$

\footnotetext{
${ }^{35}$ Ibid. , 187.

${ }^{36}$ Ugaki, Fading Victory, 113.
} 
Chapter 3

Coral Sea

The Japanese recognized that an outer defensive perimeter had to be established to protect their growing "sphere of influence" in the South Pacific. Therefore, bases would have to be established in the South Pacific archipelagoes of the Philippines, the Solomons and on New Guinea. Port Moresby, an Australian bastion on the southern side of New Guinea, was to be the southern anchor for this chain of Japanese bases. The Japanese had already established their presence on the northern side of New Guinea, at Lae and at Salamaua, but the Owen Stanley mountains formed an almost impenetrable barrier which would have to be crossed in order to attack Port Moresby by land. A far more expedient method was to send an invasion force through the coral sea and around the eastern tip of New Guinea to attack the Australian bastion by sea. Admiral Chester Nimitz, Commander in Chief Pacific Operations, was aware from intelligence reports of Japanese intentions to capture Port Moresby. Additional intelligence sources, radio intercepts, photographic reconnaissance and pilot reports had indicated the Japanese were building up a 
large invasion fleet, including a number of cargo/transport vessels. It was obvious to Admiral Nimitz that the Japanese were about to set their invasion plan into motion. Nimitz had two carrier task groups operating in the South Pacific, TF-17 with Yorktown and TF-11 with Lexington. The carriers Enterprise and Hornet were returning to Pearl Harbor from the Tokyo raid, and the ideal solution would have been to combine all four carriers into one powerful task force, but Nimitz couldn't wait for Enterprise and Hornet to arrive. He had to act with the assets available to him. Nimitz ordered Yorktown and Lexington to rendezvous in the coral Sea where they would operate as $T F-17$ to attack the Japanese invasion force as it attempted to sail around the eastern cape of New Guinea. Nimitz knew that $\mathrm{TF}-17$ would not have the advantage of superior strength, but it was the strongest Allied force in the South Pacific at the time. 37

If the carrier strikes in the Marshall Islands had been dress rehearsals, then the coral sea would be "opening Night." Where the Marshall raids had involved two carriers operating independently, the coral sea operation would involve two carriers operating for the first time as a coordinated team. The fighter director officers aboard each carrier had worked out a number of solutions to the problems

\footnotetext{
37 Edwin P. Hoyt, Blue Skies and Blood: The Battle of the Coral sea (New York: Paul S. Eriksson, Inc., 1975), 16.
} 
which had previously plagued them. One carrier would stand radar watch while the second carrier used its radar as a back up in the event the primary radar control should be lost. The radar watch carrier would provide all of the fighters needed for the task force CAP, while the second carrier's fighters would escort the strike aircraft. The fighter director officer of the radar watch carrier would have total responsibility for control of the CAP in defense of the combined task force. Thirty-nine fighters, twentyone from Lexington and eighteen from yorktown, comprised the total fighter strength. The meager number of fighters from the two carriers severely limited the number of aircraft available to provide both $\mathrm{CAP}$ and escorts for the carrier strike bombers. ${ }^{38}$ However, several of the fighters carried the new IFF transponders. The fighter director officers decided to organize their sections with an IFFquipped fighter accompanied by two or three non-IFF-quipped fighters. This would make the problem of sorting out friend from foe easier, at least until the fighters engaged in an aerial melee. ${ }^{39}$ The problem of different radio frequencies remained an unresolved problem. On 2 May, radar aboard Yorktown picked up a Mavis

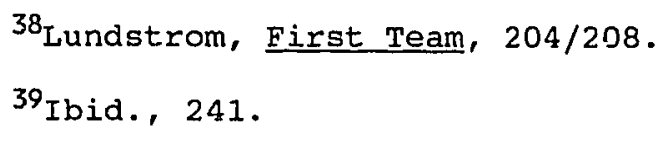


flying boat which was shadowing the task force. A two plane section from the CAP was dispatched to shoot it down. The destruction of these large, four-engined flying boats was becoming routine for the fighter pilots who flew the combat air patrols. With radar to guide the American fighters, an enemy snooper could no longer hide safely within a cloud, for when it emerged, the deadly little wildcat fighters would be waiting to pounce upon it.

Rear Admiral Frank Fletcher received intelligence from Pearl that the Japanese were establishing a seaplane base on the island of Tulagi in the Solomon Island chain. He ordered an air strike to break up their activity. On 4 May 1942, aircraft from Yorktown struck without warning. The Tulagi attack was a total surprise to the Japanese. Because the Japanese did not have an early warning radar, the Americans were able to approach unseen. The raid, which resulted in the sinking of several mine sweepers was a moderate success for the Americans. For the Japanese, it was a revelation because they realized they had made a mistake in dismissing the electronic phenomenon of radar as "unworthy."

on 6 May, the American task force refueled from the oiler Neosho, and sent it off to safer waters with the destroyer sims as an escort. Facing Yorktown and Lexington were two powerful Japanese attack carriers, Shokaku and 
Zuikaku. A third light carrier, Shoho, sailed with the transports to provide aircover, but its airgroup was insufficient for anything other than a meager defense over the transports.

Radar is line-of-sight restricted. It cannot see over the horizon. Therefore, to locate an enemy surface force over the horizon a number of search planes would be sent out in a fan shaped pattern. Both antagonists used this method of search, and each experienced the same inherent problems of human error. An error in judgment or identification could be crucial, for the advantage would go to the force who sighted the enemy first. On 7 May at 0722 hours a Japanese Kate sighted the Neosho and the sims. The two American ships were reported as an aircraft carrier and a cruiser and this erroneous report caused Vice Admiral Takeo Takagi to order an immediate preemptive strike to the coordinates of the phantom carrier.40 A few minutes later, an American Flying Fortress sent a contact message which reported a Japanese aircraft carrier sailing in consort with ten transports. Yorktown immediately launched its own strike groups. The only role radar would play in the engagements would be as an early warning system for the American carriers.

\footnotetext{
${ }^{40}$ Hoyt, Blue skies and Blood, 36 .
} 
While the Japanese were attacking the Neosho, the American pilots discovered the light carrier shoho. The small Japanese carrier was sunk and its small contingent of fighters destroyed, while the Japanese sank the destroyer Sims and reduced the oiler Neosho to a burning hulk. Radar aboard Lexington picked up the Japanese aircraft as they returned to their carriers. The Americans thought the bogey represented a strike group which was probably looking for $\mathrm{TF}-17$ and a decision was made to refrain from engaging the enemy. At 1750 hours, the radar aboard Lexington picked up another, very large bogey. This time the two American carriers launched thirty wildcat fighters to augment the CAP while additional SBD-3 Dauntless dive bombers were launched to form an anti-torpedo-plane defense around the carriers at a lower altitude. The radar had picked up the approaching bogeys in time to allow the American fighters to climb to a position from which they could attack the enemy without warning from above. One additional bonus was presented to the American pilots. The enemy bombers were not being escorted by any fighter aircraft. When the Americans attacked, the Japanese were obliged to jettison their bombs and torpedoes in an attempt to escape. Not all of them were lucky. Five out of nine Kates were destroyed, while three out of six Vals were shot down. The radar contact plots on the polar chart had also 
revealed the approximate location of the Japanese carriers. However, with nightfall only minutes away, Admiral Fletcher decided to postpone the attack until dawn on the 8 th of May. 41

As darkness fell, Yorktown and Lexington began to recover their aircraft. In the dusk, several unidentified aircraft approached the carriers and then initiated an unauthorized wave off. The fighter director officers aboard the American carriers suspected these unidentified aircraft were Japanese, but as only a few of the American fighters were equipped with the IFF transponders, it was impossible to identify them as friend or foe. The problem facing the fighter director officers was that alerting the defensive gunners of the task force that there were enemy aircraft in the landing pattern could easily initiate a disaster. The fighter director officers remained silent. The decision was made, inadvertently, by an American fighter pilot who, upon seeing an aircraft with elliptical wings emblazoned with a large, red, rising sun emblem, promptly shot it down. His action alerted the task force anti-aircraft gunners that Japanese aircraft had intruded into American airspace. The entire task force erupted in a display of defensive antiaircraft fire which resulted in the shooting down of more

\footnotetext{
${ }^{41}$ Lundstrom, First Team, 266.
} 
American planes than Japanese. 42

Knowledge of where the enemy is located, especially during a prolonged battle, can be a decisive advantage. During the mini-battle with the errant Japanese aircraft in the American landing pattern, the radar from both American carriers detected enemy aircraft circling at a distance of approximately thirty-five miles. It was suspected that these aircraft were attempting to land upon Japanese carriers operating just over the horizon. Again, Admiral Fletcher prudently decided to refrain from attempting a night surface engagement with the Japanese. 43

At first light, 0600 hours on 8 May 1942, the opposing forces launched scout planes. The Americans established a CAP of six wildcat fighters over the task force at ten thousand feet and six Dauntless Dive bombers forming an anti-torpedo defensive ring below five thousand feet. At 0807 hours, radar aboard Lexington picked up a Japanese bogey. The American task force had been located by the enemy. At 0820 hours, one of the Dauntless scouts reported two Japanese carriers. Both antagonists launched strike aircraft at approximately the same time. While the American strike groups were attacking the Japanese carriers, radar

\footnotetext{
42 Ibid., 270.

${ }^{43}$ Ibid. , 277.
} 
aboard Lexington picked up the incoming Japanese strike group sixty-eight miles from the task force. The alert fighters were launched to augment the CAP. Unlike the previous encounters with Japanese bombers, this time the enemy strike group was escorted by zero fighters. When the American fighters attacked the Japanese bombers, the Zeros counter-attacked, and this allowed the bombers to continue unmolested towards the American task force. The additional Wildcat fighters launched from the American carriers engaged these bombers in a running duel as they approached the task force. Radar had performed admirably. If radar had not given the American carriers sufficient time to launch additional fighters to defend the task force, the battle might have resulted in an overwhelming victory for the Japanese. However, there were too many Japanese aircraft for the American fighters to deal with. Lexington was hit by two aerial torpedoes as it continued to conduct flight operations. Several hours after the battle ended the Lexington exploded and had to be abandoned.

Both sides claimed victory, but a more accurate conclusion would be a tactical draw. The Japanese lost Shoho, the carrier Shokaku had been severely mauled with its flight deck ruined, and the airgroups from both Shokaku and Zuikaku had been decimated. This forced the Japanese carriers to withdraw, as they were unable to effectively 
engage in combat without their air groups. Without air support from the two attack carriers, the Japanese were forced to postpone the Port Moresby operation indefinitely. It was this deferral gave the Americans a strategic victory. 44

${ }^{44}$ Edwin P. Hoyt, Japan's War: The Great Pacific Conflict 1853 to 1952 (New York: McGraw-Hill, 1986), 283. 


\section{Chapter 4}

Midway

Admiral Isoroku Yamamoto, Commander in Chief of the Combined Japanese Fleet and the principal strategist for the Pacific war, saw the upcoming Midway operation as the key to the entire war and in March 1942 he stated:

In the final analysis, the success or failure of our entire strategy in the Pacific will be determined by whether or not we succeed in destroying the United States fleet, more particularly its carrier task forces - . . We believe that by launching the proposed operations against Midway, we can succeed in drawing out the enemy's carrier strength and destroying it in a Throughout the war, the Japanese underestimated the Americans and developed their strategy on the belief that the Imperial Japanese Navy was superior to that of the United States Navy. Japanese plans were elaborate, often consisting of several interconnected elements which would contribute to the overall success of the whole strategy. Each element would perform its task according to a precise time table. Taking Midway Island would force the American Pacific Fleet to sally forth from its safe haven at Pearl Harbor to "save face" and American honor. Once the American

$$
{ }^{45} \text { Ibid. , } 289 .
$$


Fleet had set sail to re-take Midway Island, the Japanese Navy would engage it in a final "show-down" surface battle. The Japanese believed they had sunk two carriers in the Coral Sea Battle. Therefore, only two American carriers remained in the Pacific to oppose them. The two aircraft carriers could be effectively neutralized by the four-attack class carriers of the Japanese task force and the Japanese air flotilla which would be based on the captured island of Midway. The possibility that the Americans might be reading the JN-25 operational code of the Japanese Navy hadn't even entered into the script of the Japanese battle plan. Once the American fleet was destroyed, the Japanese looked forward to getting on with the establishment of the "Greater East Asian Co-prosperity Sphere."

The battle would begin with an attack upon Dutch Harbor, an American military base in the Aleutians. The attack was a feint to draw attention away from the main thrust against Midway while, at the same time, the Aleutian islands of Attu, Kiska and Adak would be captured to eliminate the threat of any more land-based bomber attacks upon the Japanese Home Islands. The main thrust against Midway would be made by four Japanese attack carriers, Akagi, Kaga, Soryu and Hiryu. Their combined air strikes would neutralize aerial opposition from the island, which would then be bombarded by heavy cruisers during the night 
in preparation for an invasion by special marine units the following morning. The American fleet was expected to sortie the following day. When it arrived in the area of Midway Island, a Japanese surface force, including the Yamato with its eighteen-inch guns, would annihilate the American Fleet.

The Americans had broken the JN-25 code and knew the Dutch Harbor raid was a ruse. They also knew that Midway Island was the primary target, so the American Navy prepared for the Japanese onslaught. ${ }^{46}$ Fighters, dive bombers, torpedo bombers and even a contingent of Army Air Force B-26 Marauder medium bombers were sent to Midway to bolster the air defenses. Additional anti-aircraft guns, shore batteries, a regiment of United States Marines and an early warning radar set were sent to the small Pacific atoll. Three carriers, Enterprise, Hornet and a quickly repaired Yorktown, were dispatched to a location just north of the island to lie in ambush for the Japanese.

The battle began on 3 June 1942, at 0545 hours, with a Japanese carrier strike upon Dutch Harbor, Alaska. The seaplane tender Gillis picked up the incoming Japanese planes, which had flown off the carriers Junyo and Ryujo, on

\footnotetext{
${ }^{46}$ Ibid., 294.
} 
radar and sounded the alert. 47 When the Japanese bombers arrived over the little harbor, they were given a fierce reception from the alerted anti-aircraft gunners. The Japanese raid resulted in little damage to the American installation. The following day, in the horrible weather conditions typical of the Aleutian islands, a radar-equipped PBY discovered the Japanese northern task force. When the pilot of the Catalina visually sighted the Japanese carrier Junyo, he elected to attempt a daylight torpedo attack. His bravado provided the defensive gunners of the Japanese task force with a very large, slow flying target, and they promptly shot him down. Had the pilot of the radar-equipped "Cat" elected to shadow the Japanese task force, he could have vectored in a flight of six torpedo armed B-26 bombers to make the attack. ${ }^{48}$ This unsuccessful attempt to torpedo the Japanese carriers by flying boat was followed by a bomb run from a radar-equipped $B-17$ weather plane flying at an altitude of nine hundred feet. The Japanese ships were untouched by the American bombs. However, the pilot of the B-17 maintained radar contact and vectored in another flight of five B-26's. Perhaps, if the Army pilots had been experienced in torpedo attack procedure, their attack might

47Brian Garfield, The Thousand Mile War: World War II in Alaska and
the Aleutians (Garden City, NY: Doubleday, Inc., 1983), 6-18. ${ }^{48}$ Ibid. , 48. 
have been successful. But, for the first time, radar had been employed to seek out the enemy and to guide friendly aircraft to the attack. The object lesson would be successfully applied at a later time.

At 1500 hours on 5 May 15.12 , the Japanese made a final attack upon Dutch Harbor. Again, radar aboard the Gillis alerted the harbor defenses well before the enemy aircraft attacked. It also allowed the secret Army airbase at Umnak to scramble a squadron of $\mathrm{P}-4 \mathrm{OA}$ fighters to provide a warm reception for the Japanese. During the raid, three Japanese Zero fighters from the Ryujo attacked a PBY and forced it to land in the harbor. One of the fighters had an oil sensor cable clipped by a stray round from the defensive gunner aboard the catalina. The pilot of the zero, Petty officer Tadayoshi Koga, observed a large open field and decided to land in order to make repairs. His Zero landed and flipped upside down in what turned out to be a peat bog. The zero was recovered a few weeks later by the Americans and sent to the United states for evaluation. ${ }^{49}$ This captured Zero would become one of the best intelligence coups of the war as it was quickly restored to flyable condition and sent to the United states for evaluation. Experienced combat pilots flew the captured Zero and discovered a number of

\footnotetext{
${ }^{49} \mathrm{Jim}$ Reardon, Cracking the Zero Mystery (Harrison, PA: Stackpole Books, 1990), 80 .
} 
idiosyncracies which would provide American pilots with an advantage over the nimble Japanese fighter.

The use of radar to assist aircraft in locating an enemy force was far from perfect. The Dutch Harbor phase of the Midway Battle ended when a radar-equipped PBY sighted several Japanese carriers at anchor in the Bering sea. Immediately, six B-17 bombers were dispatched, two of them radar-equipped weather planes. Only after the attack was it discovered that the United States Navy had mistakenly reported the Pribilof Islands for Japanese carriers. ${ }^{50}$ It wasn't a failure of the radar which caused the embarrassing mistake, it was a human error in identification.

The Midway phase of the battle began at 0540 hours on 4 May 1942, when a radar-equipped PBY from Patrol Squadron Twenty-three (VP-23) flashed a warning of multiple contacts. A few minutes later the contacts were visually identified as three battleships, four cruisers and six or eight destroyers. At 0544 hours another radar-equipped "Cat" flashed a warning of many aircraft at one hundred miles inbound to the Island. Midway went on alert. When the early warning radar picked up the incoming enemy at 0556 hours, all aircraft on the island were scrambled. The early warning radar even provided surficient time for the morning

\footnotetext{
${ }^{50}$ Garfield, The Thousand Mile War, 48 .
} 
CAP to be brought down for refueling while fresh aircraft replaced. As soon as the fighters were refueled, they took off to engage the incoming Japanese bombers and fighters in a running battle. In the aerial engagement the F2A-1 Buffalo and F4F-3 Wildcat fighters were horribly outclassed by the Japanese Zero fighters, but the number of defending aircraft disrupted the Japanese bombers as they were making their bomb runs on the island airfield and other installations. The Japanese had only expected an insignificant aerial defense of the island. Due to the minimal amount of damage inflicted, the strike commander reported that a second strike would be necessary to neutralize the island defenses. 51

The American task force, with the knowledge that the battle had been joined, launched its strike aircraft. Unfortunately, human failure caused the battle to degenerate into a comedy of errors on both sides. American strike planes did not carry radar, so the Japanese carriers had to be located visually. The fighters which were to escort the lumbering TBD-1 Devastator torpedo bombers became separated from their charges. At 0700 hours, various aircraft from Midway began to make un-coordinated attacks upon the

\footnotetext{
${ }^{51}$ Robert Cressman and steve Ewing, "A Glorious Page in our History: The Battle of Midway 4-6 June 1942 (Missoula, MT: Pictorial Histories Publishing Company, Inc., 1990), 73.
} 
Japanese ships. The Army B-26 bombers, armed with

torpedoes, made a miserable showing. The United states Navy fared worse as five of the six brand new TBF-1 Avenger torpedo bombers were shot down without registering a single hit. 52

Vice Admiral Nagumo, commander of the Japanese carrier strike group, upon receiving the report that a second strike was required to neutralize Midway, surmised that the American bombers attacking his ships were coming from Midway. He ordered the planes of the second strike group, which were armed with torpedoes and armor piercing bombs intended for naval ships, to change the strike loads for a land attack. In the rush to rearm, ordnance was left on the hangar deck as new ordnance was brought from the magazines. The seeds for a disaster were quickly being sown. At 0726 hours, one of the cruiser search planes reported the presence of the American carriers. Admiral Nagumo quickly rescinded his order to arm for land targets and ordered the planes rearmed for surface targets. At this moment, the Midway strike aircraft were returning from the island. The decision was made to recover, refuel and rearm these strike aircraft before launching a strike against the American

\footnotetext{
1979), 21 .

52 Barrett Tillman, Avenger at War (Annapolis: Naval Institute Press,
} 
carriers.

When the lumbering torpedo planes from Torpedo Eight (VT-8) commenced their attack at 0915 hours, the Japanese CAP came down to engage them at wave top level. All available fighters from Akagi and Kaga were scrambled to defend the ships, and every Devastator in VT-8 was shot down without making a single torpedo strike. ${ }^{53}$ while the ungainly torpedo bombers were making their runs, the Dauntless dive bombers reached their push-over points, unseen by the Japanese. Without Japanese fighters to interfere, the American dive bombers made textbook attacks, laying their one-thousand-pound bombs squarely onto the encumbered flight decks of Kaga ( 4 bombs), Akagi ( 2 bombs) and Soryu (4 bombs). Hiryu, which had entered a rain squall, escaped the initial onslaught. In less than a minute, all three Japanese carriers were raging infernos, fueled by aviation gasoline and exploding ordnance. 54 During the attack, Hiryu launched a strike vectored to an American carrier by a snooper float plane from the Japanese cruiser Chikuma.

Aboard Yorktown there was an uneasiness. Somehow, the fourth carrier which had been reported had eluded the

\footnotetext{
${ }^{53}$ Lundstrom, First Team, 433.

${ }^{54}$ Ibid. , 433.
} 
initial air strikes. If the fourth carrier managed to get a strike airborne, the American task force could be in serious trouble. Lieutenant Commander oscar Pederson, fighter director officer aboard the Yoxktown, decided to augment the CAP of six Wildcat fighters with twelve more wildcats. One of the lessons learned by the Americans during the Battle of the coral sea was that more fighters were needed aboard the carriers. The new F $4 \mathrm{~F}-4$ wildcat variant, with folding wings, had reached the fleet just prior to the Midway operation. Therefore, the fighter contingents of all of the American carriers were increased from eighteen to twentyeight fighters.55 At 1158 hours, radar aboard Yorktown picked up bogeys inbound and climbing at twenty-three miles. Lieutenant Commander Pederson realized the contact had to be hostile, using the logic that if the inbound aircraft were returning friendly aircraft, then they would have been letting down to landing pattern altitude. The Japanese had been able to close to within twenty-three miles because they had flown at wave top level until they reached the horizon in order to remain under the radar scan pattern. 56

Lieutenant Commander Leonard J. Dow, fighter director officer aboard Enterprise, had also detected the approaching

\footnotetext{
${ }^{55}$ Ibid., 383.

56 Ibid. , 743.
} 
attackers, and he sent four wildcats to assist the fighters from Yorktown. Thanks to radar, twenty-two wildcats were at altitude to engage the Japanese strike on the Yorktown. Unfortunately, there weren't enough fighters to prevent Yorktown from taking several hits by bombs and torpedoes. As Yorktown was at the center of the battle, Lieutenant Commander Pederson had been given control over the air battle. The precedent had been established which would allow the fighter director officer who was closest to the enemy to assume tactical command of the air battle regardless of rank. 57 This procedure would become a standard throughout later carrier battles.

Although Yorktown was dead in the water, its radar continued to function and at 1232 hours the radar operator picked up more incoming aircraft at ten miles. The problem in picking up these intruders was due to cruiser-launched spotter aircraft cluttering the radar screen aboard Yorktown. At 1425 hours, the radar aboard the heavy cruiser Pensacola picked up incoming bogeys at thirty-five miles. The heavy cruiser sent a warning to yorktown. Lieutenant Commander Pederson called for help, but additional fighters were unavailable, since those which had participated in the earlier aerial battle were landing short of fuel and

$$
57 \text { Ibid., } 743 .
$$


ammunition. This last bogey was a flight of Japanese Kate torpedo bombers from Hiryu. Without friendly fighters to engage the enemy, the bombers were able to make their torpedo runs without interference. The yorktown took two more torpedoes which ended the proud carrier's participation in the battle. 58

Enterprise and Hornet launched their own air strikes while the battle raged around Yorktown. At 1658 hours, the combined air groups sighted Hiryu, which was in the process of launching a third strike, and attacked. Four onethousand-pound bombs hit Hiryu and the Japanese carrier became a raging pyre of exploding ordnance and burning aviation gasoline.

The grandiose plan to lure the American Navy out to engage in battle had worked flawlessly. Unfortunately, the wily Americans had not reacted as predicted; what was to have been a Japanese victory turned into a unprecedented disaster. The Japanese had lost four irreplaceable attack carriers along with their combat-experienced air groups. The Americans lost Yorktown, but gained invaluable experience in a new form of naval warfare by using aircraft to inflict maximum damage upon an enemy. The men who planned and implemented the aircraft carrier as a weapon of

${ }^{58}$ Ibid., 745. 
war were, for the most part, forward-thinking tacticians willing to try new concepts. The men of the Naval Air branch of the United States Navy embraced the electronic phenomenon of radar and introduced it to naval combat. The Battle of Midway forced both antagonists to realize that the battleship had been usurped by the aircraft carrier as the queen of naval combat. 


\section{Chapter 5}

\section{Guadalcanal}

The Battle of Midway is generally acknowledged by historians to have been the turning point of the Pacific war. However, it can also be demonstrated that a single battle early in a major conflict does not end a war. The Japanese, although stunned, were far from beaten. They still possessed a vast array of surface combatants, including the super battleships Yamato and Musashi. In addition to their remaining carriers, the Japanese could also call upon a number of aerial flotillas on island bastions in the Pacific. A new phase in naval warfare would exupt in the Solomon Islands campaign, a year-long series of bloody, face-to-face confrontations on the islands, on the surface of the sea, and in the air. In this campaign United States surface warships, cruisers, destroyers and eventually battleships would deploy radar, not only as a passive technology for early warning but as an overt method to locate and destroying the enemy.

The United States Navy didn't allow the Japanese much time to recover from their defeat at Midway. On 7 August 1942, elements of the United States Marines swarmed onto the 
islands of Tulagi and Guadalcanal in the Solomon Archipelago. Not only did the Americans surprise the Japanese, but they captured a nearly completed airstrip. Guadalcanal was to have been a key outpost along the Pacific ring of islands which formed the inner border of Japan's newly acquired empire. Suddenly, with a spear-like thrust, the Americans had rudely established their presence. If the American presence could not be dislodged, it would become a gangrenous wound which would infest the entire island archipelago and eventually threaten the vital harbor and air bases at Rabaul.

When the Marines captured the air base on Guadalcanal, they also discovered a passive, early warning radar set, still warm and in operating condition. The set was quickly loaded aboard a ship for transport to the United states where it could be evaluated by experts. ${ }^{59}$ subsequently, a small team of enlisted electronic specialists would be trained and sent to the Solomons to ferret out and destroy any additional radar sets the Japanese might deploy.

The newly acquired airfield on Guadalcanal was officially named Henderson Field by the Americans and given the code name "Cactus." It became the focal point of the struggle between the United States Navy and the Imperial

\footnotetext{
${ }^{59}$ Knott, Black Cat Raiders, 114.
} 
Japanese Navy. Savo Sound, the body of water which separated Guadalcanal and Tulagi, became "Iron Bottom Sound" because of the large number of ships from both sides which were sunk there in the nocturnal duels between the surface combatants.

The Japanese were quick to respond to the American incursion. On 8 August 1942, twenty-seven Betty bombers flew from their bases around Rabaul to attack the American transports which were anchored off the landing beaches. The American amphibious task force was being protected by aircraft from the carrier Saratoga, and its radar picked up the incoming raiders. The CAP of Wildcat fighters was vectored to intercept. To the Americans' surprise, the Japanese bombers were escorted by Zero fighters equipped with gasoline drop tanks which gave them a phenomenal combat radius of 650 miles. Fortunately, the American pilots had previously encountered the Zeros in the Coral sea and Midway battles. American pilots had also received training on the quirks and nuances learned from the Zero captured at Dutch Harbor. This intelligence would be used to their advantage. 60 In the first day of aerial combat over Guadalcanal the Japanese lost thirty out of fifty aircraft. Guadalcanal would become a blood-letting experience for the

\footnotetext{
${ }^{60}$ Ibid., 61.
} 
Japanese airmen, an experience from which they would never recover.

The problem with air cover during this period of the Pacific war was that the American carriers could only provide a protective air umbrella over Guadalcanal during the hours of daylight. At night the Japanese were free to send their cruisers and destroyers down New Georgia Sound, which was quickly dubbed "The slot," to attack the Americans. The Japanese quickly took advantage of this opportunity. On the night of 9 August 1942, five heavy cruisers, Chokai, Kako, Aoba, Kinugasa, Furutaka, and a light cruiser, Yubari, slipped past the American destroyer Blue which was standing watch at the entrance to savo sound. The Blue had been fitted with radar, but apparently nobody aboard the American destroyer was watching the radar scope as the Japanese warships slipped past the American "watch dog" and entered savo sound. In the waters around Savo Island, which lay between the two larger islands of Guadalcanal and Tulagi, an Allied naval force of five American cruisers, Vincennes, Chicago, Astoria, Quincy and San Juan, stood watch with two Australian cruisers, Hobart and canberra. In addition to the cruisers, there were a number of destroyers which were also radar-equipped. 61

\footnotetext{
${ }^{61}$ Hamilton, War at Sea, 144.
} 
Just before dawn, the Japanese cruisers initiated their attack with the deadly "long lance" torpedoes, quickly followed by a deadly barrage from their eight-inch naval guns. Within minutes, Vincennes, Astoria, Quincy, Canberra, and the destroyer Jarvis were sinking wrecks. Chicago was badly mauled and could no longer fight. The Americans knew the Japanese were coming through numerous reports from coast watchers, most of whom were Australian plantation owners who visually kept watch from islands adjacent to The slot, and from radio traffic intercepts. The Americans should have known that the Japanese would attack, probably, at night. The radar aboard one or more of the Allied ships should have picked up the approaching enemy vessels. However, it is quite possible that the mass of Savo Island masked the radar returns from the Japanese warships. None of the radars aboard any of the Aliied vessels detected the Japanese as they entered Savo Sound; radar, in its opening debut as a weapon for naval surface combat, was a complete failure. 62 The Japanese commander, Vice Admiral Gunichi Mikawa, presented historians with another quandary. He had decimated the ships which protected the prize of the entire operation, the fat transports and cargo ships of the American amphibious force. Unprotected, the task of

$$
62 \text { Ibid., } 144
$$


slaughtering these helpless ships would have only taken the Japanese cruisers a few ininutes, but Admiral Mikawa elected to turn around and retire from the scene. It is quite probable that the Japanese admiral had a healthy respect for American air power and did not want his ships to be caught within range of the American carriers during daylight hours.

The naval seabee construction workers worked frantically to make the captured airstrip serviceable for aircraft and by 17 August 1942, the little airfield was declared operational. That same day nineteen wildcat fighters assigned to VMF-223 landed on the Marston matting of interlocked, perforated metal plates. The fighters were followed by twelve Dauntless dive bombers assigned to SCMB232. During the night the Japanese landed one thousand crack troops from the "Ichiki" division under the cloak of darkness and attacked the United States Marines in a vicious, unrelenting, often hand-to-hand battle. The fighting lasted two days and ended with the "Ichiki" troops being wiped out. On 22 August 1942, the 67th Fighter Squadron of the Army Air Force landed their P-400 Aircobras on the little airstrip. Henderson Field was destined to become a conglomerate airbase, hosting aircraft from the Army, Marines and Navy while it served as an unsinkable aircraft carrier.

Activity around Guadalcanal quickly developed into a 
strange ritual. By day, the Americans would rush in supply ships to be quickly offloaded so they could retire before nightfall to safer waters. The Japanese would rush down The slot with fast destroyers, converted into troop/cargo transports, to arrive off the northern beaches after nightfall. There the destroyers would quickly offload troops and supplies and depart so they would be safe from aerial attack by daylight. The nightly excursions of the Japanese up and down The slot were referred to as the "Tokyo Express." However, the Japanese tired of this game and decided to recapture the Guadalcanal airstrip.

A task force was organized which included the light carrier Ryujo and the attack carriers Shokaku and zuikaku. The carriers were to protect four large transports carrying 1,500 troops of the 17th Japanese Army. In addition to the carriers, two powerful battleships, Haruna and Kongo, each mounting fourteen-inch naval guns, accompanied the force to provide fire support. ${ }^{63}$ Australian coast watchers reported the Japanese task force as it moved down The slot on 22 August 1942 .

Both antagonists realized that a classic daylight carrier battle was brewing when air elements from Enterprise and Saratoga caught the light carrier Ryujo in the open and

${ }^{63}$ Hara, Japanese Destroyer Captain, 260. 
destroyed it on the 23 rd of August. Rear Admiral Fletcher realized that the Japanese would counter-attack, so he elected to fight a defensive battle by ordering a protective CAP of Wildcat fighters into position over the American task force. When radar aboard the Enterprise picked up the Japanese air strike, the fighter director officer vectored his charges to a routine intercept. While the battle raged over the task force, another bogey was seen on the radar screen. The Japanese were becoming aware of the offensive potential of radar and were attempting to slip a formation of Vals and Kates under the early warning radar beam. The Japanese formation was too large for the American fighters to stop and a number of the enemy aircraft managed to slip through the defensive screen. These bombers ran into a wall of anti-aircraft gunfire from North Carolina, one of the newest American battleships. Japanese aircraft literally fell from the sky, destroyed by the highly accurate fiveinch gunfire which was being controlled by a new radar fire control system. Despite these defensive measures Enterprise was hit by three bombs and had to retire. 64 Its air groups simply flew to Henderson Field to augment the "Cactus Air Force" squadrons on Guadalcanal. The Battle of the Solomon Islands ended with the Japanese retiring after

${ }^{64}$ Hamilton, War at Sea, 150. 
losing ninety aircraft, a light carrier and hundreds of men. For the Japanese, Guadalcanal had become a point of honor and retaking the little island became an obsession. As the struggle for control of Guadalcanal continued, the American carriers were destroyed and/or forced to retire from the field of battle. Enterprise had been forced out of the action during the battle on 22 August. Saratoga caught a Japanese torpedo on the 23 August. Wasp was sunk by a submarine on the 15 september. On the island proper, the Japanese threw themselves against the United States Marines in desperate "banzai" charges against a low ridge which overlooked the airfield. "Bloody Ridge" became a by-word in the vocabulary of the United states Marine Corps.

On the night of 11-12 October 1942, TF-64, under the command of Rear Admiral Norman Scott, arrived with a flotilla of four cruisers and five destroyers. Three of the cruisers, Boise, Salt Lake City and Helena, were equipped with the latest form of SG radar. The flagship, san Francisco, carried the older SC radar, but it had been fitted with the new fire control radar which was linked to the secondary, five-inch, batteries. Admiral Scott's orders were to intercept a Japanese task force which was due to arrive during the night in an attempt to reinforce the Japanese troops on Guadalcanal. In the Japanese van were the cruisers Aoba, Kinugasa and Furutaka. At 2235 hours, 12 
October 1942, the radar aboard Helena picked up the approaching Japanese ships sailing fourteen miles off cape Esperance. 65 Helena notified San Francisco and requested permission to fire, but Admiral scott refused to give the order until the vessels could be confirmed as enemy. At 2346 hours, Helena had identified the enemy ships visually and opened fire. San Francisco also picked up the Japanese ships and engaged the enemy with the new radar-controlled five-inch guns. Its five-inch projectiles were "dead on" at a range of five thousand yards. Two of the Japanese ships were abruptly set ablaze. The cruisers in the American van began firing upon the burning Japanese ships with their eight-inch and six-inch guns. The Japanese had been trained to wait until the enemy attempted to illuminate their targets with search lights. Search light beams made excellent beacons upon which the Japanese could register their counter-fire. Since a radar beam cannot be seen, the Japanese were virtually blind in the inky blackness of the South Pacific night and the Japanese counter-fire was difficult to direct. Finally, Fubuki saw Boise and engaged. This attracted the attention of the heavy cruiser San Francisco, and the it provided accurate counter-fire from the radar-controlled five-inch batteries. At the same time,

\footnotetext{
${ }^{65}$ Ibid. , 157.
} 
information supplied by the fire control officer allowed the larger eight-inch batteries to register onto the enemy vessel. The battle ended with Furutaka and Fubuki being sunk, while Aoba and Kinugasa were severely mauled. The Americans had one destroyer, Duncan, and two cruisers, Boise and salt Lake city, damaged. The radar-linked fire control system of the American cruisers had proven itself in a nocturnal surface action for the first time. All that was needed was a little more practice. ${ }^{66}$

The night action off Cape Esperance forced the American flotilla to retire to repair battle damage. This effectively stripped the Americans on Guadalcanal of their defense from the sea. Again, the Japanese took advantage of the opportunity. On the night of 12-13 October 1942, two Japanese battleships, Kongo and Haruna, slipped into the Savo sound and hurled nine hundred fourteen-inch shells onto Henderson Field. Of the ninety-three available aircraft on the field, only forty-two were salvageable the next morning. Worse, most of the supply dumps, with their precious fuel and ordnance, had been destroyed. 67 The next night, 1415 October, two heavy cruisers, Myoko and Maya, repeated the performance with a bombardment of eight-inch projectiles

\footnotetext{
${ }^{66}$ Hanson, USS San Francisco, 50.

67 Hamilton, War at Sea, 158-159.
} 
upon the island airstrip. Without adequate aircover from Henderson Field, the Japanese were able to reinforce their garrison on Guadalcanal. Had the Japanese attacked in force, they might have pushed the American Marines into the sea. The Americans were quick to reinforce Henderson with sixty aircraft. At sea, Enterprise and Hornet, accompanied by the South Dakota, one of America's newest battleships, moved into position on 25 october 1942. Supporting the American task force were six cruisers and fourteen destroyers.

The Japanese believed they had only to support their garrison on Guadalcanal in order to take the airstrip, but they decided to insure against failure. A powerful task force moved down The slot. Facing the Americans were the carriers Shokaku, Zuikaku, Junyo and Zuhio. The bombardment force included the battleships Kongo, Hiei, Kirishima and Haruna. In addition to the primary vessels the Japanese also sent ten cruisers and twenty-nine destroyers. ${ }^{6}$ The battle of the Santa cruz Islands was primarily a carrier duel which lasted from the 26 th through the 27 th of October. Zuhio and Shokaku were put out of action, while Hornet was sunk. Enterprise, although hit, remained operational.

\footnotetext{
${ }^{68} \mathrm{Helmut}$ Pemsel, A History of War at Sea: An Atlas and Chronology of Conflict at sea from Earliest Times to the Present, trans. Major, D.G. Smith (Annapolis: Naval Institute Press, 1975), 138.
} 
During the aerial battle the South Dakota shot down twentysix Japanese aircraft, a credit to its radar-linked antiaircraft fire control system. ${ }^{69}$ Although they had thought they had victory in their grasp, the Japanese were once more forced to retire from the battle and their obsession to retake Guadalcanal turned to frantic desperation.

The Japanese initiated a plan to capture the island of Guadalcanal on 12-13 November 1942 by sending a powerful bombardment force to repeat the performance of 12-13 October and 14-15 october. Once the airfield was neutralized, eleven transports would land Japanese Army troops on the island and overwhelm the American Marine defenders. In the Japanese van were the battleships Hiei and Kirishima. The cruiser Nagara and fourteen destroyers sailed as escort. The Japanese did not expect to meet any resistance from their naval opponents during the night, but the Americans had positioned a strong cruiser force in the area: the heavy cruisers San Francisco and Portland, the anti-aircraft cruiser Atlanta, armed with sixteen five-inch guns in twin mounts, 70 and the light cruisers Helena and Juneau. Three destroyers also escorted the blocking force. During the early morning, at 0124 hours on 13 November

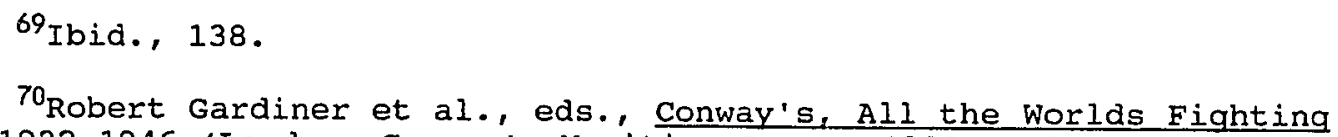


1942, American radar picked up the Japanese force as it entered Savo Sound. Unfortunately, San Francisco was still equipped with the inferior SC radar and Rear Admiral Daniel Callaghan had issued orders which prevented any American ship from operating independently. By the time the American Admiral was aware of the Japanese presence, the enemy was attacking. The problem was not one of ineffective radar. The problem was the reluctance of the American commander to accept and trust the electronic technology.

The first casualties were the American destroyers. Then, San Francisco was caught between Kirishima and Hiei. In the melee that followed, the only way to identify friend from foe was by visual means; the radar fire control systems could only be employed once the enemy had been identified. The resulting melee lasted twenty-five minutes with the Atlanta and four American destroyers being sunk. The Japanese lost only two destroyers, but the Hiei was badly mauled. As the Hiei attempted to limp northward to safety on the morning of the 13th she was caught and sunk by the "Cactus Air Force." The American cruiser Juneau, which had also been damaged on the 12th, was sunk by a Japanese submarine on the same day as the Hiei. ${ }^{71}$

Conditions for the Japanese on Guadalcanal were

\footnotetext{
${ }^{71}$ Hamilton, War at sea, 163.
} 
desperate. The Japanese found it difficult to reinforce their island garrison. It was imperative, if the Japanese were to force the Americans off the island, that the Japanese garrison had to be augmented with an overwhelming force of fresh men and supplies. Therefore, in spite of their loss of the Hiei, the eleven large transports of the Japanese amphibious assault force continued to move down The slot under the protection of eleven Japanese destroyers. At the same time, South Dakota accompanied by Washington, steamed northward from Noumea to reinforce the naval units which had been so badly mauled on the 12th. At 0830, the Japanese reinforcement transports were sighted 150 miles northwest of Guadalcanal. Enterprise launched an air strike which was augmented by bombers flying from Henderson field and B-17's from Espiritu Santos. Seven of the eleven Japanese transports were sunk. The survivors of the sinking transports were strafed in the warm South Pacific waters, while the four surviving transports beached themselves in an attempt to discharge their passengers. They too, were bombed and strafed. The massacre of the 13 th was one of the worst disasters suffered by the Japanese during the entire war. 72

In spite of their horrendous losses, the Japanese

$$
72 \text { Ibid., } 166 .
$$


remained obsessed with recapturing Guadalcanal. They attempted once more to bombard Henderson Field during the night of 14 October 1942. Vice Admiral Nobutake Kondo sailed his bombardment force, which now consisted of the Kirishima, two heavy and two light cruisers, and nine destroyers into Savo Sound. But Rear Admiral Willis "Ching" Lee had arrived with the battleships Washington and south Dakota to patrol the waters between Cape Esperance and Savo Island. ${ }^{73}$ Escorting the battleships were the heavy cruiser Pensacola and four destroyers. At 2300 hours, radar aboard the Washington picked up the Japanese cruiser Sendai. This time an American admiral was in charge who had familiarized himself with the new electronic technology. Washington open fired and Sendai attempted to retreat under a covering screen of smoke. At the same time the American destroyers fired on two Japanese destroyers. Their activity revealed their positions to the Japanese cruiser Nagara. In seconds preston was sunk, Walke was set afire and Benham lay dead in the water with her bow blown off. In spite of the advantage held by the American Navy because of radar, the Japanese were still masters at nocturnal naval-in-fighting. South Dakota took a hit which destroyed an electrical

\footnotetext{
${ }^{73}$ Ivan Musicant, Battleship at War: The Epic Story of the USS Washington (New York: Harcourt Brace Jovanovich, Publishers, 1986), 119.
} 
circuit junction box. This resulted in the loss of all steering control, and the new American battleship steamed at flank speed right through the Japanese van, firing what guns she could. ${ }^{74}$ The Japanese were ecstatic. It was a oncein-a-lifetime opportunity! All guns in the Japanese van locked onto South Dakota and commenced firing. The Japanese aboard Kirishima, intent upon destroying the American battleship, didn't see Washington approaching from the opposite side. Radar aboard Washington locked on to Kirishima at a range of four miles. Admiral Lee ordered a full salvo from his sixteen-inch guns which straddled the Japanese battleship. Then the radar-controlled, secondary five-inch batteries commenced firing with uncanny accuracy. The second salvo of sixteen-inch projectiles from Washington hit Kirishima, as did the third and fourth. Kirishima became a burning hulk and the secondary batteries from Washington took on the cruisers Atago and Takao. At 0030 hours, Kirishima sank from sight. ${ }^{75}$ South Dakota escaped from its momentary vulnerability with relatively little damage.

It can be argued that the Battle of Guadalcanal on the 13 th and 14 th of october 1942 was the real turning point of

\footnotetext{
${ }^{74}$ Ibid. , 128.

${ }^{75}$ Ibid. , 133.
} 
the Pacific war. This was the last desperate attempt by the Japanese to dislodge the Americans from Guadalcanal. The electronic phenomenon of radar had proved itself to be a deadly weapon when wielded by a warrior proficient in its use.

During the after-action conference it was decided to move the radar plot aboard Washington to a position next to the command post. The innovative sailors also mounted a large sheet of clear plastic vertically from the overhead in the battleship's command post. Onto this sheet of plastic, concentric rings were etched at specific distances from the center point which represented Washington. The circular polar chart was then quartered for easy determination of bearings to a contact while the radar plots were registered with grease pencil. This system, the forerunner of the modern command and control (CIC) center, was quickly adopted as a standard throughout the United States Navy. 76 New procedures were also established for surface action. Destroyers would no longer trail the cruisers. They would henceforth be placed ahead of the cruisers where they could use their radar to initiate an early torpedo attack. Once the torpedoes were launched, the destroyers would clear away to allow the cruisers to fire upon the

$$
{ }^{76} \text { Ibid., } 148 .
$$


enemy with larger caliber guns. The use of search lights was forbidden. It had been established that the beams of brilliant light made excellent beacons for registering counter-fire. Every task group would also include at least one ship with the newer SG radar and the use of the tactical, talk-between-ship (TBS), voice net was to be standardized. 77

The battle of the $13 \mathrm{th}$ and $14 \mathrm{th}$ of November had forced the Japanese to take desperate measures to resupply their Guadalcanal garrison. The troops were dying from a lack of food, medicine and ammunition and a tactic was devised to resupply them by loading supplies onto the decks of the faster destroyers. The destroyers would rush down The slot to arrive off the Japanese-controlled beaches at night; but unlike earlier resupply efforts, this time the destroyers would not stop to offload the supplies. The supplies, which were attached to flotation devices, would be pushed over the side of the destroyer as it passed by the Japanesecontrolled beaches in the hope that some would drift ashore with the tide. As soon as the task was completed the destroyer would turn about and steam northward, to be out of reach of the American airpower by daylight. ${ }^{78}$ It was a

\footnotetext{
77 Ibid., 149.

78 Hara, Japanese Destroyer Captain, 161.
} 
plan that did not always work to the Japanese advantage, but on some nights the gods favored the Japanese. During the night of 30 November 1942, Rear Admiral Raizo Tanaka, commanding a "Tokyo Express" resupply effort, sailed through the narrow waters of Tassafaronga strait with eight fast destroyers: Takanami, Naganami, Makinami, Oyashio, Kuroshio, Kagero, Kawakaze, and Suzukaze. Four heavy cruisers, Minneapolis, New orleans, Northampton, Pensacola, the light cruiser Honolulu and several destroyers patrolled the strait as TF-67. The commander of TF-67, Rear Admiral Carleton Wright, was operating under the newly established procedures for surface combat. In theory, the procedures had merit, but apparently nobody had bothered to rehearse the procedures prior to engaging in a live surface action. At 2106 hours, radar aboard the Minneapolis picked up the leading Japanese destroyer Takanami at a range of twenty-six thousand yards. The Japanese, who were virtually blind at night without the use of radar, proceeded to their cargo release point, unaware of the superior enemy force bearing down upon them. At 2115 hours, Takanami visually picked out three American destroyers and, without waiting for permission to attack, launched her torpedoes while warning her companions. ${ }^{79}$ one minute later, the American

$$
{ }^{79} \text { Ibid., } 162 .
$$


destroyer Fletcher, which carried the newest radar equipment, picked up the enemy van at a range of seven thousand yards. The Fletcher was unaware that the Japanese torpedoes had already been launched. The Japanese destroyers had slowed to twelve knots in order to discharge their cargos. For the American destroyers, which had preceded the cruisers, it was a classic setup for a torpedo attack. Fletcher asked permission to initiate the attack. For some unknown reason, Admiral Wright refused. Five minutes after Fletcher requested permission to attack, Admiral Wright gave the order, but it was too late. The Japanese destroyers had already gone to full emergency power. The Japanese generally emerged victorious in any nocturnal combat with the Americans when the advantage of radar was negated. The Battle of Tassafaronga Strait was a classic example of just how deadly the Japanese Navy could be in a night surface action.

The American torpedoes were fired at an enemy retreating faster than the American torpedoes could travel. Each American cruiser selected its target by radar. The order was given to fire, and each cruiser in the American van complied. The projectiles from all of the cruisers headed, dead on, for their selected victim. The lead Japanese destroyer, Takanami, vanished in an enormous explosion. The remaining destroyers in the Japanese van 
reacted by launching "long-lance" torpedoes. Within minutes, Minneapolis lost sixty feet of her bow and went dead in the water. New orleans took a torpedo while attempting to avoid Minneapolis and was cut in half. Pensacola attempted to avoid New orleans and took a torpedo. Northampton was hit by two torpedoes and immediately sank. Honolulu, which had escaped the initial disaster, retreated while firing upon two American destroyers, thinking them to be the enemy. 80

Radar did not cause the disaster in Tassafaronga strait. The radar had worked perfectly! Again, the cause lay clearly in the lap of the commanders who either mistrusted the electronic technology and/or were inept, due to inexperience and lack of training in using the technology. If the American Navy had established a training program on radar combat procedure for the admirals who were being sent to the fleet, the outcome of the numerous surface battles around Guadalcanal might have been more favorable. Instead, the American admirals were sent into battle without any indoctrination in electronic combat tactics. The lessons of using radar had to be learned on-the-job under live combat conditions. Even if the admiral survived a surface action, there was no guarantee that his newly

$$
{ }^{80} \text { Ibid., } 164 .
$$


acquired knowledge would be put to use. Admirals who lost a battle were often re-assigned to non-combat desk jobs. The knowledge gained during combat was no longer put to use. After all, nobody wants to talk to a loser! 
Chapter 6

Black Cats

During the struggle for control over Guadalcanal, radar was adapted to a new role using the least likely and most passive of military organizations, the naval patrol squadrons with their large lumbering flying boats. At the start of World War II, the PBY Catalina flying patrol boat was considered to be obsolescent. The production line at the Consolidated plant had not been dismantled and "combat expediency" allowed construction of the Catalina to continue. The "Cats" were equipped with air-to-surface radar which gave them the ability to detect objects at night and a new radar altimeter to provide the pilot with a precise height above the surface of the ocean. The PBY could also carry a prodigious pay load; a crew of five or six, the air-to-surface radar, two aerial torpedoes or several five-hundred-pound bombs mounted under the wings and it could remain aloft for extended periods of time. Unfortunately, in the South Pacific the Catalina was a "sitting duck" for any Japanese fighter that caught it during daylight hours. Because the air crews couldn't fiy by day, and the PBY could remain aloft over The slot from 
dusk to dawn, the crews decided to fly by night. The idea to convert the "Cat" from a passive observation platform into a deadly killer of ships occurred at 0200 hours on 16 October 1942. A radar-equipped PBY encountered a Japanese ship in The slot and attempted a night torpedo attack. The attack failed, probably because of faulty torpedoes, a problem which plagued the American Navy during the early months of the war. However, this time the pilot of the "Cat" called for help. A second radar-equipped PBY made its run at a height of fifty feet above the water and put a torpedo into the enemy vessel. 81 Four days later, two flying boats from VP-51 caught a covey of four Japanese ships moving down The slot. The "Cats" were only armed with bombs and the results were not spectacular, but one bomb hit a Japanese cruiser. In the Solomon Archipelago, the Catalina flying boat was about to write a new page into aerial history.

VP-11, a sister patrol squadron to VP-51, employed their "Yankee ingenuity" and painted their "Cats" with a mixture of lamp-black and soap. The result was a large flying boat painted a light-absorbing black, with a powerful search-light mounted on one wing and four .50-caliber, machine guns mounted in the bow anchor compartment. From

\footnotetext{
${ }^{81}$ Knott, Black Cat Raiders, 68.
} 
sundown to sunup the radar-equipped "Black Cats" prowled the skies over The slot. 82 A typical "Black Cat" sortie consisted of three PBY Catalinas, flying in a loose formation at an altitude from fifteen hundred to two thousand feet. The "Cats" flew a rough triangular pattern which began over Savo Island, extended to Buraku Island, then north to Korigole Harbor on San Isabel Island, southeast across Indispensable strait to Cape Astrolab and over the northeastern tip of Malaita where the airborne "pride" would return to Savo Island. Three circuits of this "mike pattern" would be made before the "Cats" retired for the night. 83 If one of the "Cats" happened upon a victim in The slot, the pilot would shut off his engines and silently glide to an optimum position for launching his torpedoes. The flat-black color scheme made the "Cat" blend into the surrounding black of the nearby islands while the radio altimeter allowed the PBY to fly at a precise height over the surface of the water. If there were any Japanese float-equipped fighters prowling on their own in the darkness, it would be almost impossible for the Japanese pilots to attack the slow flying PBY because the Japanese pilots would be flying without a visual reference to a

\footnotetext{
${ }^{82}$ Ibid., 71.

${ }^{83}$ Ibid. , 96.
} 
horizon. Without a horizon to maintain their depth perception, the enemy pilots risked flying into the water or a nearby island. As the "Black Cat" reached the torpedo release point, the pilots would turn on the searchlight to effectively blind anyone aboard the Japanese ship. While the "Cat's" engines were restarted, the four .50 caliber machine guns would rake the victim's decks, and the torpedoes would be released. Moments later, the nearly invisible flying boat would fly over the victim at masthead height while the torpedoes detonated against the side of the ship's hull. The attack took less than a minute. Survivors from the stricken vessel would swear they had been sunk by one of the American patrol-torpedo (PT) boats because the attack profile was almost identical.

As the fighting in and around Guadalcanal continued, the Black Cat squadrons were called upon to perform multiple nocturnal roles. The radar-equipped $\mathrm{PBY}$ 's acted as spotters for cruiser bombardment of Japanese installations, night intruder missions, ferret missions and even nocturnal harassment flights over Japanese positions on the island.

A typical intruder mission occurred on 22 October 1942. Three "Black Cats" from VP-11 were sent on a mission from Espiritu Santos to investigate a report of Japanese shipping in Tonelei Harbor, on the island of Bougainville. The flying boats carried a mixed load of torpedoes and bombs. 
After using the radar to guide them to the mouth of the harbor they initiated torpedo attacks from a height of fifty feet. Two Japanese cruisers were hit by torpedoes and bombs, a destroyer was sunk and one transport was also damaged by a torpedo. The Japanese were stunned, for they had no clue as to what had hit them. 84

The Japanese began to send one or more bombers to Guadalcanal to harass the American Marines at night. Each bomber would fly over the Marine positions alone with unsynchronized engines. The nocturnal harassment bomber was nicknamed "Washing-machine Charlie" by the Marines because the noise of the engines disrupted the sleep of the men below. At the same time, small anti-personnel bombs would be dropped to add to the woes of the defending Americans. The "Black Cat" squadrons decided to retaliate and the air crews of the nocturnal flying boats collected beer bottles by the case load. The empty bottles were loaded aboard the Catalinas and during the night the nearly invisible airplane would fly over the Japanese Iines to drop small

fragmentation bombs while the crew gleefully tossed the collection of glass bottles out the waist hatches. The beer bottles whistled as they fell, just like a bomb, and would shatter upon hitting the ground. No doubt, more than a few

${ }^{84}$ Ibid., 77. 
Japanese soldiers were hit by the flying shards of glass shrapnel, along with deadly shrapnel from the real fragmentation bombs. The Marines stationed on Guadalcanal referred to "Black Cat" response to "Washing-machine Charlie" as "Louie-the-Louse." Although the nightly harassment flights did little damage to the enemy, they boosted the morale of the American Marines on Guadalcanal.85

The Japanese surrendered Guadalcanal by default and removed the last of their remnant garrison off the island by February 1943. The Japanese strategy to was defend the Solomon archipelago island by island, forcing the Americans to expend material and lives until the United States would no longer want to continue the war. The problem for the Japanese was to supply their island garrisons. They couldn't move ships down The slot during the daylight hours, and at night something unknown but very deadly waited to pounce upon any ship that moved. The Japanese solution was to use a motorized, flat bottom daihatsu barge to re-supply the island garrisons. These fast barges were approximately fifty to sixty-five feet in length and began to see service in March 1943. The daihatsu also enabled the Japanese to move their supplies down the island chain in dispersed

$$
{ }^{85} \text { Ibid., } 71 .
$$


groups which minimized their losses. The barges would hole up during the day in a concealing bay or inlet to wait. Then, the daihatsu would venture out at night, their shallow draft allowing them to hug the shoreline of an island so that their radar return would be masked by that of the island. The American response to the daihatsu was to deploy the PT boat, armed with a $37 \mathrm{~mm}$ rapid-fire cannon on the bow, a $40 \mathrm{~mm}$ rapid-fire cannon on the stern, and the standard two twin-mounted .50 caliber machine guns. The PT boats carried their usual complement of four torpedoes, just in case they happened upon larger game. What made the PT boats deadly adversaries for the daihatsu was a light-weight radar set. 86

In the South Pacific night, the Japanese daihatsu was virtually invisible against the black silhouette of an island, but the fast barge had to cross open water between the islands. The American PT boats simply positioned themselves in a channel between two islands and waited. As the Japanese barge attempted to cross the open water, the PT boat would pick it up on radar and initiate a sudden, vicious attack with rapid-fire cannons and machine guns. The attack wasn't without hazards, for the Japanese often armed their barges with $40 \mathrm{~mm}$ anti-aircraft guns.

\footnotetext{
86 William Breuer, Devil Boats: The PT War Against Japan (New York: Jove Books, 1988), 97.
} 
The "Black Cats" considered the Daihatsu barges unworthy of their attention and their nocturnal excursions over The slot continued unabated in the search of larger prey. On 12 July 1943, a radar-equipped PBY on patrol over The slot detected a Japanese task force moving southward. The enemy force consisted of five vessels, which were moving too fast to be typical for a group of cargo or transport vessels. The pilot of the "Cat" surmised that he had located a small group of Japanese warships. Although the pilot of the PBY could have initiated an attack on his own, he was also aware that an American task force, which included the heavy cruiser Honolulu, was in the vicinity. The pilot of the PBY contacted the American task force and vectored it into position to ambush the Japanese force, which included the heavy cruiser Jintsu and five destroyers. This time the American surface units used radar effectively while the PBY circled over the battle to act as an aerial spotter for the cruiser gunfire. 87 These co-operative actions were not the norm for the "Black Cat" squadrons. They preferred to attack in single or multiple plane sorties, using torpedoes against Japanese shipping. The nocturnal patrol squadrons scored heavily. During the month of October 1943, a single "Black Cat" squadron, VP-33, sank 
a forty-three Japanese ships totalling 103,500 tons and damaged twenty ships totalling 53,500 tons. 88

The Japanese began to deploy their own primitive form of early warning radar by late summer, 1943. In retaliation the special "ferret" teams, which had been organized and trained in response to the captured Japanese radar set on Guadalcanal, were assigned to fly with the "Black cats" on special missions to detect Japanese radar emissions. once a radar site had been located, the task of the radar-equipped PBY was to destroy the enemy electronic equipment. During the night of 8 september 1943, a VP-54 "Cat", while flying a ferret mission, detected radar emissions emanating from Poporang Island, just south of Bougainville. The "Cat" attempted to destroy the radar site by bombing, but discovered that the Japanese had also set up a heavy concentration of anti-aircraft guns. The anti-aircraft gunfire was accurate enough to drive off the prowling "Cat"; but because the enemy position had been pin-pointed, it was a simple task to mount an air strike the following morning by a squadron of Aircobra fighter-bombers. The enemy radar site was quickly and destroyed. 89

\footnotetext{
${ }^{88}$ Ibid., 172 .

${ }^{89}$ Ibid., 115.
} 
Chapter 7

Night fighters

Radar was one of the most rapidly developing technologies of World War II, particularly in the adaptation of radar to the use of night fighters. The impetus to wed radar to a night-combat fighter was directly related to a critical need in Britain for defense against the German Luftwaffe. When the Luftwaffe failed to eliminate the British Royal Air Force (R.A.F.) during the Battle of Britain in 1940, it turned to nocturnal bombing raids upon the city of London and the outlying urban areas. At the time airborne intercept radar was still in an embryonic developmental state. The British were desperate for some means to defend against the German bombers which were raiding London during the night. In May 1940, as a stop-gap defensive measure the R.A.F. pressed the Boulton-PauI Mk.I Defiant into service as a night fighter. The Defiant was armed with four .303 Browning machine guns mounted in a power-driven dorsal turret located aft of the pilot. 90

${ }^{90}$ Enzo Angelucci, Paolo Matricardi and Adriano Zannino, eds, The Rand McNally Encyclopedia of Military Aircraft 1914-1980 (New York: The Military Press, 1980), 222. 
The pilot of the Defiant was required to locate an enemy aircraft visually before he could maneuver his fighter into a position where his rear gunner could engage the German bomber. Without radar the pilot of the Defiant groped about in the dark while the glare of searchlights and the fires of the burning city blinded him. It was no surprise that the Defiant was remarkably unsuccessful as a nocturnal predator. British scientists produced the first rudimentary airborne intercept (AI) radar for fighters by August 1940 and turned to the American lend-lease Douglas DB-I Boston attack bomber as a replacement for the Defiant. 91 The Boston was a twin-engined attack bomber with sufficient power to carry the weight of the airborne electronics, a pilot and the radar operator. Two R.A.F. squadrons, No. 85 and No. 93, were used in a bizarre night fighting concept called Pandora. 92 The Boston was supposed to find an incoming enemy formation by using the airborne intercept radar and then drop small aerial mines, which were attached to stabilizing parachutes by a two-thousand-foot-long strand of piano wire, in front of the enemy aircraft. In theory an enemy bomber would snag the piano wire and the little explosive would be snapped upward and into the enemy

\footnotetext{
${ }^{91} \mathrm{Bill}$ Gunston, ed., The Illustrated History of Fighters (New York:
Books, 1983), 31 . Exeter Books, 1983), 31 .

${ }^{92}$ Ibid. , 30 .
} 
aircraft to detonate upon contact. Pandora was a dismal failure, but it illustrated the desperate measures which the defenders were willing to take in order to stop the nightly raids by the Luftwaffe.

Another desperate concept was Turbinlite. The idea was to equip the lend-lease Boston, now renamed Havoc I, with a powerful, 2,700 million candlepower searchlight in the nose. The Havoc would fly in consort with a Hawker Mk. I Hurricane day fighter; when an enemy bomber was located by the Havoc's radar, the intended victim would be illuminated in the beam of the searchlight while the Hurricane shot it down. The Turbinlite flights shot down two enemy aircraft, one British Short Mk I. Sterling bomber and seventeen British Havocs. 93 A better method of defending against the German bombers was obviously needed.

The time required to develop an aircraft for a specialized role, such as a radar-equipped fighter for night combat, from the initial design concept through the prototype stage, the testing stage and finally into production could take several years. The British couldn't wait. In september 1940, a new R.A.F. twin-engined attack fighter, the Bristol Mk.IF Beaufighter, was introduced to combat. The Beaufighter could carry the weight of the

$$
{ }^{93} \text { Ibid., } 31 .
$$


British-developed AI radar set, the pilot, the radar operator and four $20 \mathrm{~mm}$ cannon mounted in the nose, along with six wing-mounted .303 caliber machine guns. When the Beaufighter was pressed into service, it became an immediate success by making its first intercept in November 1940.94 When elements of the United states Army Air Corps (8th Airforce) began to arrive in Britain, the obsolescent Havocs were returned to the Americans. The Americans redesignated the former lend-lease attack bomber as the P-70 Boston and installed British AI radar equipment along with six forwardfiring .50 caliber machine guns or four $20 \mathrm{~mm}$ cannon mounted in the nose. 95 The $\mathrm{P}-70$ became the mainstay night fighter of the Army Air Corps until 1944, when it was replaced by a fighter specifically designed by Northrup for night, radarcontrolled combat.

By the time the Guadalcanal struggle ended, two American fighters, the P-61 Black Widow and the F7F-2N Tigercat, which were specifically designed as night fighters, were already in the proto-type testing stages. The Northrup P-61 Black Widow, a large twin-engined aircraft, had first flown in May 1942. By October 1942, the

\footnotetext{
${ }^{94}$ Elke Weal, John Weal and Richard F. Barker, Combat Aircraft of world War Two (New York: MacMillan, 1977), i34.

${ }^{95}$ Gunston, The Illustrated History of Fighters, 31.
} 
P-61 was entering production. 96 The American Navy had asked Grumman Aircraft to produce a night fighter capable of operating off a carrier. Grumman presented the Tigercat, also a twin-engined design, in February 1943. However, the first F7F-2N proto-type would not fly untii December 1943, and production would not begin until April 1944, too late for the sleek fighter to be deployed to the fleet units in the Pacific. 97

In early 1942, the United States Navy established "Project Affirm" located on the Quonset Point Naval Air Station in Rhode Island. The principal thrust of this special project was to investigate the feasibility of using single-engined carrier fighters in the nocturnal combat role as a stop-gap measure until the Tigercat could be deployed.98 Two single-engine, single-seat fighters were in the proto-type testing stages at the time: The chanceVought F4U Corsair and the Grumman F6F Hellcat. Both were very large aircraft, compared to the fighters then in service, and each fighter could carry a large payload. The corsair could climb at a rate of 3,120 feet per minute and had a top speed of $446 \mathrm{mph}$, making it one of the

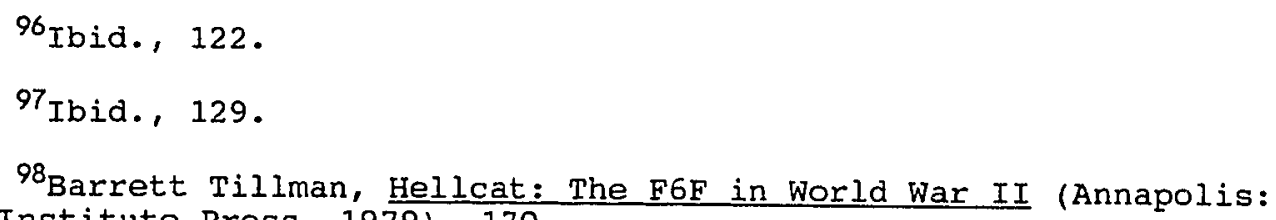


fastest fighters of the war. The Hellcat climbed at 3,100 feet per minute but its top speed of $360 \mathrm{mph}$ made the Grumman fighter's performance inferior to the corsair. However, the F4U had a penchant to bounce when making a carrier landing. This dictated the use of experienced pilots when operating the corsair off a carrier. The Navy elected to discard the Corsair in favor of the Hellcat to the delight of the United States Marine corps. The stepchild branch of the Navy was suddenly provided with the opportunity to enter combat in the South Pacific using the better performing corsair. 99

Not all of the powerful Chance-Vought fighters were surrendered to the Marines. The first naval night fighter squadron, $\mathrm{VF}(\mathrm{N})-75$, was equipped with the F4U-2N Corsair. The Corsair carried a British AIA radar set mounted in a special pod on the leading edge of the right wing. When the squadron was ready for deployment, it was split in half. VF(N) -75 was deployed to the Solomon Islands in September 1943. It flew night operations off the Munda airstrip on New Georgia. 100 The remaining elements of the special radarequipped squadron were used to establish another nightfighter squadron, $\operatorname{VF}(\mathrm{N})-101$, deployed in four plane

\footnotetext{
${ }^{99}$ Ibid., 170. 100 Barrett Tillman, Corsair: The F4U in World War II and Korea
(Annapolis: Naval Institute Press, 1979), 53.
} 
detachments to the fleet carriers. 101 The next two nightfighter squadrons for tine American Navy, VF(N)-76 and VF(N)77, both equipped with the F6F-3E Hellcat. The electronic version of the Hellcat carried an Army-Navy airborne pulse search radar (AN/APS4) weighing 180 pounds. This radar was mounted in a special pod on the right wing. The APS4 radar with an effective range of only four miles was primitive when compared to aerial radar of today. 102 In Europe the typical night fighters deployed by both Britain and Germany were twin-engined aircraft which carried a pilot and a radar operator. The Pacific squadrons equipped with new Hellcat and corsair night fighter variants, required the pilot to perform the tasks of both pilot and radar operator.

As American radar technology developed a newer set (AN/APS6) was installed in the F6F-3N Hellcat. The new set weighed 250 pounds, an increase of seventy pounds. This added weight was offset by an increase in effective range from four to five miles. The radar had a better cockpit display allowing the pilot/radar operator to ascertain his relationship to a bogey by using a two-dot "paint" on the cockpit radar scope. The first blip represented the bogey while a second "ghost" blip indicated the attitude of the

\footnotetext{
${ }^{101}$ Tillman, Hellcat, 170.

${ }^{102}$ Ibid. , 171.
} 
night fighter in relationship to its intended victim. If the night fighter was high, the ghost blip would be above the victim and conversely, if low, below the victim. 103 New night fighters were provided with red instrument lights to retain the pilot's night vision. A radar altimeter provided the pilot with a precise reading of his height above the surface. Later, the Pacific night fighters were equipped with APS-13 tail warning radar for detecting any enemy aircraft emitting radar search pulses. Although this was a critical addition to the European night fighters which fought enemy fighters equipped with radar, it wasn't really needed in the Pacific because the Japanese never developed an effective radar-equipped night fighter.

When $\operatorname{VF}(\mathrm{N})-75$ began combat operations in october 1943 off the Munda airstrip, the Japanese were flying their nocturnal raids on the American positions in single-bomber sorties. The limited range of the British AI radar made locating a solo bomber a nearly impossible task. This problem was solved by the end of october when the United States Marines established a ground control intercept (GCI) station, code named "Moon," on Vella LaVella. It took time for the inexperienced operators to hone their electronic skills. The first successful night fighter kill was not 
recordsa until 31 November 1943, when a radar-equipped Corsair expended 128 rounds of .50 caliber ammunition to "flame" a Japanese Betty. 104 Operational doctrine for VF(N)-75 was to rotate the nightly CAP, later known as the "BATCAP," to insure that one night fighter would be on station throughout the night. The operator of the GCI radar, once a bogey was targeted, would vector the night fighter into a position where the airborne radar could pick up enemy aircraft. The pilot would then use his radar to close with the enemy bomber until he could see it. A short burst from six .50 caliber machine guns fired at point-blank range was sufficient to shoot down the enemy aircraft. When the night fighter detachments were deployed aboard the carriers in the Pacific, detachment commanders who believed in the electronic night vision were appalled to discover the carriers did not want them! The explanation of this opposition to the night fighter detachments was the need for extended man hours. The deck crews of the carriers worked from dawn to dusk, about fifteen hours, launching and recovering aircraft. Night operations would require the deck crews to work throughout the night, a period generally reserved for relaxation. The captains of the fleet carriers also believed the radar-controlled anti-aircraft guns of the 
protecting cruisers and destroyers would be sufficient to handle any nocturnal intruder. A compromise was struck and the night fighters were allowed to perform in the role of "DUSKCAP" and "DAWNCAP" patrols over the task force.105 While night fighter pilots were being trained the war in the Pacific continued. United states forces landed at Lae and Salamaua on the large island of New Guinea on 3 September 1943. The Japanese attempted to disrupt the landing by using a force of two heavy cruisers, two light cruisers and six destroyers to attack an American force of four cruisers and eight destroyers. Radar-controlled gunfire allowed the weaker American force to sink the Japanese cruiser Sendai and a destroyer. The heavy cruiser Haguro sustained heavy damage during the action. On the American side, only the heavy cruiser Denver received hits. Radar was finally showing promise as a weapon to enhance surface combat.

The United States Navy initiated raids on the Japanese bastion on Truk, using carrier aircraft to hit the harbor installations on 5 November and 11 November 1943. On 20 November, Tarawa and Makin were assaulted. Kwajalein was softened by carrier strikes on 4 December. The Marshall Island airfields were hit by carrier strikes on 26 December

${ }^{105}$ Tillman, Hellcat, 172 . 
1943. The significance of these raids was an increase in the size of the task force from one or two carriers accompanied by three or four cruisers and six to nine destroyers, to a task force which included up to six attack carriers supported by six to seven light carriers and defended by six to eight modern battleships, six or more cruisers and thirty to forty destroyers.

When the new Essex-class carriers began to reach the Pacific Fleet in late 1943, their airgroups included the new TBM Avenger torpedo bomber, the SB2C Helldiver dive bomber and the F6F Hellcat fighter. A few of the Avengers had been stripped of all unnecessary weight and the torpedo crewman was removed to allow the installation of a British designed air-to-surface radar. The radar set was installed in the torpedoman's compartment and the antenna, which resembled a directional TV antenna, was mounted under the wing. The radar display was mounted in the cockpit for the pilot's use. 106 The radar-equipped Avengers would eventually perform a variety of roles: night intruder, night heckler, electronic counter-measure ferret and command ship for orchestrating large aerial operations. 107 Eventually, a few of the Helldivers would also be equipped with air-to-

\footnotetext{
${ }^{106} \mathrm{Tillman}$, Avenger, 59.

${ }^{107}$ Tillman, Hellcat, 175.
} 
surface radar. The Essex class carriers easily accommodated up to ninety-six aircraft, thirty-six fighters, thirty-six dive bombers and eighteen torpedo bombers with room to spare for the night fighter detachment composed of four to six radar-equipped Hellcats. File Essex-class carriers provided the strike aircraft, including the fighter escorts. The light carriers carried from forty to fifty aircraft and provided the CAP over the task force. The battleships, cruisers and destroyers provided a shield of radarcontrolled, anti-aircraft gun fire against any enemy bombers penetrating the CAP. In addition to their tasks in antisubmarine patrol and forming the outer anti-aircraft defensive ring, the destroyers stationed along the peripheral fringes of the task force would establish an early warning radar picket line to give fighter director officers aboard the light carriers an additional cushion of time to vector and scramble additional air defenses. The escort carriers (CVE) served as reserve transports for aircraft and pilots to replace the losses incurred in battle by the larger carriers. Once the amphibious assault landings were initiated, the CVE's provided air support and a defensive CAP for the landing operation.

By early 1944, the PPI radar display scope was deployed to the Pacific fleet. The new display provided the radar operator with a circular screen, upon which concentric rings 
had been painted. The center of the display represented the radar operator's ship and the radar operator now had a far better perspective as to the position of his ship relative to other contacts painted by his radar returns. 108

Meanwhile, United States Marine corps air units were shedding their reputation as the "step-children" of naval aviation because the Corsair fighter allowed Marine pilots to record an impressive number of kills. In January 1944, the first ilarine night fighter squadron, $\operatorname{VMF}(\mathrm{N})-532$, began to operate the F4U-2N Corsair off the airstrip on Tarawa in the Gilbert Islands. A month later a detachment from $\operatorname{VMF}(\mathrm{N})-532$ was moved to the island of Roi. At 2400 hours on the night of 13-14 April 1944 a Marine Corsair intercepted a Japanese Betty. While shooting it down the corsair was fatally hit by $20 \mathrm{~mm}$ defensive fire from the Betty's tail gunner. A few minutes later his companions attempted to intercept what they thought were additional bombers. To their surprise the Marine pilots discovered they were intercepting strips of thin aluminum chaff. The chaff, also called window, was being tossed out of the Japanese bombers to confuse the radar of the night fighters. Apparently, the Japanese had been provided with the counter-defensive radar

${ }^{108}$ Clay Blair Jr., Silent Victory: The U.S. Submarine War Against Japan, Vol. 1. (Philadelphia: J.B. Lippincott Company, 1975), 420. 
technology by their Nazi allies. 109

The United states Navy wasn't the only service to receive new equipment. In May 1944, the 6th Night fighter Squadron of the United States Army Air Force received the first delivery of the highly secret P-61 Black Widow as a replacement for their aging Bostons. Once the squadron had completed its familiarization phase with the new night fighter, it was scheduled for redeployment to saipan. But first the island had to be captured. The next squadron to receive the Black Widow was the 419 th located on Guadalcanal. 110 The P-61 was specifically designed for night combat and the key to the potential success of the Northrup-designed fighter was a sophisticated and highly classified electronic system with an SCR-720 nose-mounted antenna. The SCR-720 radar had a phenomenal range of approximately one hundred miles and incorporated an IFF interrogator-responder. 111 Four $20 \mathrm{~mm}$ cannon were side mounted in special bulges along the sides of the fuselage. In addition to the $20 \mathrm{~mm}$ cannon a remote-controlled turret was mounted along the dorsal spine of the aircraft. The P61 could achieve a maximum speed of $380 \mathrm{mph}$, a little less

${ }^{109}$ Tillman, Corsair, 77.

${ }^{110}$ Larry Davis and Dave Menard, P-61 Black Widow in Action: Aircraft Number 106 (Carollton, TX: Squadron/Signal Publications, Inc., 1990), 10.

${ }^{111}$ Ibid., 5 . 
than the naval Hellcat and Corsair, but the trade off in speed was a combat radius of fifteen hundred miles. The Black widow received its name from its glistening black camouflage scheme. It had been discovered by accident that a gloss black paint reflected light better than a flat black, making the large fighter more difficult to see. In its gleaming color scheme the large fighter resembled an enormous, deadly black widow spider. 112 The Black Widow would be a deadly adversary to the Japanese as both a night fighter and a night intruder. When the $\mathrm{P}-61$ was not prowling the skies looking for enemy aircraft, it carried two five-hundred-pound bombs and, when they became available, eight of the new five-inch, High Velocity Aerial Rockets (HVAR). 
Chapter 8

Philippine Sea

A new heavy bomber, the B-29 Super Fortress, was first introduced in India and then China. The new bomber could carry a tremendous bomb load of twenty thousand pounds and had a combat radius of 2,800 miles. The service ceiling of the B-29 was 31,800 feet and the bomber could attain a maximum speed of $358 \mathrm{mph}$. Therefore, the B-29 could fly well above most Japanese interceptors of the period and outrun all but the newest Japanese fighters. For defense the B-29 had four remote-controlled turrets, each with two .50 caliber machine guns. By flying in a standard box formation the defensive firepower of a squadron of six B-29 bombers made them virtually impregnable. One more innovation had been added to the B-29 bomber. The bomb sight was now linked to radar, giving the bombers far more accuracy than ever before and the ability to navigate and bomb through overcast conditions which had previously prevented conventional bombers from hitting their target. The B-29, if stationed in the Marianas, could effectively strike at the Japanese home islands; but first the islands had to be captured and secured. What the 
Americans didn't know was that the Japanese had become obsessed with the thought of destroying the United states Navy in a final, show-down battle. On 6 May 1944, Admiral Matome Ugaki argued for the strategy of taking on the American Navy in a series of small, decisive engagements, but his superiors over-ruled him. ${ }^{113}$ The Japanese readied the mobile force for "Operation A-Go," the show-down battle which they had decided would take place in the Bismarck sea. In his war diary, Admiral Ugaki revealed on 12 May 1944 that the Japanese were cognizant of American radar and its effectiveness in naval combat. Admiral Ugaki also expressed his frustration because the Japanese Navy had been stripped of its advantage in nocturnal surface combat by the American radar. 114 Now the Japanese were about to experience an entirely new development in the arena of night combat.

Task Force 58, under the command of Admiral Raymond $A$. Spruance, moved into Japanese controlled waters off the Marianas on 12 June 1944 to initiate "Operation Forager." TF-58 was comprised of several separate elements, each a task force in its own right. TF-58.1 included the carriers Hornet (new), Yorktown (new), Belleau Wood and Bataan. TF58.2 included the carriers Bunker Hill, Wasp (new), Monterey

\footnotetext{
${ }^{113}$ Ugaki, Fading Victory, 368.

${ }^{114}$ Ibid., 370.
} 
and Cabot. TF-58.3 included the carriers Enterprise,

Lexington (new), San Jacinto and Princeton. TF-58.7 included seven modern battleships to provide surface defense and a massive wall of radar-controlled anti-aircraft gunfire. Not only were the five-inch secondary batteries of the battleships controlled by radar but the $40 \mathrm{~mm}$ close in antiaircraft guns were now linked to the radar fire control system. One more innovation had been added to the American arsenal. The five-inch anti-aircraft projectiles were now using a miniature radar system installed in the nose of the shell. This tiny radar gave the projectile the ability to sense when it was within lethal proximity to a potential target, making a direct hit no longer essential to bring an enemy aircraft down. An exploding five-inch anti-aircraft projectile would provide sufficient shrapnel to cause considerable damage to any airplane, usually enough to bring it down. The advent of this proximity shell would increase the effectiveness of the anti-aircraft defensive gunfire by a considerable degree. ${ }^{115}$

Each carrier in the various task forces carried early warning radar, as did the picket destroyers. Aboard the carriers were the night fighter detachments and a few radarequipped Avengers and Helldivers. The Battle of the

\footnotetext{
${ }^{115}$ Adrian Stewart, The Battle of Leyte Gulf (New York: Charles Scribner's Sons, 1979), 21 .
} 
Philippine sea would allow the radar-equipped aircraft to prove their real worth in combat, but the reluctance of the carrier commanders to engage in nocturnal operations would continue to be a formidable obstacle.

Realizing that the Americans intended to take the Marianas, the Japanese Navy modified its plans to engage the United states Navy in a final decisive battle. The Mariana Islands of Guam, Tinian, Rota and Saipan were major bastions, having formidable defenses against invasion and numerous airfields from which the Japanese air flotillas could sortie. The modified plan was to use the island airfields as unsinkable carriers. After all, the Americans had effectively used the same concept on Guadalcanal. Japanese bombers would be shuttled from Formosa to Guam, striking the American task force enroute and then use the island airfields as bases from which the American armada could be attacked again and again. Admiral Ugaki stated in his 15 June 1944 war diary entry: "land based aircraft must sink at least one third of the enemy carriers before the decisive phase of the battle takes place."116 The plan had merit. But the Japanese didn't understand the effectiveness of the radar technology which would be pitted against them. For the first time in a major battle, all of the radar

${ }^{116}$ Ugaki, Fading Victory, 402 
technology of the American forces in the Pacific would be brought to bear against the Japanese.

Although the Battle of the Philippine sea was a classic carrier battle, other combatants shared the limelight. The most dangerous threat to a submarine is an airplane armed with depth charges or bombs. A submarine which surfaced during daylight hours invited disaster, for there was no such thing as a friendly airplane. The United states Submarine service had toyed with radar as early as 13 December 1941, when the submarine plunger was fitted with a primitive SD radar to detect aircraft. The problem with the SD radar was a limited range of six miles and the inability to provide a bearing for an approaching bogey. Plunger, while submerged at periscope depth, would poke the radar above the surface of the water on a special radar mast. If the radar indicated the area surrounding the submarine was clear of aircraft, Plunger would surface. Commander David C. White, skipper of the Plunger, was a cautious individual. The radar test was a failure, for commander white preferred to rely upon human lookouts rather than his new electronic warning device. 117

In August 1942 , the submarine Haddock was fitted with newer SJ radar, which was capable of performing both aerial

$117_{\text {Blair, silent Victory, } 91 .}$ 
and surface search roles. The sJ radar could provide an exact bearing and range to a surface vessel at night and during inclement weather conditions of rain, fog or snow. 118 During radar trials in the China sea, on 12 August 1942, Haddock detected and sank two Japanese ships during the night. The contact and subsequent intercept of the submarine's two victims was credited to the new radar. Two weeks later, on 26 August 1942, Commander Arthur H. Taylor, captain of the Haddock, successfully completed an "end run" by using his radar to maintain contact with the victim. With accurate position reports from his electronic eye he set up his attack and waited. Teishun Maru, 2,250 tons, was dispatched with two torpedo hits. The result of the Haddock trial was so successful that all submarines in the United States Navy were fitted with the new electronic sensing device as rapidly as possible. At the same time specialists in radar operation and repair were added to the submarine crew rosters. 119

\section{Plunger, when refitted with SJ radar, was assigned a} war patrol off the island of Truk. In November 1942, while running on the surface at night, the submarine's radar picked up a surface contact. Commander white thought the

$$
\begin{aligned}
& { }^{118} \text { Ibid., } 296 . \\
& { }^{119} \text { Ibid., } 297 .
\end{aligned}
$$


contact, because of its size, was an island, but his executive officer, David H. McClintock, thought otherwise. He made a snap decision and fired a spread of four torpedoes at the unseen contact, a Natori class cruiser. Commander White ordered a crash dive and hit the bottom, breaking off his sonar heads, forcing an end to the patrol. After an investigation into the incident, Admiral W. F. Halsey urged his submarine commanders to trust their SJ radar and to remain on the surface while making repeated night attacks using the radar. ${ }^{120}$ By August 1943, the submarine Snook had been provided with the new PPI display.121 As additional boats were equipped with it the effectiveness of American submarines in nocturnal surface torpedo attacks increased.

The Battle of the Philippine sea began on 11 and 12 June 1944, with aerial sorties from eight attack carriers against the airfields on Saipan, Tinian, Rota and Guam. The purpose of the air raids was to crater the runways and destroy aircraft on the ground in preparation for the invasion of Saipan. Night fighters, acting as night intruder fighter bombers with two five-hundred-pound bombs attached to their wings, continued the process of cratering

\footnotetext{
${ }^{120}$ Ibid., 305.

121 Ibid., 420.
} 
the runways after the daylight raids were completed. Once the bombs were expended, the night fighters turned to strafing aircraft on the ground. The few Japanese aircraft which attempted to take off were quickly shot down. Following the air attacks, the seven new battleships of TF58.7 bombarded the defenses of Saipan and Tinian. The bombardment did little damage due to the inexperience of the battleship crews in bombardment procedures, but this problem was rectified on 14 June 1944 when eight of the older battleships, whose crews were more experienced in naval bombardment, continued the softening up process. On Saipan, the Japanese garrison of 31,500 men held on, waiting for the Japanese mobile fleet to arrive.

Aboard a submarine the visual range of a human lookout was limited. Even with light-enhancing binoculars, detection of a Japanese surface ship was difficult. Radar gave the submarine the advantage of electronically scanning to the horizon and picking up objects which were otherwise invisible. Setting up for a torpedo attack against a fastmoving warship was almost impossible unless the warship was approaching the submarine. The end-run tactic, which was possible against a slow-moving cargo vessel, was not feasible against the faster warships as the American submarine of the period could only achieve nineteen knots when running surfaced on diesel engines. The typical 
Japanese warship cruised at a speed of twenty-five to thirty knots. Therefore, the key advantage of the radar-equipped submarine was its ability to detect enemy surface units and to radio a "flash" contact report, giving the course, speed and approximate number of enemy ships. Vice Admiral Raymond A. Spruance, in command of TF-58, knew that when the invasion of Saipan commenced, the Japanese would be forced to intervene. He prudently placed American submarines as advance scouts to watch the major straits through which the Japanese would be forced to sail to enter the Philippine Sea. The American admiral elected to fight a defensive battle by sending aloft swarms of Hellcat fighters and by relying upon radar-controlled anti-aircraft fire from the ships of the surface fleet. Radar would give him the edge he needed. His action was quickly justified.

The invasion of Saipan commenced on 15 June 1944, with 550 ships taking part in the amphibious operation, including eight escort carriers with a total of 170 aircraft. When the Japanese received word that Saipan was being attacked, the order was given to the Mobile Force to relieve the island and to annihilate the American Pacific Fleet. At 1800 hours on 15 June 1944, the radar from the light carrier San Jacinto picked up enemy aircraft approaching the task force at a distance of fifty-two miles. The CAP was immediately vectored to intercept the incoming bogeys and 
the first aerial skj.rmish ensued. Ironically, as the Japanese planes were being shot down by the American Hellcats, the Japanese pilots wrongly reported they had sunk four American carriers and six other vessels. It isn't known if the Japanese admirals believed the report or not, but the "A-Go" operation continued.122 At 1845 hours, Enterprise launched two F4U-2N Corsair night fighters to provide a BATCAP over the task force.

The first submarine "flash" warning came at 0900 hours on 16 June 1944 from Redfin, which reported the main Japanese fleet was departing Tawi Tawi anchorage. The next report came from Flying Fish, indicating that enemy units were moving through the San Bernardino strait. At 1845 hours, radar aboard seahorse detected enemy warships moving through Surigao strait. The course and speed was calculated, as well as a fairly accurate ship count. What the American submarine could not detect were the ships over the horizon.

At 1905 hours, 16 June 1944, Enterprise detected enemy aircraft at five miles. Eight Francis torpedo bombers, escorted by five zero fighters, had penetrated within striking distance of TF-58.3 The BATCAP night fighters sent a "flash" warning as they made their attacks, along with a 
positive identification of the enemy bombers. As the enemy torpedo bombers began their runs against the American ships, they flew into a wall of radar-controlled anti-aircraft fire from the battleships and cruisers. The proximity shells of the five-inch batteries took their toll of the enemy aircraft, as did the radar-controlled gunfire of the $40 \mathrm{~mm}$ batteries when the enemy flew into closer range. All eight of the enemy torpedo bombers were shot down, along with one zero. ${ }^{123}$ At 2300 hours the submarine Cavalla picked up two Japanese destroyers, accompanied by two oilers on its radar and sent a "flash" report.

While the United states Marines were struggling to gain control of Saipan, the Navy established a seaplane base on the island from which they could operate a squadron of airto-surface radar-equipped Martin PBM Mariner patrol bombers. Like their PBY sisters, the large flying boats could remain aloft from dusk to dawn, keeping watch with radar over the horizon for any approaching surface threat. ${ }^{124}$ Admiral Spruance knew the Japanese were coming, and he didn't want to be surprised.

The following day, 17 June 1944, Cavalla's radar picked up seven large blips at twenty thousand yards. The American

${ }^{123}$ William T. Y'Blood, Red sun setting: The Battle of the Philippine Sea (Annapolis: Naval Institute Press, 1981), 69-70.

${ }^{124}$ Ibid. , 71. 
submarine had detected part of the Japanese mobile fleet on its radar, fifteen ships moving due east at nineteen knots. At 1735 hours, TF-58.2 picked up thirty aircraft at thirty miles on radar. At that moment, there was no defensive CAP over the task force. Seventeen Judy and two Francis torpedo bombers were approaching with thirty-one zero fighters. What the Americans didn't know was that each of the fighters carried a five-hundred-pound bomb. The only defense for the task force was radar-controlled anti-aircraft fire. The attack resulted in numerous enemy aircraft being shot down, while only the escort carrier Fanshaw Bay was hit by a bomb. Vice Admiral Jinsaburo ozawa had planned to shuttle bombers from Formosa (Taiwan) to Guam and then use the island airfields as bases from which he could operate his aircraft. His plan was to catch the American task force in a sandwich between his island air power and his carrier air power. But the island airfields had been rendered inoperable by the airstrikes from the American carriers. For some, unknown, reason, Vice Admiral Kakuji Kakuta, commander of the island defenses, had not informed ozawa of this fact. As Admiral Ozawa's Mobile Force approached the islands, he launched his initial carrier strike. At 0910 hours, shortly after the last aircraft had departed from the deck of the carrier Taiho, a torpedo spread was fired from the submarine Albacore. One of the torpedoes hit Taiho. 
The Japanese carrier would explode and sink six hours later. Within the TF-58.7 battleship rapid reaction force the new battleship Alabama picked up incoming bogeys on radar at approximately 140 miles. At 0957 hours, 19 June 1944, the warning was flashed to the task force and radars aboard the various carriers in the task force confirmed the contact. These aircraft had taken off from the airfields on Guam, which had not been entirely neutralized, and rapidly approached to within 121 miles of the task force at an altitude of twenty thousand feet. The problem for the carrier fighter director officers was to commit the right number of fighters to deal with a threat while retaining enough fighters in reserve to meet any additional threat. A CAP was vectored to intercept the approaching bogeys, while a back-up CAP was established between the attacking fighters and the task force. A problem which still plagued the fighter director officers was that of communication, now due to the sheer volume of radio traffic from the numerous American fighters in the air. The few Japanese aircraft which managed to break through the fighter screens were effectively dealt with by the task force's radar-controlled anti-aircraft fire. However, reports from the CAP which had engaged the enemy aircraft confirmed that the escort zeros 
were also carrying five-hundred-pound bombs. 125

The men aboard the American task force ships were not

allowed much time to rest. At 1130 hours a new threat appeared on Lexington's radar, bearing 270 degrees at 160 miles: A strike group from Admiral Ozawa's carriers, the Shokaku, Zuikaku and Taiho. Hellcats orbiting at 25,000 feet attacked a force of approximately one hundred Jill and Judy bombers. Only twenty enemy aircraft breached the aerial screen. Again, the radar-controlled anti-aircraft fire knocked down those which managed to break through the aerial screen. The destroyer stockton, which was on picket duty, claimed three enemy aircraft destroyed and two damaged. While the aerial battle was being fought over that American task force, the submarine Cavalla attacked the carrier shokaku. At 1152 hours three torpedoes hit the veteran carrier and by 1500 hours shokaku rolled over and sank.

At 1215 hours the radar screens aboard the American task force ships were clear. The respite lasted ten minutes. Then a third air strike was detected. Again, the fighters on station were vectored to intercept the approaching threat. The threat turned out to be a phantom, for heavy cloud cover in the area was beginning to interfere

\footnotetext{
${ }^{125}$ Ibid., 118.
} 
with the radar readings. The clouds showed up as a large blip, just like a large formation of enemy aircraft. At 1330 hours radar from the light carrier Monterey picked up incoming bogeys at 134 miles. Since the fighter director officer aboard Monterey was the nearest to the threat, he was given control over the ensuing battle as procedures dictated. However, the aerial battie also involved fighters from the carrier Wasp. Due to communication difficulties aboard Monterey her fighter director officer relinquished his command to the fighter director officer aboard the Wasp. 126 Once more, the fighters prevented the majority of the enemy aircraft from reaching the task force. The few which did break through were quickly dealt with by the radar-controlled anti-aircraft fire from the American ships.

A fourth group of raiders, a large formation of Japanese bombers and fighters, was led by a Jill torpedo bomber equipped with a navigational form of radar. ${ }^{127}$ The Japanese pilot of the radar-equipped Jill had no means of detecting American radar, and while enroute to the airstrips on Guam the formation was picked up by the fighter director officer aboard Hornet. The fighter director officer vectored fighters from both Hornet and cowpens to make the

$$
\begin{aligned}
& { }^{126} \text { Ibid., } 139 . \\
& { }^{127} \text { Ibid., } 154 .
\end{aligned}
$$


intercept. He had not anticipated the number of aircraft which would become involved in his little skirmish. Forty Japanese bombers were attacked by fifty-eight fighters from the carriers Hornet, Cowpens, Essex, Enterprise, San Jacinto and Princeton. As the melee continued over the cratered runways on Guam, Japanese aircraft became pyres of flame and smoke as they fell from the sky. The outcome was a euphoric victory for the American Hellcat pilots.

At 1740 hours radar aboard the Bunker Hill picked up a bogey at 109 miles. Twelve Hellcats were vectored to intercept. Two Betty bombers, outnumbered six to one, were quickly dispatched. At 1827 hours radar aboard the Essex picked up bogeys closing on Guam. Again, Hellcats were vectored to intercept. As the Hellcats closed on their victim, they were "bounced" by seventeen zero fighters. This time the Japanese faced a fighter superior to the vaunted Zero in speed, climb and firepower. The American fighters were also being flown by pilots who were better trained in combat tactics than their opponents. The outcome was a foregone conclusion.

The day of 19 June 1944 ended after twelve continuous hours of aerial combat. The Japanese lost 294 aircraft, 244 from Admiral Ozawa's carriers and fifty from Admiral Kakuta's land-based forces. Radar-controlled anti-aircraft fire destroyed nineteen enemy aircraft. In addition, the 
Japanese lost two attack carriers, Shokaku and Taiho, along with twenty-two aircraft which were aboard at the time. American losses amounted to twenty-two fighters. ${ }^{128}$ The "Great Marianas Turkey Shoot," as the Battle of the Philippine sea is often called, was a total success due to the carrier fighter director officers who, with radar technology, orchestrated the air battle. The fact that only a few ships in the massive American armada were hit at all can be attributed to the effectiveness of the proximity shell and radar-controlled gunfire. The Battle of the Philippine Sea shattered Japan's naval air power. The Japanese could replace their losses in aircraft, but it would take time to train pilots, and Japan no longer had the luxury of time.

Although the Americans were unaware of any organized kamikaze effort, Admiral Ugaki revealed in his war diary entry of 19 June 1944 that an ad-hoc group of fighterbombers had sortied out to deliberately crash their zeros onto the decks of American carriers. Admiral Ugaki wrote:

I placed great expectations on the results of suicide attacks by fighter-bomber squadrons on the 19th, but powerful fighters counter attacked them at a point twenty miles short of the enemy and only ten of thein seemed to succeed in crashing on the enemy. ${ }^{129}$

\footnotetext{
${ }^{128}$ Ibid., 140.

${ }^{129}$ Ugaki, Fading Victory, 421.
} 
Actually, none of the ad-hoc suicide fighter-bombers made it to the American task force, and the men of the United states Navy were unaware of the intent of this group of fanatical pilots.

The follow-up to the Battle of the Philippine sea came on 21 June 1944, when the scattered elements of the Japanese Force $C$ were discovered by a radar-equipped Mariner. The Mariner called for help and a strike group from Wasp was vectored to the attack while the Mariner's pilot acted as an interim fighter director officer. However, in the ensuing battle eighteen American aircraft were destroyed. This was partly due to early warning radar aboard some of the larger Japanese ships. The Japanese carriers were alerted in time to launch additional fighters to defend the ships. The carrier zuikaku was damaged, along with the Chiyoda. The carrier Hiyo, was sunk while a total of sixty-five Japanese fighters were lost in the defense of the ships. As the American aircraft returned, they were caught by the blackness of the Pacific night. Radar-equipped night fighters and Avengers were sent out to find returning aircraft in the darkness. The attempt was successful, and the radar-equipped aircraft acted as guides to bring the stragglers back to the fleet, where Vice Admiral Marc A. Mitscher had ordered search lights turned on, a dangerous precedent in contested waters. 
On 21 June 1944, before the island of Saipan had been completely secured, the Army's 6th Night fighter squadron arrived and began to operate P-61 Black widow night fighters from Isley Field, the major "captured" airstrip on the island. The P-61 would primarily operate as a "free-lance" night stalker, flying without the benefit of any GCI radar control. Nine days after landing on Saipan, the first kill for the P-61 Black Widow was recorded when it "flamed" a Japanese Betty bomber over the sea approaches to the island. 130

Even though night fighters had shown their potential auring the Battle of the Philippine Sea, carrier skippers were still reluctant to use them at night. Prior to the Battle of the Philippine Sea, the United States Navy discovered the F6F Hellcat could carry two five-hundredpound bombs. With six .50 caliber machine guns the stout fighter had become a deadly fighter-bomber, capable of delivering a payload and then performing the role of a fighter. Therefore, the night fighters, which were looked upon as "supercargo" with radar, were pressed into service as night intruder aircraft. This mission became an operational standard for the nocturnal fighter turned fighter-bomber. On 4 July 1944, two Hellcat intruder-

${ }^{130}$ Davis and Menard, Black Widow, 10. 
fighter-bombers from VF(N)-76, assigned to the Hornet, were sent to attack reported enemy shipping in the harbor of Chichi Jima in the Bonins. The pilots of the nocturnal strike did not expect any Japanese fighter opposition. At 0030 hours, as the Hellcats completed an attack on a Japanese destroyer, they were attacked by nine or ten Rufes, the float version of the zero fighter. The ensuing dog fight lasted thirty minuces and resulted in eight of the attackers being shot down. ${ }^{131}$ That the American night fighters were able to shoot down more than one or two of the Rufe fighters was a remarkable feat, for the radar-equipped Hellcats were operating as "free-lance-rovers," using their limited range radar without the benefit of GCI radar guidance. Of the twenty-five enemy aircraft claimed by VF(N) -76 , these were the only night kills recorded by the detachment in a period lasting from April to september 1944. The carrier skippers were not impressed.

The concept of a "pure" night operations air group was implemented with the formation of $V F(N)-79$, flying the F6F$5 \mathrm{~N}$ Hellcat, and $\mathrm{VT}(\mathrm{N})-41$, flying the TBM-1D Avenger torpedo bomber, in January 1944. The idea was to use an aircraft carrier exclusively dedicated to night operations. The light carrier Independence was selected as the operational 
test platform for the all-night operations concept.

Independence deployed to the fleet and engaged in its first test of nocturnal combat operations on 29 August 1944. The operational test of the all-night concept was a disaster. The radar sets had been removed from most of the Hellcats, for fear the Japanese might capture one of the fjghters and discover the secret of radar. The attitude of the task force carrier skippers to refrain from conducting night operations was reinforced as they thought it was no longer necessary with the Independence providing aircraft for BATCAP and night intruder sorties. The result was that the night fighter pilots of the larger carriers lost their acquired skills through inactivity, and other highly trained night fighter pilots were simply absorbed into existing daylight operating squadrons.

In 1944 the Japanese began to conduct tests with radar to control the large caliber guns aboard their battleships. On 4 August, yamato conducted the initial radar-fire-control tests, but the results were inconclusive. ${ }^{132}$ Four days later, Musashi conducted more tests. Again, they were disappointing. When compared to the American radar, Japanese radar was still in the primitive stages. Admiral Ugaki recorded his thoughts regarding radar into his war

${ }^{132}$ Ugaki, Fading Victory, 439. 
diary on 9 August 1944:

How to use radar is taking shape, but much is still desired in its capacity and accuracy... to depend entirely and blindly on it should be limited to cases where no other means are available. I wish we [the Japanese] could make some improvement in this useful weapon in which we are so far behind. 133

Obviously, the Admiral saw the potential of radar, but like his American counterparts during the early war years, he was reluctant to trust the electronic phenomenon. Admiral Ugaki concluded on 20 August 1944 that radar fire control for naval guns would never be successful. 134

\footnotetext{
133 Ibid., 439.

${ }^{134}$ Ibid. , 442 .
} 
Chapter 9

Leyte Gulf

The American naval planners, including the Chief of Naval Operations Admiral Ernest J. King, wanted to by-pass the Philippines and attack Formosa (Taiwan). However, General Douglas MacArthur insisted on an invasion of the Philippines, arguing that if America did not invade the island archipelago, then no ally of the United states would ever trust the American nation again. MacArthur got his way •

In preparation for the invasion of the Philippines the Americans began to attack the Japanese airfields there. On 26 August 1944 the Japanese lost 173 planes in aerial combat and a total of 355 aircraft on the ground. 135 After the Japanese replaced their losses, a second carrier strike was conducted on 22 September 1944 in which 455 Japanese aircraft were destroyed on the ground and in aerial combat. 136 At sea, attacks against Japanese shipping continued without abatement. On 22 september 1944 the

\footnotetext{
${ }^{135}$ Ibid. , 454.

136Ibid., 461.
} 
Japanese lost fourteen destroyers and fourteen transports in a surface action. Radar was giving the Americans a decided edge in the surface actions, and the Japanese admirals were becoming frantic. Admiral Ugaki indicated his frustration in his 29 september 1944 entry into his war diary:

Unless something is done, our losses will add up, together with those of aircraft. We must destroy the enemy [the American Navy] first."137

The Japanese had to force a final show-down battle. If the Americans established a foothold in the Philippines, the Japanese would be cut off from their source of oil and other raw materials needed to continue the war.

Operation "Sho-1" was put into motion by the Japanese. Vice Admiral Takeo Kurita, in command of the First strike Force, placed his battleships and cruisers at Lingga Roads near singapore in order to be near the Japanese fuel supply. Vice Admiral Kiyohide Shima, in command of the second strike Force, stationed his destroyers and heavy cruisers in the Ryukyus. Vice Admiral Ozawa, commanding the Main Body, kept his carriers in the Inland sea while awaiting aircraft and pilots to replace those lost during the Battle of the Philippine Sea. Vice Admiral Gamichi Mikawa, commanding the Southwest Area Force of land based naval air units in the

${ }^{137}$ Ibid., 463. 
Philippines, began to build up his aerial strength. 138 The Japanese Army, which operated independently from the Navy, was not about to offer its aerial assets in a cooperative effort as this would place the Army pilots under the direct command of the Japanese Navy.

Because of the massive losses of aircraft, incurred during the Battle of the Philippine sea and subsequent actions with the American carrier aircraft, the naval air force had to be rebuilt from scratch. Aircraft could be replaced but a shortage in aviation gasoline exacerbated the problems in training pilots for carrier operations. The pilot trainees were given only the most rudimentary skills in flying with instruction in how to take off, land and fly in formation. In subsequent aerial attacks upon the American forces this lack of training for the Japanese pilots would be disastrous.

Japanese strategy for the "Sho-1" operation was to allow the Americans to establish a beachhead in the Philippines. Then the Japanese would attack and destroy the beachhead, supply dumps and the transports and cargo vessels which were needed to support the American forces ashore. If the American battle fleet intervened, then the powerful battleship force of Vice Admiral Takeo Kurita, which

${ }^{138}$ Stewart, Leyte Gulf, 20. 
included the super battleships Yamato and Musashi, would take care of the problem. ${ }^{139}$ In spite of their reluctance to accept radar, the Japanese had continued to train with the electronic weapon, modifying their procedures for night attack by using radar and flares to assist in obtaining more accurate gunfire. Radar was also seen by the Japanese as a potential aid in anti-aircraft defensive fire. ${ }^{140}$ Fortunately for the American forces, Japanese radar was too primitive to be of any advantage and there were just too few of the precious sets for them to be installed on every ship. Land-based aircraft would open the operation by attacking the American carriers to neutralizing them. Once the American carriers were eliminated from the battle, landbased aircraft would support the First Attack Force in annihilating the American amphibious forces. Vice Admiral Ozawa's Main Body was to act as a decoy, luring the American Battle Fleet from the beachhead defenses to the northeast. As shocking as it might appear, the Japanese saw their few remaining carriers as expendable assets. ${ }^{141}$

The American attack carriers of the Pacific Fleet had removed the radar from most of their night fighter aircraft.

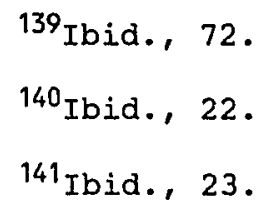


The few operational aircraft with radar were allowed to conduct nightly strikes upon the airfields on Formosa During these nightly forays night fighters began to demonstrate their effectiveness. The nocturnal predators of VF(N)-41 claimed twelve kills, ten of which were during dark or semi-dark conditions. It was also discovered, perhaps to the surprise of the carrier captains, that the radarequipped fighters could operate during periods of inclement weather when most other aircraft were grounded. Several kills during inclement weather conditions proved the value of the radar-equipped night fighter. 142 Perhaps the radar-equipped fighters could be of some service after all. Admiral William F. Halsey, commander of the American 3rd Fleet, did not intend to allow the Japanese to build up massive aerial forces with which to defend the Philippines. He initiated a series of carrier raids upon the Japanese staging airfields. On 10 October 1944 aircraft from Halsey's 3rd Fleet hit okinawa. On 11 october 1944 carrier strikes devastated air bases on Luzon. Halsey struck again at the air bases on Formosa on 12 october 1944. The Japanese shifted to night attacks, using massive formations of land-based Betty bombers armed with torpedoes. Fortunately, the light carrier Independence, with its radar-

\footnotetext{
${ }^{142}$ Tillman, Hellcat, 176.
} 
equipped night fighters, was operating with the fleet. During the night of 12 October 1944 the Japanese lost fortytwo bombers to the night fighters of the United States Navy. Another American carrier strike was undertaken on 13 october 1944. The Japanese countered with a massive one-hundredplane night attack on 13-14 October 1944. This time, there were too many enemy aircraft for the night fighters to deal with effectively. Several of the Japanese bombers broke through the BATCAP defense and torpedoed the heavy cruisers, Houston and Canberra. However, only twenty-five of the Japanese bombers returned to their bases, and none of the American carriers were hit. ${ }^{143}$ At this point in the preliminary skirmishing, Admiral Halsey saw an opportunity to lure the Japanese into a trap, and he allowed the two damaged cruisers to limp away with minimal escort. Admiral Soemu Toyoda, Commander in Chief of the combined Fleet, took the bait and ordered the 2nd strike Force to attack the crippled cruisers. A few of his more experienced pilots saw the danger and warned Toyoda, but he was determined to achieve a victory. The aircraft were flown by the "rookie" pilots who had only rudimentary instruction in take-off, landing and formation flying. None of these young pilots had any training in aerial combat. The strike, which took

\footnotetext{
${ }^{143}$ Ugaki, Fading Victory, 470.
} 
place during the night of 14-15 October 1944, resulted in the annihilation of the entire air group.

Enterprise, the veteran of numerous carrier battles, arrived to relieve Independence. Enterprise was configured as a night operations attack carrier and carried thirty-four F6F-2N Hellcats and twenty-one radar-equipped Avengers. New procedures had also been established for controlling the night fighters. Because of the limited range of the AN/APS6 radar, the CXAM radar aboard Enterprise would perform in the role of a floating GCI station. With the guidance from the GCI operator a number of the night fighter pilots were logging impressive scores. Additional carriers, as they reached the fleet, brought more night fighter detachments. This time the captains had specific orders to operate the radar-equipped aircraft as night fighters. 144 During the October air strikes more than five hundred Japanese aircraft were destroyed in the air and on the ground in both day and night operations.

One of the problems which plagued the Japanese plarners was the gross inaccuracy of their combat reports. During the battle of the Philippine sea Japanese bomber pilots had reported sinking least four American aircraft carriers and the damaging six other major warships. When American

${ }^{144}$ Tillman, Hellcat, 180. 
carriers mounted air strikes against the airfields on Formosa, the Japanese defenders claimed the destruction of eleven of the hated "Yankee" carriers. Ugaki mused: "if the U.S. carriers had been destroyed, then why were the Americans still conducting air strikes?"145

For the Japanese samurai, who adhered to the bushido code of conduct, defeat was an unacceptable loss of face, dishonoring the samurai's ancestors, his family, his emperor and his nation. It was better to die than to suffer defeat. The solution was to turn defeat into victory. The fantastic reports of Japanese success continued to influence the Japanese admirals. Another, more ominous concept was beginning to develop in the minds of the Japanese. If their pilots faced almost certain death while attacking the American fleet, then would it not be better to deliberately crash into an American ship to insure that it would either be sunk or forced out of the battle? The first kamikaze special attack force was organized on 20 October 1944 with twenty-six zero fighter-bombers, thirteen of which were designated for the suicidal attack. ${ }^{146}$

In October 1944, ferret missions over the proposed invasion approaches to Leyte revealed the Japanese had

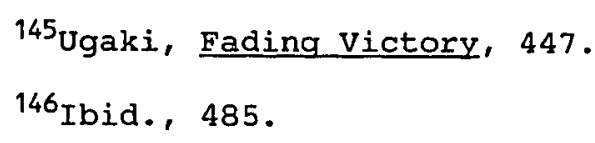


operating radars on the islands of Dinagat, suluan and Homonhon, which guarded the approaches to Leyte Gulf. The first offensive action by the Americans was to neutralize these radar installations. On 17 October 1944 specially trained units landed and took control of these radar sites within twenty minutes, effectively blinding the Japanese. ${ }^{147}$ However, this action also alerted the Japanese to the obvious location of the upcoming landing. On 18 October 1944 Admiral Toyoda gave the order to execute Operation "Sho-1." 148

The Battle of Leyte Gulf was the largest naval battle in history. The actual battle consisted of four separate but inter-linked naval actions. In the traditional complexity of Japanese naval planning, each phase of the battle was co-dependant upon the success of all the other elements involved, according to a precise time table. For the Americans, radar would once more play an important part in the tactical outcome of the battle.

The landing on Leyte was conducted on 20 October 1944, with three hundred American transports under the command of Vice Admiral Thomas C. Kinkaid of the 7th Fleet. Supporting the landing operation were the older battleships under the

\footnotetext{
${ }^{147}$ Stewart, Leyte Gulf, 28.

${ }^{148}$ Hamilton, War at Sea, 233.
} 
command of Rear Admiral Jesse oldendorf. While the landing operation was underway, Admiral Halsey's 3rd Fleet continually attacked the airfields in the Philippines. Admiral Halsey's assignment was to provide a defensive screen, using the newer battleships, should the Japanese Navy appear. Halsey knew that once the landings were underway, the Japanese would sortie to oppose the American incursion.

From the InIand Sea, Vice Admiral Ozawa's carrier force sailed for the northern end of Luzon. Ozawa had 116 aircraft, and these he quickly committed into the battle. His "rookie" pilots attempted to engage the Americans over the island airfields. They were promptly shot down by the more experienced Americans, and this stripped Ozawa's Mobile Fleet of four attack carriers and two hybrid battleships of any effective air cover. 149

Vice Admiral Kurita's First striking Force included five battleships, Yamato, Musashi, Nagato, Kongo and Haruna. The powerful armada sailed from its singapore anchorage along with ten heavy cruisers: Atago, Chokai, Myoko, Kumano, Chikuma, Takao, Maya, Haguro, Suzuya and Tone. Fifteen destroyers sailed as escort for the heavy ships. Kurita's orders were to sail through sibuyan sea and enter san

${ }^{149}$ Pemsel, History of War at Sea, 145 . 
Bernardino strait. He would pass through the strait and wheel southward to attack the American amphibious force from the west.

The Southern Force was comprised of two separate battle groups. The first group, commanded by Vice Admiral shoji Nishimura, included the battleships Yamashiro and Fuso, the heavy cruiser Mogami and four destroyers. A smaller force, commanded by Vice Admiral Kiyohide Shima, included the heavy cruisers Nachi, Ashigara and Aoba, two light cruisers and nine destroyers. Shima's force was to join Nishimura, and the combined force would pass through the surigao strait to cut off American ships attempting to escape from Kurita's First striking Force. The Japanese did not know that the Americans had become quite proficient in the fields of signal and cipher intelligence. The Americans knew the Japanese were coming, and planned a trap of their own. Admiral Kinkaid's 7 th fleet was dispatched to block the Surigao strait to prevent any Japanese threat to the landing beaches from the southern approaches. Admiral oldendorf's six support battleships were positioned across the mouth of the strait to wait in ambush. Remaining with the transports and cargo vessels of the amphibious operation were eighteen escort carriers. Six, as Taffy-1, guarded the amphibious ships. Taffy-2 and Taffy-3 were to provide close air support for the troops ashore. Each of the escort carriers 
carried twelve to eighteen $\mathrm{F} 4 \mathrm{~F}-4$ wildcat fighters and twelve TBM-1 Avenger torpedo bombers. Three destroyers and three destroyer escorts provided the anti-submarine screen for each Taffy group.

During the day of 21 October 1944 Japanese land-based aircraft sortied against the American forces. Radar aboard the light carrier Princeton picked up the incoming bogeys and forty-three fighters were scrambled to augment a CAP of twelve Hellcats. The Hellcats became embroiled in an aerial skirmish and thirty-one of the enemy planes were shot down. Radar on Princeton detected another wave of inbound aircraft. The formation contained thirty-four enemy aircraft and the American fighters, which were low on fuel and ammunition, engaged. None of the enemy broke through to the task force. With the threat eliminated, the American fighters were ordered to land. In the confusion of numerous aircraft circling to land the task force radar screens became clutterea. A single Judy dive bomber slipped though the radar net and planted a five-hundred-pound bomb onto the flight deck of princeton. The bomb penetrated the flight deck and exploded on the hangar deck which was strewn with fuel hoses and ordnance. Secondary explosions rapidly forced the princeton to be abandoned. 150 
On 23 October 1944, two American submarines, Darter and Dace, were patrolling the waters off Palawan Island. Darter picked up Kurita's First strike Force on radar at 0630 hours and positioned itself for a torpedo attack.151 At 0632 hours, while only 980 yards from the lead cruiser, it fired a spread of six torpedoes. Atago, Kurita's flagship, was hit by four torpedoes and staggered to a halt. Turning 180 degrees, Darter fired four torpedoes from its stern tubes at the next cruiser. Two torpedoes hit the heavy cruiser Takao. 152 While Darter was conducting her attacks upon the Japanese cruisers, Dace moved into position and fired its own spread of torpedoes at the cruiser Maya. The Japanese heavy cruiser exploded and sank within four minutes. 153 The two damaged cruisers were forced to retire from the field. Admiral Kurita transferred his command to the battleship Yamato and continued forward in spite of his loss of three major warships. He entered the Sibuyan sea and approached San Bernardino strait during the daylight hours of 24 October 1944. The Japanese naval air units, or what was left of them, had sortied northward on the 24 th of October in an attempt to locate and attack the

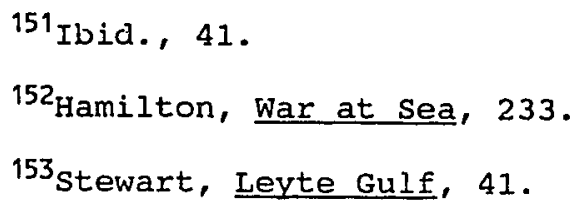


American carriers.

Since the Japanese Army air units were still not cooperating with the Japanese Navy, Kurita's central force was now without aircover. The lesson had been taught by the Japanese themselves when they sank Repulse and Prince of Wales off the Kuantan Peninsula on 10 December 1941. To sortie without air cover in the age of aircraft was an invitation to disaster. At approximately 1020 hours, Japanese radar picked up incoming bogeys. The strike was comprised of twenty-one Hellcat fighter-bombers, twelve Helldiver dive bombers and twelve Avenger torpedo bombers. To the American pilots, the target of choice was obvious. There were two monster-sized battleships in the Japanese van. The American strike group commenced to attack the Japanese leviathans while calling for help. 154 A second wave of attackers arrived and chose Musashi as their target. Four torpedoes hit Musashi as did two bombs. Musashi's speed was reduced to twenty-two knots, and it was obvious to the American pilots that the huge ship was having difficulty maneuvering. At 1330 hours a third wave of American aircraft arrived. Some of the American strike group selected the other monster, Yamato, and hit it with several bombs, but the wounded Musashi took the brunt of the attack.

\footnotetext{
${ }^{154}$ Ibid., 64.
} 
Musashi was hit with four more torpedoes and four more bombs. The large battleship slowed to twelve knots and began to settle by the bow. Obviously crippled, Musashi inadvertently became a sacrificial goat to save the remainder of the Central Force. To the attacking American airmen it was an open invitation. They piled on and Musashi was hit by eight torpedoes and eleven bombs. Musashi, one of the two most powerful battleships in the world, went dead in the water and continued to settle by the bow. At 1935 hours it capsized and sank.155. It had taken a combined total of 226 American strike planes to hit Musashi with nineteen torpedoes and seventeen bombs. But Musashi had been armed with 120 defensive guns of various calibers and didn't go down without a fight. The anti-aircraft guns accounted for eighteen of the American attackers. 156 Admiral Kurita was shocked by the sinking and ordered a reversal in the course for the First strike Force, making the Americans believe the Japanese were retiring from the field of battle.

Admiral Halsey received word that Kurita was retreating. He knew a strong Japanese force was approaching Surigao strait, and another carrier force was approaching

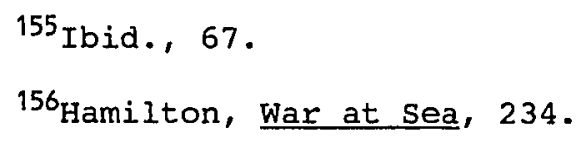


from the north. Admiral Halsey had no way of knowing that Ozawa's northern group of carriers was a defenseless decoy. Kinkaid's 7 th Fleet had already been sent to protect the southern approaches to the landing beaches. Oldendorf's force of six of the older battleships was in a blocking position across the mouth of the surigao strait. Therefore, Halsey felt justified in responding to the more dangerous threat, Ozawa's carriers. He ordered TF-38, the fast battleship reaction force, along with Vice Admiral Mitscher's attack carriers, to rush northward to attack ozawa. Halsey's decision left the thin-skinned escort carriers of Rear Admiral C.A.F. Sprague's Taffy-3 in an exposed position, protected by a few destroyers the aircraft aboard the small carriers. If the Japanese could capitalize upon the opportunity, they could deal the American forces a major defeat. Admiral Kurita had already reversed his course and was rushing for the San Bernaraino strait with Yamato and the remainder of the First strike Force battleships and heavy cruisers.

At 2300 hours on 24 October Admiral Nishamura's Southern Force entered Surigao strait. Waiting in ambush were thirty-five American PT boats, invisible against the blackness of Pananon and Dinagat Islands which formed the 
approaches to the strait. ${ }^{157}$ Aboard the small plywood patrol boats the skippers watched their radar sets as the large battleships, in consort with their cruisers and destroyers, formed a line. The order to attack was given, and from both sides the tiny adversaries rushed in to launch torpedoes. Unlike their European contemporaries, who launched their torpedoes while their boats lay at rest, the American PT boats torpedo attacked as though conducting a cavalry charge, roaring in towards their victims at thirty knots to launch torpedoes at point blank range before sheering off to escape defensive gunfire. In the blackness of the strait, with the PT boat bouncing up and down and from side to side, accuracy was nearly impossible. Although the attack seemed directly out of a Hollywood movie script, it was also highly dangerous. A single five-inch shell from a destroyers gun could turn the plywood PT boat into kindiing wood and a number of the American boats were reduced to instant flotsam while making their attacks. only one Japanese warship suffered the indignity of being hit by a PT torpedo that night. The primary objective of the PT boats was to provide Admiral Kinkaid's 7 th fleet with advance warning. In that the PT boats were successful. 158

\footnotetext{
${ }^{157}$ Pemsel, A History of War at Sea, 146.

${ }^{158}$ Hamilton, War at Sea, 235.
} 
By 0300 hours on 25 October 1944 the last Japanese warship had passed through the gauntlet of PT boats, only to face a more deadly threat. Lying in wait, on either side of the narrow strait as it opened into Leyte Gulf, were three American destroyer divisions. In the blackness of the night, within the confined waters of the strait, the American destroyer commanders watched the Japanese approach on their radar scopes. The order was given to commence the torpedo attack, and the destroyers rushed unseen towards their Japanese adversaries, which were still approaching in line astern formation through surigao strait. Twenty-sever torpedoes sped undetected towards their victims. The battleship Fuso was cut in half by one or more torpedo hits. The destroyer Yamagumo erupted in a sheet of flame. The second American destroyer division commenced its torpedo attack at 0323 hours. The officers in command watched as their torpedoes struck and sank two Japanese destroyers. Fuso lay unmoving, a burning pyre which illuminated the surrounding area. The flagship Yamashiro continued to rush forward, followed by the heavy cruiser Mogami and the destroyer Shigure. 159

Steaming back and forth across the Japanese Iine of approach were the six American battleships--Tennessee, West 
Virginia, California, Pennsylvania and Mississippi--of Admiral oldendorf's bombardment group. In addition to the older battleships, there were seven cruisers of the 7 th Fleet's support force. Aboard the American battleships and cruisers, radar provided accurate data on the course, speed, range and bearing for the approaching enemy warships. This information was relayed to the primary batteries to adjust the fire control computers. At 0353 hours the American battle line erupted in flame as the battleships discharged their fourteen-inch guns. Admiral oldendorf had achieved the ultimate dream of every battleship admiral in the world, that of crossing the "T" with an enemy force. Yamashiro fired back with the only guns available, the forward batteries. As the Japanese battleship turned from side to side in an attempt to elude the American shells, it was hit repeatedly. The heavy cruiser Mogami also began to take hits. Yamashiro went dead in the water, while Mogami turned about to rush back down the strait. At 0419 hours Yamashiro capsized and sank. ${ }^{160}$

Admiral Shima's smaller force had not passed through the PT boat gauntlet unscathed. The light cruiser Abukuma was severely damaged during the PT boat torpedo attack. Coming upon the flotsam of the battle Admiral Shima realized

${ }^{160}$ Ibid. , 236. 
that a naval debacle had taken place. He ordered a reversal in course. Mogami, which was steaming back through the strait at flank speed, collided with the cruiser Nachi and damaged its stern. The entire Japanese force turned about and retired with the American cruisers and destroyers following in hot pursuit. The destroyer Asagumo, which had lost its bow during the torpedo attacks, was quickly caught and dispatched by the American pursuers. The following morning, United States Army Air Force bombers caught Mogami and Abukuma. Abukuma was sunk, while the Japanese were forced to sink the damaged Mogami. Of the southern force, only two Japanese cruisers and a few destroyers escaped unscathed. 161

During the night or 24-25 October 1944, just prior to the Battle of Surigao strait, a radar-equipped Avenger, which had been sent to patrol San Bernardino strait, detected and reported at 2030 hours the movement of several large surface vessels approaching the strait at twenty knots. Halsey ignored the intelligence report and continued to steam northward to engage the Japanese carriers known to be north of the island of Luzon. At 2120 hours another radar-equipped snooper reported Kurita's Central Force off Aguja Point. Again, Halsey chose to ignore the report, even

\footnotetext{
${ }^{161}$ Pemsel, History of War at Sea, 147.
} 
though it indicated Kurita was moving through the strait with his battle group of four powerful battleships, including Yamato. 162

At 0645 hours on 25 October 1944 the pilot of an American Avenger which had just taken off to perform a dawn patrol reported four battleships, eight cruisers and a number of destroyers bearing down on the Leyte landing beaches at a distance of approximately twenty miles. Rear Admiral Sprague's Taffy-3, with its six escort carriers and seven destroyers, was the only American defensive force standing in the way of the Japanese. The American admiral had just enough time to order all available aircraft scrambled, a maneuver that required him to turn into the wind and steam towards the approaching enemy. At 0658 hours, Yamato, along with its consorts Nagato, Kongo and Haruna, began to fire at the American carriers. The action was perhaps one of the most lopsided of the war in terms of firepower, for the little escort carriers could only respond to Yamato's nine, eighteen-inch guns with single, five-inch guns which were mounted on the sterns. The problem facing the escort carriers was that before they could return fire the massive battleship had to get within range of the

\footnotetext{
${ }^{162}$ Stewart, Leyte Gulf, 89.
} 
carrier's five-inch gun. 163 A carrier's primary weapon is the airplane. The wildcat fighters six .50 caliber machine guns could do little against the armor of a Japanese battleship but the Avengers were far more lethal as they carried torpedoes. Once the aircraft had been scrambled, the only alternative remaining to Admiral sprague was attempt to escape from the enemy as fast as he could; at flank speed the escort carriers could only make seventeen knots. Yamato could make twenty-seven knots.

Although Yamato was equipped with radar, the Japanese were not using the technology to direct theix primary guns onto the little carriers. Perhaps this was due to the primitive state of Japanese radar. This allowed Taffy-3 to run for a nearby rain squall while the escorting destroyers made smoke to screen their charges from view. The tactic worked for a short time as the massive shells straddled the small carriers.

Taffy-2, which had been alerted to the plight of Taffy3 , began to launch its aircraft to defend the extremely vulnerable flotilla. When Kurita, aboard Yamato, saw the flat decks of the carriers and the silhouettes of the aircraft being launched, he surmised that he had stumbled onto part of Halsey's 3rd Fleet attack carriers. Kurita

\footnotetext{
${ }^{163}$ Gardiner, Conway's All the Worlds Fighting Ships, 109.
} 
ordered his cruisers to intercept the carriers. At this moment the destroyers of Taffy-3 reversed course and made a concentrated torpedo attack against the Japanese warships. The destroyer Johnston was hit by heavy caliber shells, but not before she had launched her torpedoes at yamato and Nagato, forcing both battleships to swerve away from their line of approach, disrupting their gunfire. The American destroyer Hoel was also hit, but its torpedoes forced Kongo to turn to avoid them and this disrupted the battleship's gunfire against the small carriers. The destroyer S.R.Roberts was hit by heavy-caliber gunfire and sank. The escort carrier Gambier Bay was initially straddled by the heavy rounds, but ultimately took hits and sank within minutes. before taking hits, and within minutes. The escort carriers Fanshaw Bay and Kalinin Bay were hit by the heavy shells; although heavily damaged they managed to survive. The main thrust of the American destroyers caused Admiral Kurita to lose control of his formation as his ships were forced to maneuver to avoid torpedoes. Still, victory was within Kurita's grasp.

A single escort carrier could only offer a meager defense with its torpedo bombers, but in combination with other escort carriers a considerable force could be applied. All available aircraft from the three Taffy groups, a total of 216 torpedo bombers, converged on the ships of the 
Central Force. At 0830 hours the Americans began a coordinated attack upon the Japanese surface formation. Almost immediately the heavy cruisers Chikuma and chokai were sinking wrecks. Suzuya was damaged and the remaining American destroyers charged in to attack any Japanese ship afloat. Kumano was hit by several torpedoes fired from Johnston and Kurita realized that if he continued, his powerful force would be wiped out. If the attacking aircraft were, as he believed, from Halsey's attack carriers, then Halsey's fast battleships couldn't be far behind. Kurita ordered a reversal in course and limped away •

It was a daylight battle, fought at almost point-blank range. Radar, if it was used at all, would have been on the American destroyers directing the five-inch batteries against the Japanese warships. Unfortunately, a five-inch gun was of little value against the heavy armor of a Japanese battleship. Torpedoes were the primary weapon of effect in the Battle off Samar Island, and they scored heavily.

At the moment Kurita fell upon Taffy-3 off Samar Island, Admiral Halsey was engaging the carriers of Admiral Ozawa's northern decoy force. At 0810 hours aircraft from Admiral Mitscher's carriers attacked chitose and its destroyer escort. The Japanese carrier and its escort both 
sank by 0937 hours. The American airmen were opposed by twenty-nine zeros, the entire complement of aircraft from all of the Japanese carriers. Both zuikaku and Zuhio were attacked and hit by bombs and torpedoes. At 0945 hours a second wave of American carrier planes attacked. Chiyoda went dead in the water at 1012 hours. Zuikaku was hit by three torpedoes and capsized. American aircraft flew shuttle missions to attack and then return to their carriers for more bombs or torpedoes. During the operation, Halsey heard the calls for help from Taffy-3 which were being sent in the clear. In response to Sprague's pleas for help, Halsey ordered Vice Admiral Willis "Ching" Lee's battle line to reverse course to cut Kurita off at San Bernardino strait. Halsey thought it was stupid, but he felt he had to respond to Sprague's repeated requests. Because he was too far away to do anything constructive, he continued his carrier attack upon Ozawa's decoy force. At 1445 hours a fourth wave attacked the damaged zuhio and sent her to the bottom. The Battle off Cape Engano ended at 1630 hours when several heavy cruisers from the 3rd Fleet arrived and dispatched Chiyoda with naval gunfire. ${ }^{164}$ Again, radar in the northern battle had little impact upon the outcome of the battle, for the battle was fought during daylight hours,

\footnotetext{
${ }^{164}$ Hamilton, War at Sea, 239.
} 
in clear weather, with overwhelming American power.

The Battle of Leyte Gulf introduced the Americans to a new and terrifying weapon, that of the kamikaze special attack forces. On 25 October 1944, a Japanese airplane was seen to dive deliberately onto the flight deck of the escort carrier Santee which was attached to Taffy-1. The plane, which carried a bomb, penetrated the flight deck and into the hangar where it exploded and caused extreme damage. At 1050 hours, at the height of the Battle off Samar Island, the escort carrier Suwanee was hit by a kamikaze plane. Fortunately, the damage was light and suwanee was back in action within two hours. Five more kamikaze attackers lashed out at Taffy-3, successfully hitting the escort carriers Kitkum Bay and st.Lo. Fitkum Bay was quickly repaired, but st. Lo was mortally wounded and foundered by 1106 hours. That the kamikaze were so successful was perhaps because the escorting destroyers were engaged with the heavier Japanese warships and could not use their radarcontrolled five-inch guns to defend the escort carriers against suicidal aircraft. The radar carried by the escort carriers was for early warning and intercepts. It is highly doubtful that any fighter director officer aboard the little carriers would have had the time, while his vessel was being straddled by fourteen-inch and eighteen-inch shellfire, to 
direct his fighters to any aerial defense of the ship. 165

${ }^{165}$ Ibid., 239. 
Chapter 10

okinawa

It was the kamikaze threat which brought about significant changes in the composition of the U.S. task force. Destroyers were positioned over the horizon, sixty to ninety miles from the perimeter of the task force to form an early-warning radar-picket line. ${ }^{166}$ At a distance of approximately twenty miles from the core of the task force a ring of destroyers then formed the outer anti-aircraft shield. Within this shield, at a distance of ten miles, an inner anti-aircraft defensive shield was established with the heavy and Iight cruisers. Each sub-task-force group contained two attack-class carriers and two light carriers. The new battleships steamed as a special, rapid-response anti-aircraft, sub-task-force group and would be positioned across the suspected line of approach of any enemy aircraft. The destroyer-pickets were assigned the duty of detecting incoming enemy aircraft and setting up the initial anti-aircraft barrage defense. Unfortunately, the inexperienced pilots who comprised the special attack units,

\footnotetext{
${ }^{166}$ Ibid. , 256.
} 
when they realized they could not reach the American task force with its plethora of large targets, would single out the nearest American ship to attack, one of the destroyerpickets. In the following months these destroyers bore the brunt of the kamikaze attacks, but also shot down many of the enemy attackers.

The taking of the Philippines by General. MacArthur's Army forces was a long, drawn-out campaign. The Japanese were effectively shuttling troops and supplies to the island archipelago, and the Japanese Army Air Force was conducting nightly raids upon the American troops. In November 1944, General MacArthur asked the Navy to post four Marine night fighting squadrons to help defend the Army. The request was granted and nocturnal attacks by Japanese intruder bombers were reduced to more tolerable levels. 167

As the battle for control of the Philippines moved forward, the United States Navy began to experience more frequent attempts by Japanese aircraft of the special attack forces to crash upon the decks of its major warships. In spite of the advantage of early warning radar, fast fighters, and radar-controlled anti-aircraft fire using the proximity shell, the kamikazes occasionally got through to the American ships.

${ }^{167}$ Ibid. , 241. 
What the Americans did not know was that on 1 October 1944 a special kamikaze unit had been formed to deploy a rocket-powered glide bomb which could be guided into an American ship by a volunteer pilot. The flying bomb, constructed from plywood, was named oka ("Cherry Blossom") by the Japanese. ${ }^{168}$ The range of the oka was limited to approximately twenty-three miles, but the five rockets mounted in the tail allowed the little manned predecessor to the smart bomb to achieve speeds up to $576 \mathrm{mph}$ in a shallow dive. Because of the limited range of the oka, a host aircraft was required to carry it to a point where it could reach the American fleet. Once the flying bomb was released from its host, usually a Betty bomber, the Americans could do little to prevent the human-guided, 2,500-pound warhead from impacting into its victim. ${ }^{169}$ The only defense was to intercept the host aircraft before it reached the release point; in this, radar could be and was effective when a CAP with enough fighters was vectored to engage the approaching host bombers.

By mid November, fifty of the oka bombs had been rushed through production and were ready for shipment to the

\footnotetext{
${ }^{168}$ Ikuhiko Hata and Yashuho Izawa, Japanese Naval Aces and Fighter Units in World War II, trans. Don Cyril Gorham (Annapolis: Naval Institute Press, 1989), 226. ${ }^{169}$ Weal, Combat Aircraft of World War II, 177.
} 
Philippines. These were loaded aboard the shinano, the newest Japanese carrier which was scheduled for a shakedown cruise from Yokosuka to Kure on 28 November 1944. Shinano was the third Yamato-class super-battleship hull laid down by the Japanese. However, by the time the hull of the Shinano had been completed, it was obvious that battleships were no longer the key to success in naval engagements; therefore the large hull was reconfigured as an aircraft carrier. Although Shinano would be the largest aircraft carrier in the Japanese fleet, it would only carry twenty fighters, twenty bombers, and seven torpedo bombers, about the complement of an American light carrier. For the shakedown cruise the Japanese carrier did not ship any aircraft other than the oka bombs.

At 1915 hours, on 28 November 1944, Captain Toshio Abe, as commander of Shinano, was informed that his radar detection gear was picking up radar emissions from a source which lay on the surface at a distance of approximately twelve miles. Captain Abe incorrectly assumed that he was being tracked by a submarine wolf pack of eight-to-twelve submarines. He ordered Shinano to commence a zig-zag, antisubmarine course pattern. Commander Joseph F. Enright, aboard the submarine Archerfish, watched the large blip change course on his PPI radar scope and then change course again. Logically assuming the large contact would follow a 
predictable pattern, Enright ordered Archerfish to flank speed to perform an end-run maneuver, which would have been impossible had Shinano continued straight ahead. Archerfish positioned itself for a radar-controlled torpedo attack. At 0317 hours on 29 November 1944, Captain Enright fired a spread of torpedoes at Shinano from a range of thirteen thousand yards. Four torpedoes impacted into shinano, and the brand new carrier, with an inexperienced crew and no procedures for water-tight integrity, sank within a few hours.170 When Commander Enright sank the Shinano, he deprived the Japanese Navy of a carrier which carried no aircraft. But with the help of radar he possibly prevented a major disaster in the Philippines because the entire production of oka bombs went down with the carrier.

The kamikaze tactic also caused a change in the tactical doctrine aboard the task force carriers. Carrier fighter strength had to be increased, and the United states Navy looked for a source for highly-skilled, combat seasoned pilots. The answer was provided by the United states Marine Corps fighter squadrons which were sitting on the various backwater islands of the South Pacific. Not only were the Marine pilots highly skilled combat veterans, but they were

170 Joseph F. Enright, CAPT. USN and James W. Ryan, Shinano: The Sinking of Japan's Secret Supership (New York: St. Martin's Press, 1987), 
already equipped with a first-rate fighter, the corsair, which was equal, if not superior, to the Hellcat. Combat expediency often tears through the barriers of resistance, and the American Navy gladly accepted the Marines with their Corsair fighters into the carrier air groups.

Included in the new aircraft complements were radarequipped Avenger and Hellcat squadrons specifically trained for night intrusion missions. Restrictions on the night fighter detachments had been lifted because of the threat of night kamikaze attacks, and the night fighter pilots quickly reclaimed their skills at night combat. As the proficiency of the night fighter pilots improved, they became deadly adversaries with their ability to see electronically in the dark. If it was nearly impossible for a Japanese aircraft to sortie during daylight hours, it was now virtual suicide for any Japanese pilot to venture aloft after nightfall. The most vulnerable aircraft were the Japanese utility planes, especially the Tabby, a Japanese version of the old Douglas DC-3 airliner. ${ }^{171}$ As a Tabby approached a landing field at night with its cargo of supplies and/or personnel, it was common for one or more of the radar-equipped night fighters to follow it on the descent. The Japanese utility plane, when followed by a night fighter, seldom touched down

\footnotetext{
$171_{\text {Tillman, Hellcat, } 183 .}$
} 
on the landing strip because the night fighter would fire a lethal burst from its .50 caliber machine guns. The Tabby usually crashed in a spectacular ball of flame on the approach end of the runway.

By 29 January 1945 the British Fleet arrived to complement the American task forces. Although the British contribution was only a fourth the size of the American naval presence, the British naval units were welcome additions. It had been previously decided that the British task forces would operate independently from the American task forces, although a joint effort to neutralize a particular target was not uncommon. The biggest difference between the American carriers and their British counterparts was that the British carriers were equipped with armored flight decks, which made them almost impervious to kamikaze hits. Although British carriers were successfully targeted by Japanese suicide planes on several occasions, they were brought back to operational status within a few hours after being hit. 172 The British also operated American lendlease aircraft, the Hellcats, Avengers, Helldivers and Corsairs, which were common to both Allied forces. The British deployed their own version of radar wizardry in their night intruders and night fighters. The radar carried

\footnotetext{
${ }^{172}$ Hamilton, War at Sea, 246.
} 
by the British night fighters, slightly superior to the radar carried by the American naval counterpart, had a range of fifteen miles. This comparison did not apply to the American P-61B Black Widow, which had been designed specifically as a night fighter. The latest P-61B variant used a new SCR-720C airborne-intercept radar with a phenomenal range of approximately one hundred miles. The radar operator was also presented with a clearer image display. The pilot was given a night binocular system, combined with an optical gunsight using a pair of dots superimposed on the gunsight glass. This gunsight allowed the pilot to determine the range to his victim with far more accuracy than before. The first P-61B production models were also fitted with an APS-13 Tail Warning Radar, but in the Pacific the electronic emission sensor was not required. The same production models of the $\mathrm{P}-61 \mathrm{~B}$ were also used as test beds for the Western Electric APG-I gun-laying radar in the dorsal turret. However, the pilots of the deadly new night fighter preferred to keep the dorsal turret with its four .50 caliber machine guns locked in the forward firing position to add maximum effect to the concentrated fire from the four $20 \mathrm{~mm}$ cannon mounted in the fuselage. 173 As rapidly as they became operational, P-61 night fighter

${ }^{173}$ Davis and Menard, Black Widow, 23. 
squadrons were deployed to the Philippines and then to the island airfields to support American Army units. In addition to the nocturnal role of a radar interceptor, P$61^{\prime} \mathrm{s}$ were fitted with six bazooka rockets, usually configured with three tubes tied together, or with launch rails for eight five-inch HVAR rockets.

The Black Widows would prowl the skies over the Pacific islands as free-lance intruders seeking out soft targets, trucks and trains used by the Japanese to supply their forward units. The intruder missions were deadly to the Japanese. The large fighter would pounce without warning and use the HVAR rockets to destroy the lead vehicle of a truck convoy. Then, using the flames from the first victim as a beacon, the nearly invisible fighter would strafe, rocket and/or bomb the concentrated targets of opportunity which cluttered the road.

From their bases on Saipan and Tinian in the Marianas, General Curtiss LeMay's 21st Bomber Group began to pound the Japanese home islands by day and by night using the B-29 bomber. One of the advantages of the B-29 was that it carried a radar bombsight which was capable of navigation as well as accurate target acquisition. Although the B-29, when flying at its operational altitude above twenty thousand feet, was impervious to all but the most modern of the Japanese interceptors, the results of high altitude 
bombing were ineffective. General LeMay realized that his bombers would have to release their bombs from lower altitudes. He ordered his pilots to drop their bombs from a height lower than ten thousand feet. The destruction of Japanese targets improved, but the losses in bombers increased because the bombers were now vulnerable to Japanese interceptors and anti-aircraft gunfire. To force the Japanese to surrender, the war would have to be brought directly to the civilian population by maximizing the bombing effort.

Houses constructed of wood and paper are extremely vulnerable to fire. The precedent of dropping incendiary bombs upon enemy cities had already been established in Europe, and General LeMay turned to incendiary fire-bombing raids with a vengeance. On the night of 9 March 1945 the first incendiary raid was conducted against the Japanese capital of Tokyo. The initial B-29 pathfinder bombers flew over the target area at an altitude of five thousand feet while using their radar to navigate to the target. The first "pathfinder" bombers dropped incendiaries to outline a sixteen-mile-square rectangle in the center of the city. The next group of pathfinder bombers marked a large " " across the outlined rectangle. Subsequent bombers were ordered to drop their loads of incendiaries, which used a new "jellied gasoline" (napalm) intermixed with heavy 
explosives to spread the burning mixture over a greater area within the target. 174 The resulting fire-storm killed 83,793 civilians. The fire raid was justified when the after-strike photos revealed a forest of lathes, drill presses and milling machines where Japanese homes had once stood. 175 An entire "cottage" industry had been destroyed, and the incendiary tactic became the operational standard for LeMay's command to systematically destroy every large city in Japan. 176

The projected Iosses in B-29 bombers as a result of the low level raids indicated a need for fighter escorts. Airfields would be needed within the combat radius of the escorts and for emergency use by the B-29's which suffered mechanical failure or battle damage. The island of Iwo Jima was ideally located for both the forward fighter airstrips and emergency landing fields.

The initial assault on the island began on 19 February 1945. As the U.S. Marines swarmed ashore, Japanese kamikaze attacks increased against American ships. The carrier Saratoga sustained seven kamikaze hits. During a night

\footnotetext{
${ }^{174}$ Michael Sherry, The Rise of American Air Power: The Creation of Armageddon (New Haven: Yale University Press, 1987), 228.

${ }^{175}$ Edward Jablonski, Epic of Flight: America in the Air War (Alexandria: Time Life Books, 1982), 167.

${ }^{176}$ John W. Dower, War Without Mercy: Race and Power in the Pacific War (New York: Pantheon Books, 1986), 232 .
} 
attack the carrier Bismarck Sea was sunk. The island was finally secured on 26 March 1945, and soon after the emergency runways became operational. When the first fighter squadrons arrived on the island, they included the Army's 549th night fighter squadron flying the P-61B.177

As the American Navy began to attack Japanese airfields to reduce the number of aircraft which could be used to defend okinawa, the Japanese increased kamikaze attacks against the American carriers. On 21 March 1945, the oka bomb was used for the first time against American Naval units. Eighteen Betty bombers, each carrying one of the deadly little human-guided glide bombs, sortied out to attack TF-58.1. The Japanese realized the host bomber had to get the oka to a release point within the twenty-one mile range of the manned glide bomb. Therefore, thirty zero fighters were assigned to escort the Bomber hosts to their release points. At seventy miles, the radar aboard the Hornet picked up the incoming formation and a combined CAP from Hornet and Belleau Wood was vectored to intercept. The Hornet fighters took on the bombers, while the Hellcats from the Belleau Wood went after the Zeros. Within twenty minutes, all eighteen host bombers had been shot down before they could release their deadly cargos. The effectiveness

\footnotetext{
${ }^{177}$ Davis and Menard, Black Widow, 29.
} 
of early-warning radar, fighter-director-officer-procedures and well-trained pilots flying one of the best fighters of the war, had prevented a major disaster. ${ }^{178}$

Okinawa was seen by the Japanese as a part of the Japanese homeland. Therefore, for the defenders, there would be no respite in a final fanatical battle for Japanese honor. Death was preferable to defeat. The kamikaze would be the last desperate effort to dislodge the American invaders, and they could and would operate from hundreds of airstrips within range of the sixty-mile-long island. For the Americans, the assault force to take the island would be the largest of the entire war, and radar would be a major contributor to the outcome of the battle. On 1 April 1945, three divisions of the United states Marine Corps and four divisions of United States Army Infantry swarmed onto the beaches of Okinawa. By nightfall there were fifty thousand American troops ashore and supplies were being stockpiled on the beaches. A total of 1,213 ships filled the waters off the landing beaches. 179

As soon as the beach-head was secured the United states Marines began to construct airstrips from which they could operate their fighter-bombers. The Marines also deployed

\footnotetext{
1?8. Iiliman, Heilcat, 209.

${ }^{179}$ Hamilton, War at Sea, 255.
} 
three night fighter squadrons, $\operatorname{VMF}(\mathrm{N}) 533,542$ and 543, to support the okinawa campaign. However, unlike their dayattack brethren, the Marines flew a new F6F-5N Hellcat which had four $20 \mathrm{~mm}$ cannon and four .50 caliber machine guns as well as a more effective radar system. The Marine night fighters were principally assigned to the defend Allied forces on the island and they operated with a GCI radar station equipped with long range radar. The Marine ground controllers worked with the Marine pilots to make a proficient combat team and the kill rate of the night fighters increased aramatically. 180

Lieutenant General Mitsuru Ushijima, the Japanese officer charged with the defense of okinawa, realized his only hope would be the kamikaze special attack forces. He also realized that the most damage could be inflicted upon his enemy by attacking the plethora of support ships anchored off the landing beaches. Ushijima waited for the right moment to attack. At sea, the American Navy had established a perimeter of sixteen radar pickets posted at a distance of eighty-five miles from the assault armada. ${ }^{181}$ The pickets were Fletcher class destroyers which carried

\footnotetext{
${ }^{180}$ Tillman, Hellcat, 188.

${ }^{181}$ Hamilton, War at Sea, 257.
} 
five five-inch, dual-purpose guns in single mounts. ${ }^{182}$

The five-inch guns were linked into a radar-fire-control system and used proximity fused shells. The main purpose of the radar pickets was to provide an early warning of any aerial attack upon the invasion fleet. The Americans simply did not realize the numbers of suicidal airmen they would face.

By 6 April 1945, fighting on the island had bogged down due to the fanatical resistance of the Japanese defenders. General Ushijima decided the opportunity to inflict a major, perhaps fatal, wound upon his adversaries was at hand. The initial air attacks were initiated during daylight hours with seven hundred enemy aircraft. A total of 355 kamikaze took part in the operation. ${ }^{183}$ The disastrous operation on 21 March 1945 had convinced the Japanese that it would be more profitable to carry the oka glide bombs in host bombers flying with the conventional attack aircraft. ${ }^{184}$ The radar picket destroyers performed their task, and the incoming waves of Japanese aircraft were picked up in time to allow the fleet carriers to vector their fighters to intercept the attackers. The first clash resulted in

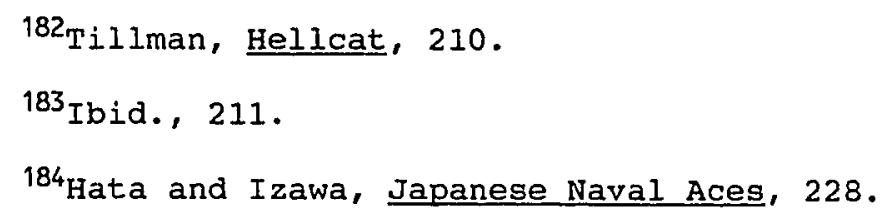


approximately ninety Japanese aircraft being shot down, but the sheer force of numbers allowed a few of the dedicated Japanese pilots to get through. Unfortunately, when a fanatical pilot realizes that he cannot crash onto the deck of an American aircraft carrier, then logic implies that the same effect could be achieved by crashing into any available American ship. For these suicidal pilots, the only American warships in sight were the little picket destroyers. In spite of their radar-controlled anti-aircraft defense and high-speed evasive maneuvers, destroyers Newcomb and Leutze were hit by kamikaze aircraft. Although neither destroyer was sunk, the damage was sufficient to force their retirement from the field of battle. Not so lucky were the destroyers Bush and Colhoun. Throughout the day the frustrated Japanese dove into the small destroyers, eventually sinking them. A few enemy aircraft got through to the periphery of the landing forces where they sank a landing-ship-tank, two ammunition ships and three more destroyers while seriously damaging eight destroyers and two other ships. None of the oka host bombers reached their launch points successfully.185 At least 344 Japanese aircraft were destroyed that day. The Japanese continued to attack at night and American night fighters shot down nine

${ }^{185}$ Hamilton, War at Sea, 257. 
of the Japanese aircraft.

Three more kamikaze raids were mounted by the Japanese in April, four in May and two in June. The raids numbered in size from forty-five to almost two hundred aircraft. Although radar provided sufficient time for the defensive fighters to intercept and decimate the enemy formations, a few of the Japanese planes always managed to get through. On 12 April eight Betty bombers, acting as hosts for the oka glide bombs, sortied to attack the American fleet. Before they could be shot down, six of the eight successfully released their oka bombs. One of the host bombers which returned to its base reported that the oka piloted by Lieutenant Junior Grade Saburo Doi had successfully impacted into an American ship. Although forty oka glide bombs were released during the Battle for okinawa, the only verified sinking by one of the human-guided missiles was the destroyer M.A. Able. 186

During the Battle for okinawa the last superbattleship, Yamato, sortied to its death. Yamato was caught on 6 April 1945 as the Japanese aerial armadas attacked the American fleet. The massive battleship was attacked by no fewer than 280 American carrier bombers. Like Musashi, the Yamato endured enormous damage, but eventually torpedoes

\footnotetext{
${ }^{186}$ Hata and Izawa, Japanese Naval Aces, 228.
} 
capsized her. Yamato did not sink alone. A light cruiser and four destroyers were also sunk by the attacking American aircraft. Radar had no role in the demise of the Yamato other than to provide intelligence for the Avenger acting as an aerial command ship for the attack. 187

The fanatical opposition encountered by the American forces at okinawa also led to the final solution to the war. President Harry S. Truman, authorized the use of a new weapon which had been secretly developed in the physics laboratory. On 6 August 1945, three B-29 bombers flew over the city of Hiroshima. One of the bombers, the Enola Gay, released a single bomb, and the city of Hiroshima ceased to exist. Three days later, on 9 August 1945, the three-plane mission was repeated over the city of Nagasaki. Again, in a single burst of atomic energy, an entire city was effectively destroyed. Although a number of Japanese zealots wished to continue the war, even if it resulted in the total destruction of the island nation, Emperor Hirohito intervened and accepted the terms of unconditional surrender to save his nation from extinction. 188

\footnotetext{
${ }^{187}$ Pemsel, A History of War at Sea, 149.

${ }^{188}$ Ibid., 150.
} 
Chapter 11

Conclusion

Radar was one of the most rapidly developing technologies of World War II. It made its debut as a primitive electronic device which, as a passive weapon, gave its user a limited advantage to see in the dark and in inclement weather conditions. Unfortunately, humans are reluctant to adopt newly developed and unproven military technology. Because it was a radical, unproven technology, acceptance of radar was impeded by the slowness of military commanders in the field who preferred to use tried and proven tools of war. Fortunately, in World War II there were some forward-thinking officers who believed in the potential of the electronic marvel and sought to adapt radar for a combat role.

As the technology developed, new roles were discovered for the use of radar, each having a profound effect upon the prosecution of the war. Early warning radar could detect an approaching enemy in time for the user to prepare a defense; if not in time to defeat the enemy, then usually in time to blunt the attack. As the officers and men who used radar in the early warning role became proficient, radar's effect on 
the outcome of battle increased.

Airborne search radar greatly increased the range at which an enemy force could be detected. It also allowed an airplane which discovered an enemy force on the surface of the ocean to track that force without being endangered by defensive fighters. The most profound adaptation of air-tosurface radar was to team it with the radio altimeter which allowed an airplane to maintain a precise height above the surface of the ocean during nocturnal conditions. The innovative adaptation of radar within the Black cat squadrons of the South Pacific turned a slow, obsolete patrol flying boat into one of the most deadly and proficient weapons of the war.

Surface radar, when properly used, could affect the outcome of naval battles, but its acceptance within the fleet units was a slow process. The failure of surface radar was not due to the electronics but, in most cases, due to inept operation and, more specifically, the reluctance of the surface task force commanders to accept change. Even when radar was adapted to control the dual-purpose five-inch guns in surface and anti-aircraft combat, the human element was most often the cause of a battle being lost. In other actions, in spite of human error, radar provided the necessary edge to give the Americans an important advantage over their Japanese opponents. 
The introduction of the proximity-fused shell in late 1943 came just in time to affect profoundly the outcome of the air war in the Pacific. Radar fire control for antiaircraft defense gave the Americans an edge, but when combined with the proximity-fused shell, it gave them a lopsided advantage over their Japanese adversaries.

The most significant addition to the radar arsenal was the radar-equipped night fighter. The proximity-fused shell and radar-controlled anti-aircraft defense had forced the Japanese to turn to nocturnal attacks just about the same time that night fighters were reaching the fleet to thwart that threat. Here again, the reluctance of the commanders in the fleet to accept the night fighter delayed effective deployment of the weapon. But once the night fighters had been accepted, their contribution to the defense of the American task force elements was phenomenal. It was also ir the arena of the night fighter that radar technology achieved its most rapid development. In the beginning radar could only "see" three to four miles, but by the war's end, a night fighter could detect an enemy one hundred miles away .

Was radar an effective weapon? Without radar the American Navy would have been hard pressed to achieve any victory during the early years of the war. The Japanese held the advantage in superior aircraft, superior ships and 
superior combat tactics. During the early naval battles, the element of chance was the principal factor that determined the outcome of the battle, but radar provided a slight advantage for the Americans. In later battles, radar became an ever-increasing factor in determining the outcome of a naval engagement. By mid-war, radar was providing the submarines, PT boats, aircraft and surface ships with a significant advantage over the Japanese enemy.

No single weapon will win a war. Radar was a passive weapon. When used properly in combat it provided the American forces with a decisive advantage over the Japanese. Although radar may not have won the war, it certainly contributed as much as any other weapon in achieving victory in the Pacific. 
SELECTED BIBLIOGRAPHY

Agawa, Hiroyuki. The Reluctant Admiral: Yamamoto and the Imperial Navy. Translated by John Bester. Tokyo:

Kodansha International, 1979.

Allison, David K. New Eye for the Navy: The origin of Radar at the Naval Research Laboratory. Washington D.C.: Naval Research Laboratory, 1981.

Angelucci, Enzo, Palo Matricardi and Adriano Zannino, eds. The Rand McNally Encyclopedia of Military Aircraft 1914-1980. New York: The Miltary Press, 1980.

Barker, Richard, John Weal and Elke Weal. Combat Aircraft of World War Two. New York: Mac Millan, 1977.

Blair, Clay Jr. Silent Victory: The U.S. Submarine War Against Japan. Vol. 1. Philadelphia: J.B.Lippincott, 1975 .

- Silent Victory: The U.S. Submarine War Against Japan. Vol. 2. Philadelphia: J.B.Lippincott, 1975.

Botting, Douglas, et al., eds. Epic of Flight: The Giant Airships. Alexandria, VA: Time-Life Books, 1981.

Breuer, William. Devil Boats: The PT War Against Japan. New York: Jove Books, 1988.

Chohen, Stan. East Wind Rain: A Pictorial History of the Pearl Harbor Attack. Missoula, MT: Pictorial Histories Publishing Company, Inc., 1981.

Cressman, Robert J. and Steve Eving. "A Glorious Page in our History": The Battle of Midway $4-6$ June 1942. Missoula, MT: Pictorial Histories Publishing Company, Inc., 1990.

Davis, Larry and Dave Menard. P-61 Black Widow in Action: Aircraft Number 106. Carollton, TX: Squadron/Signal Publications, Inc., 1990. 
Dower, John W. War Without Mercy: Race and Power in the Pacific War. New York: Pantheon Books, 1986.

Enright, Joseph F., Capt., USN, and James W. Ryan. Shinano: The Sinking of Japan's Secret Supership. New York: St. Martin's Press, 1987.

Fock, Harold. Fast Fighting Boats 1870-1945: Their Design, Construction and Use. Annapolis: Naval Institute Press, 1973 .

Fuchida, Mitso, Capt., IJN, and Masatake okumiyu, Cmdr., IJN. Midway: The Battle that Doomed Japan. Edited by Clarke H. Kawakami and Roger Pineau. New York: Ballatine Books, 1958.

Gardiner, Robert, ed. director, et al., eds. Conway's, All the Worlds Fighting Ships, 1922-1946. Greenwich, England: Conway Maritime Press, 1980.

Garfield, Brian. The Thousand Mile War: World War in Alaska and the Aleutians. Garden City, NY: Doubleday, Inc., 1983 .

Gunston, Bill, ed. The Illustrated History of Fighters. New York: Exeter Books, 1983.

Hansen, Chuck. USS San Francisco (CA-38): A Technical History. Missoula, MT: Privately printed, 1978.

Hamilton, John, et al., eds. War at Sea 1939-1945. Dorset, England: Blanford Press, 1986.

Hara, Tameichi, Capt., IJN. Japanese Destroyer Captain: Pearl Harbor, Guadalcanal, Midway-the Great Naval Battles of the Pacific as seen through Japanese Eyes. In collaboration with Fred Saito and Roger Pineau. New York: Ballantine Books, 1961.

Hata, Ikuhiko and Yasuho Izawa. Japanese Naval Aces and Fighter Units in World War II. Translated by Don Cyril Gorham. Annapolis: Naval Institute Press, 1989.

Honan, William H. Visions of Infamy: The Untold Story of how Journalist Hector C. Bywater Devised the Plans that led to Pearl Harbor. New York: St. Martin's Press, 1991.

Hough, Richard. The Longest Battle: The War at Sea 1934-45. New York: William Morrow and Company, Inc., 1986. 
Hoyt, Edwin P. Blue Skies and Blood: The Battle of the coral Sea. New York: Paul S. Erickson, Inc., 1975.

- Japan's War: The Great Pacific Conflict 1853-1952. New York: McGraw-Hill, 1986.

- The Lonely Ships: The Life and Death of the U.S. Asiatic Fleet. New York: David McKay Company, Inc., 1976 .

Ienaga, Saburo. The Pacific War: World War II and the Japanese 1931-1945. New York: Pantheon Books, 1978.

Ike, Nobutaka, ed. Japan's Decision for War: Records of the 1941 Policy Conferences. Stanford: Stanford University Press, 1967.

Jablonski, Edward. Airwar: Outraged Skies. Vol. 3. Garden City, NY: Doubleday \& Company, Inc., 1971.

- Epic of Flight: America in the Air War. Alexandria, VA: Time-Life Books, 1982 .

Knott, Richard c., Capt., USN. Black Cat Raiders of WW II. Annapolis: The Nautical \& Aviation Publishing Company of America, 1981 .

- The American Flying Boat: An Illustrated History. Annapolis: Naval Institute Press, 1979.

Lewin, Ronald. The American Magic: Codes, Ciphers and the Defeat of Japan. New York: Penguin Books, 1983.

Lundstrom, John B. The First Team: Pacific Naval Air Combat from Pearl to Midway. Annapolis: Naval Institute Press, 1984 .

Musicant, Ivan. Battleship at War: The Epic Story of the USS Washington. New York: Harcourt Brace Jovanovich, 1986.

Pemsel, Helmut. A History of War at Sea: An Atlas and Chronology of Conflict at sea from Earliest Times to the Present. Translated by D.G. Smith, Major. Annapolis: Naval Institute Press, 1975.

Prange, Gordon w. At Dawn We Slept: The Untold Story of Pearl Harbor. With the collabcration of Donald $M$. Goldstein and Katherine V. Dillon. New York: McGraw Hill, 1981. 
Donald M. Goldstein and Katherine V. Dillon. December 7, 1941: The Day the Japanese Attacked Pear1 Harbor. New York: McGraw Hill, 1988.

Donald M. Goldstein and Katherine V. Dillon. Miracle at Midway. New York: McGraw Hill, 1982.

Rearden, Jim, Cracking the Zero Mystery. Harrison, PA: Stackpole Books, 1990.

Reynolds, Clark G., et al., eds. The Epic of Flight: The Carrier War. Alexandria, VA: Time-Life Books, 1967.

Rusbridger, James and Eric Nave. Betrayal at Pearl Harbor: How Churchill lured Roosevelt into World War II. New York: Summit Books, 1991.

Sherry, Michael. The Rise of American Air Power: The Creation of Armageddon. New Haven: Yale University Press, 1987.

Spector, Ronald H. Eagle Against the Sun: The American War with Japan. New York: Free Press, 1985.

Stewart, Adrian. The Battle of Leyte Gulf. New York: Charles Scribner's Sons, 1979.

Tillman, Barrett. Avenger at War. Annapolis: Naval Institute Press, 1990.

- Corsair: The F4U in World War II. Annapolis: Naval Institute Press, 1979.

- Hellcat: The F6F in World War II. Annapolis: Naval Institute Press, 1979.

Tolard, John. Infamy: Pearl Harbor and its Aftermath. Garden City, NY: Doubleday, 1982.

Ugaki, Matome. Fading Victory: The Diary of Admiral Matome Ugaki 1941-1945. Edited by Donald M. Goldstein and Katherine V. Dillon, trans. Matsataka Chihaya. Pittsburgh: University of Pittsburgh Press, 1991.

Weal, Elke C., John A. Weal and Richard F. Barker. Combat Aircraft of World War II. New York: MacMillan, 1977.

Winterbotham, F.W. The Ultra Secret. New York: Dell Publishing Co., Inc., 1974. 
Y'Blood, William T. Red Sun Setting: The Battle of the Philippine Sea. Annapolis: Naval Institute Press, 1981. 